Andrews University

Digital Commons @ Andrews University

1981

\title{
Toward a Theology of Christian Worship and the Improvement of Worship Participation in Seventh-day Adventist Churches in Africa
}

Andre H.M. Stijnman

Andrews University

Follow this and additional works at: https://digitalcommons.andrews.edu/dmin

Part of the Practical Theology Commons

\section{Recommended Citation}

Stijnman, Andre H.M., "Toward a Theology of Christian Worship and the Improvement of Worship Participation in Seventh-day Adventist Churches in Africa" (1981). Professional Dissertations DMin. 644. https://dx.doi.org/10.32597/dmin/644

https://digitalcommons.andrews.edu/dmin/644

This Project Report is brought to you for free and open access by the Graduate Research at Digital Commons @ Andrews University. It has been accepted for inclusion in Professional Dissertations DMin by an authorized administrator of Digital Commons @ Andrews University. For more information, please contact repository@andrews.edu. 


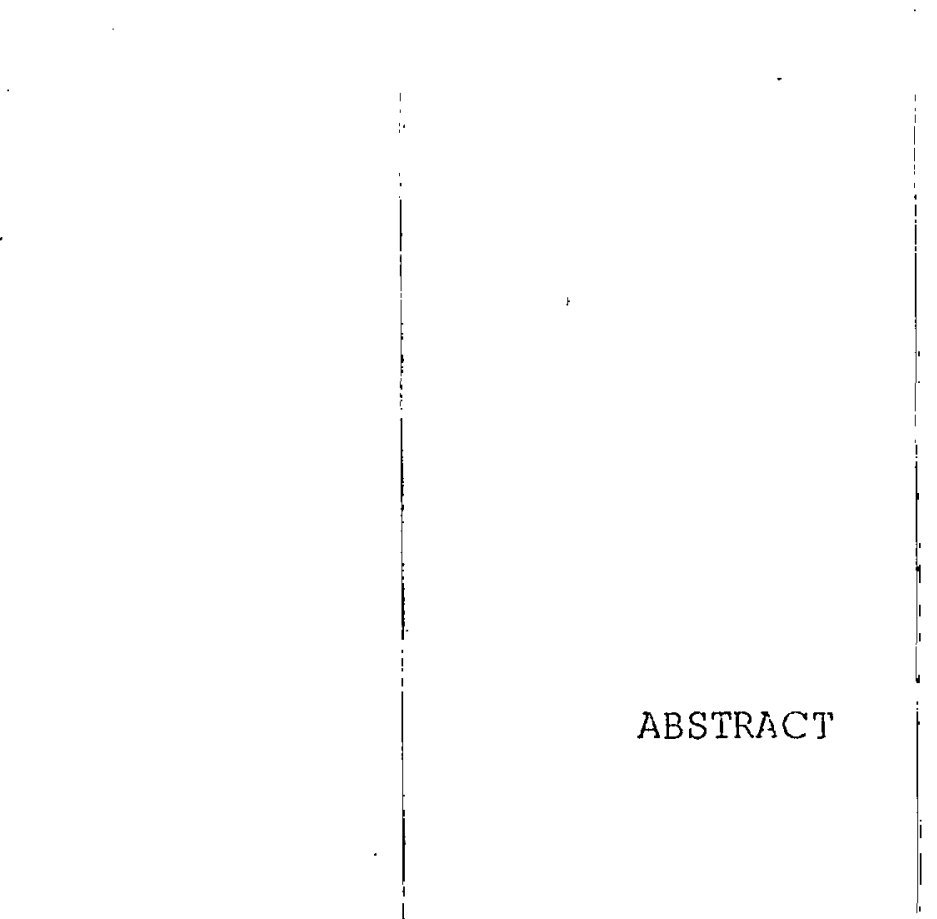

TOWARD A IIHEOLOGY OF CHRISTIAN WORSHIP AND THE IMPROVEMENT OF WORSIJIP PARTICIPATION

IN SEVENTH-DAY ADVENTIST CHURCHES

IN AFRICA

by

André H. M. Stiprmán

Chairman: Arnold A. Kurtz 


\section{Project Report}

Andrews University

Seventh-day Adventist Theological Seminary

TITLE: TOWARD A THEOLOGY OF CHRISTJAN WORSHIP AND THE IMPROVEMENT OF WORSHIP PARTICIPATION

IN SEVENTH-DAY ADVENTIST CHURCHES

IN AFRICA

Name of researcher: André H. M. Stijnman

Name and degree of faculty adviser: Arnold A. Kurtz, Ph.D., D. Min. Date completed: Jüne 1981

In the typical mission station in West Africa in the nineteenth and even in the early twentieth century, life was routinely patterned after the Western mode, hardly reflecting at all the life and routine of the surrounding villages. This was particularly true of their vorship. It is the thesis of this doctoral project that an effective approach to promoting and advancing African Christianity is to proclaim the basic principles of Christian worship and faith in such a way that these principles can be understood and lived in any 
society or culture. Christian worship must be seen as transcending ethnic and cultural barriers.

It was the purpose of this project to introduce these basic principles of worship to the student body and faculty of the Adventist Seminary of West Africa. This school was viewed as having the potential to play a key role through its graduates in influencing the worship patterns of the church in Africa.

An extensive statement of a theological nature was prepared as a position paper on worship and constitutes the first part of this report. The practical application of the implications stemming from this statement is reported in the second part of this paper. Certain key concepts are extrapolated from the position paper as the basis for a program of education for worship. Recommendations for incorporating such a program at A.S.W.A. included preaching (as at a student Week of Spiritual Emphasis), the formation of a worship committee, a worship seminar/workshop, Bible-study groups, and a prayer-meeting study series.

The first steps in the implementation of such a program were taken in a Week of Spiritual Emphasis during which twelve sermons on the subject were presented. The activities of this special week are reported, evaluated, and analyzed in this report. 


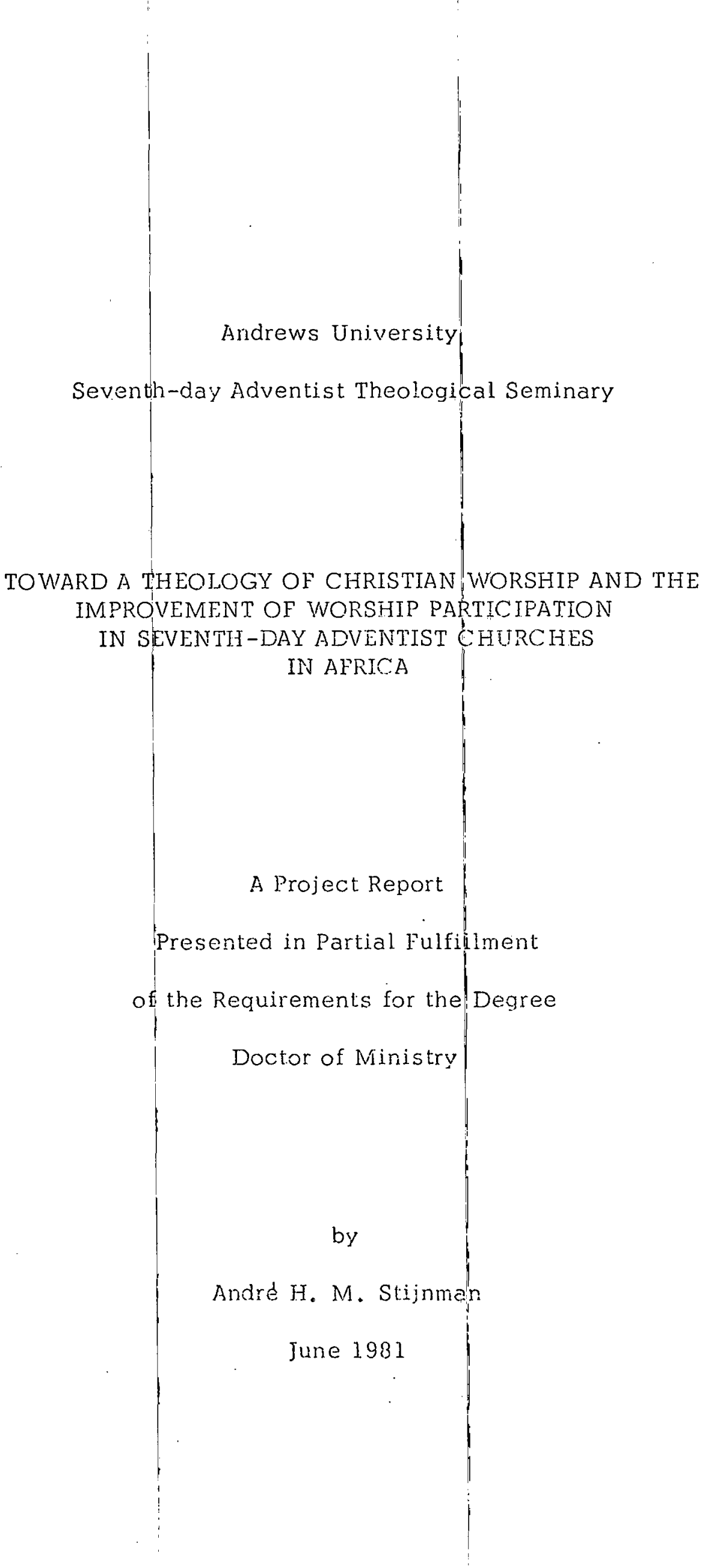




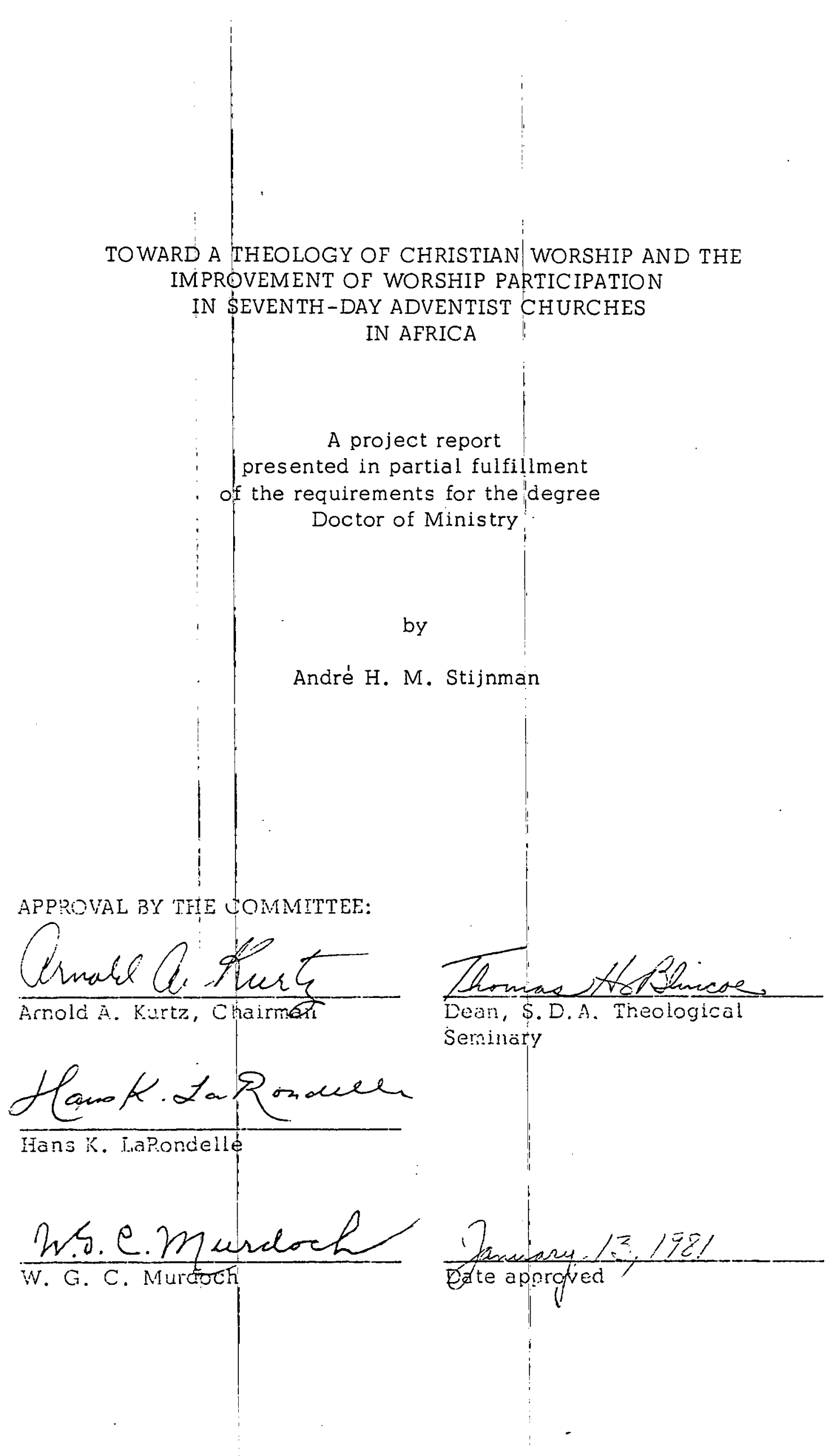




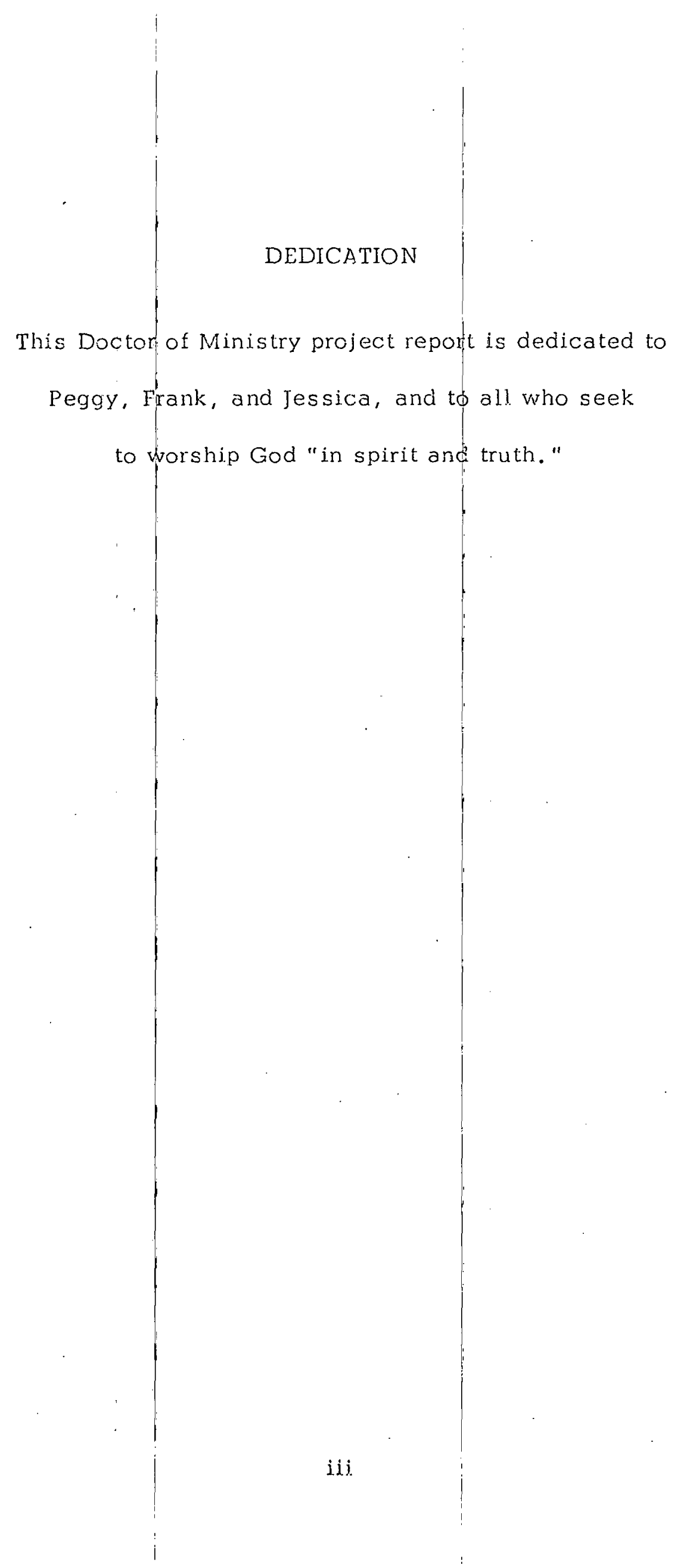




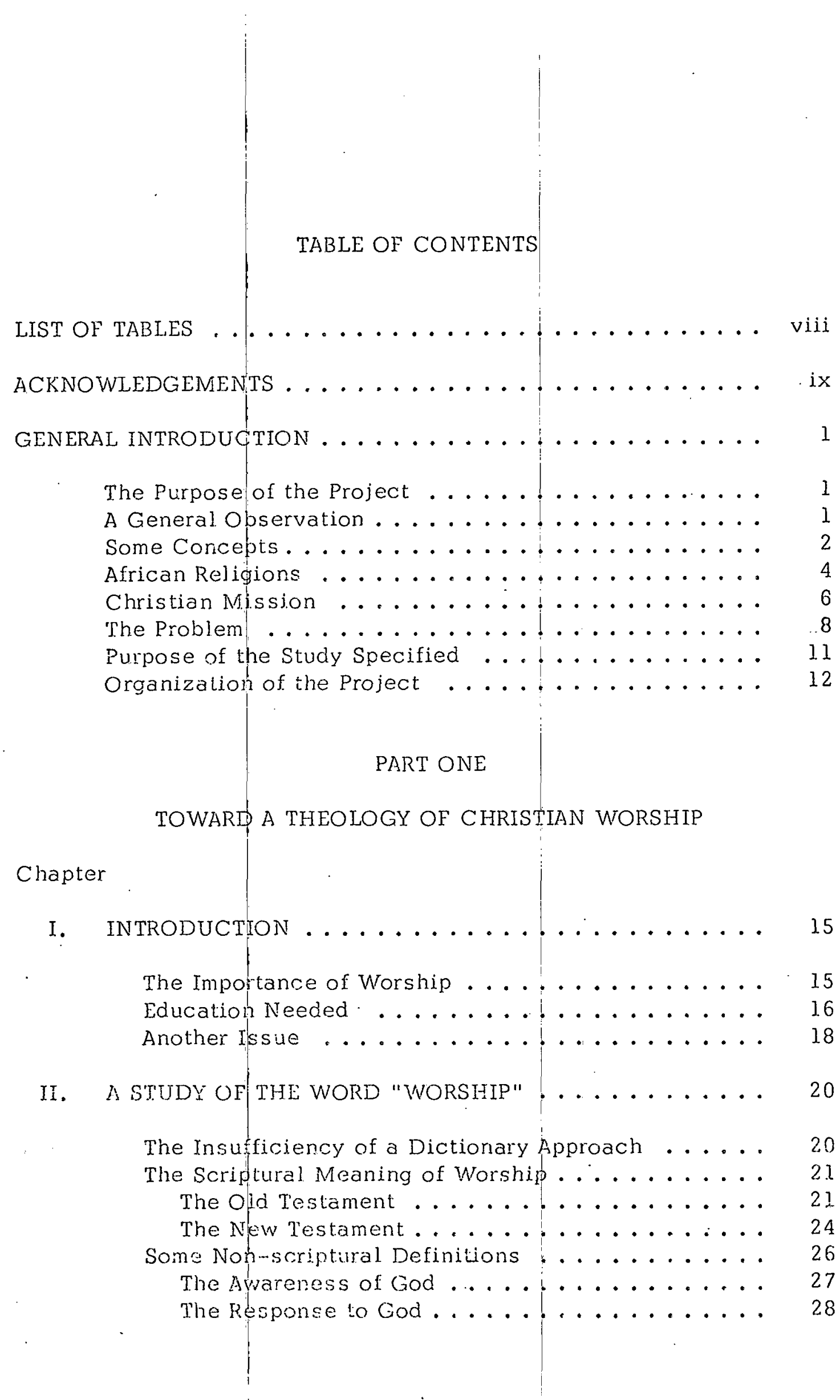


Worshipland Liturgy ............... 89

Worship, Liturgy, and Apostolicjty......... 92

v. WORSHIP AND SABBATH: A RECIPROCITY ........ 96

Introduction $\ldots \ldots \ldots \ldots \ldots$

God Hallowed the Seventh Day . . . . . . . . . . 96

Man Partakes of Holiness ..... . . . . . . . . . 100

The Culmination of Worshipful Life: Sabbath ..... 104

Sabbath Holiness Permeates the Total Life...... 106

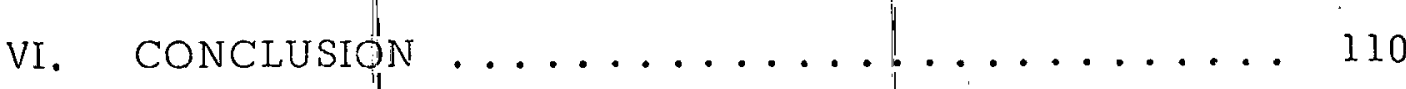

VII. INTRODUCTION ........................ 114

Statement of the Probiem ...................... 114

Short History of A. S.W.A. ............. 115

Description of the 1972 Student Body ........ 116

Goals of A.S.W.A. ............... 13.7

Religious Life at A.S.W.A. ........... 117

The Potchtial Role of A.S.W.A. for the Improve-

ment of the Worship Situation $\ldots \ldots \ldots \ldots$

Education in Worship is Essential .......... 119

Potential Impact and Effect of Worship Education

in West African Adventist Churches ....... 121

Approaches to Education for Worship.......... 122

VIII. A PROGRAM OF EDUCATION IN WORSHIP PRINCPLES FOR A.S.W.A. STUDENTS ............. 126

Theological Undergirding . . . . . . . . . . . . 126

Recommendations .................. 128

A Worship Cornmittee ............. 128

Purpose of the committee . . . . . . 128

Members of the cormmittee $\ldots \ldots \ldots \ldots \ldots$ J. . . 28

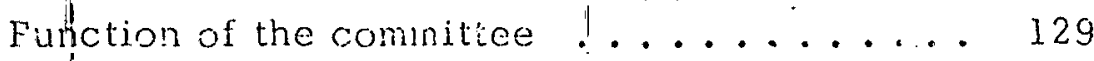

Worship Seminar/Workshop . ......... 130

Methods for conducting a seminar/workshop . . 130

Bible--study Groups ............... 133

Worship Priyer-Mieeting Series . . . . . . 135 
A Week of Worship Emphasis............ 137

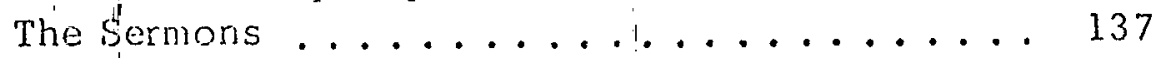

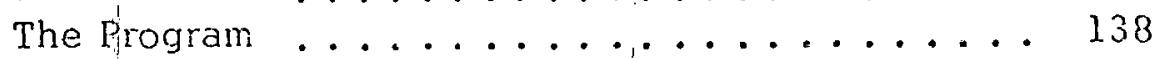

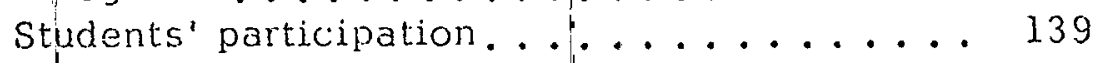

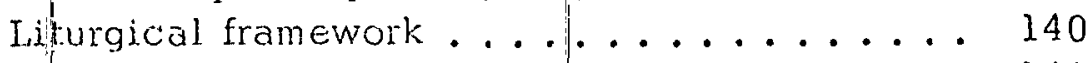

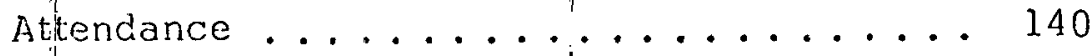

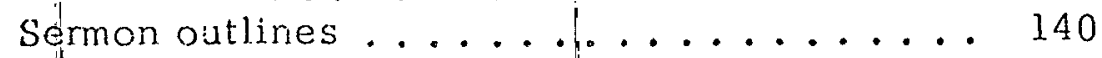

Results oi the Worship Emphasis Week ....... 145

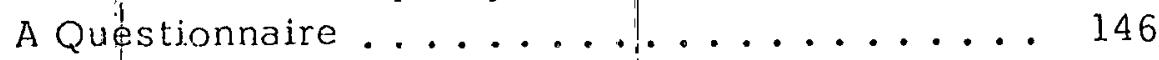

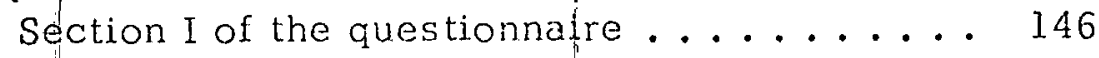

Section II of the questionnaire ....... 147

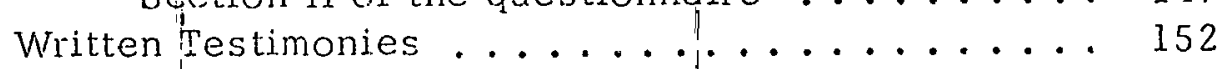

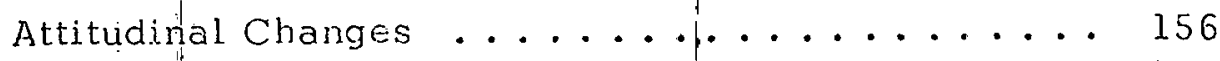

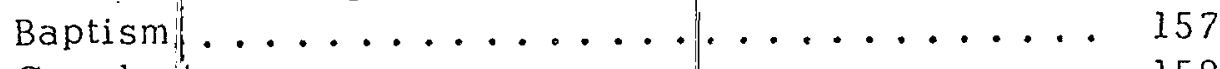

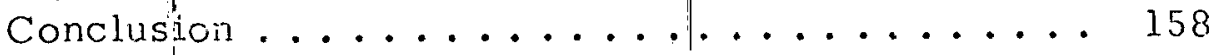

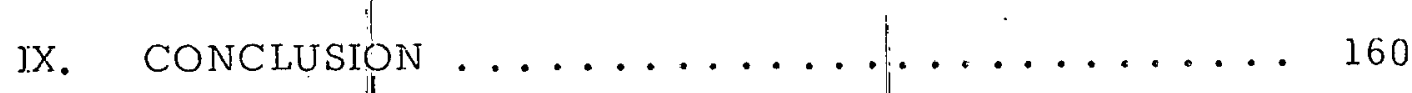

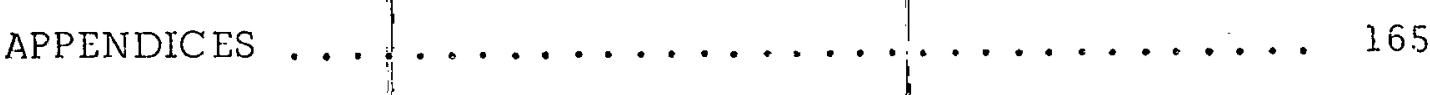

APPENDIX A: A Letter to the A.S.W.A. Religion

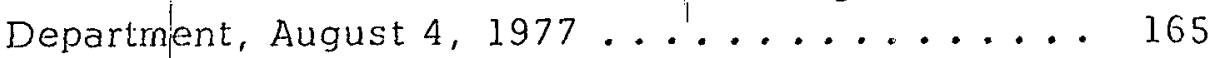

APPENDIX $\mathrm{B}$ : The Response of the A. $\mathrm{S}$. W. A.

Executive Board, October $6,1977 \ldots \ldots 167$

APPENDIX $\$$ : The A.S. W.A. Week of Spiritual

Emphasils Program, February 12-18, 1978...... 169

APPENDDX D: Sermon Outlines: Week of Worship

Emphasi.s, A.S.W.A., February 12-18, 1978 .... 173

APPENDIX E: A Questionnaire Distributed on

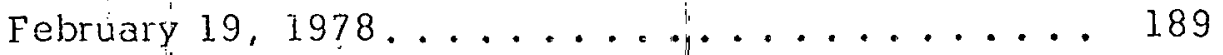

APPENDX

Emphasils by the Principal of A.S.W.A. ...... 191

APPENDIX G: Requests for Baptism by Non-

Adveritist. A.S.W.A. Students after the Worship

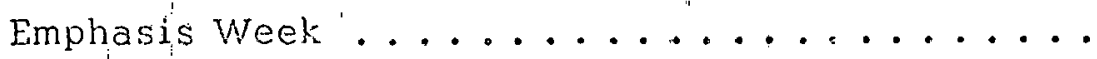

BIBLIOGRAPHY $\ldots \ldots \ldots \ldots \ldots$

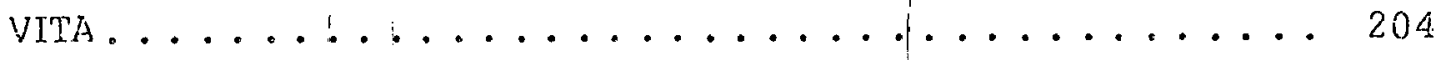




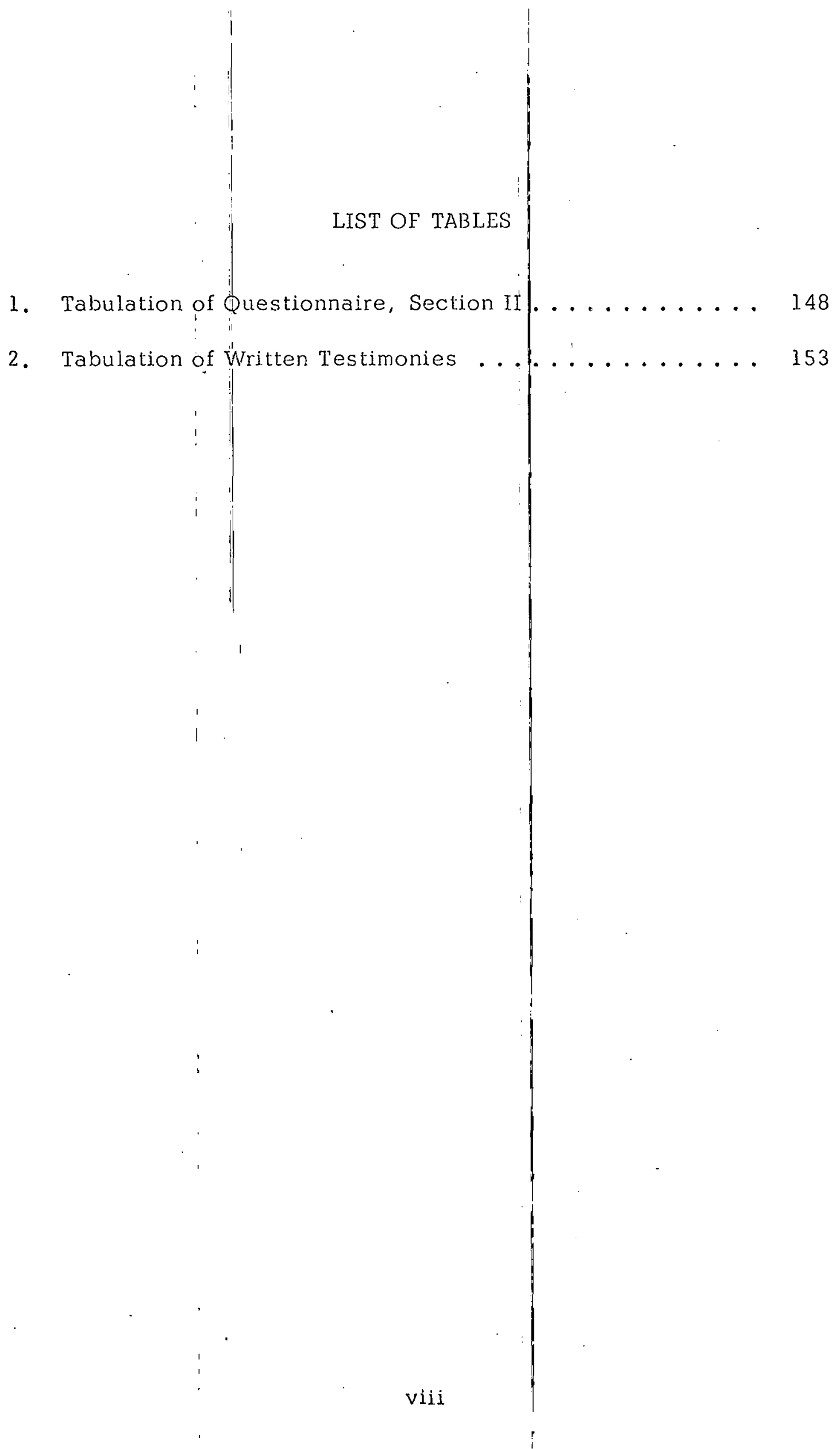



fact that it required frequent absences from home,

Finally, I do thank the Lord, my Saviour, for His guidance and grace in this study in and the practice of Christian worship. He enabled me to gain a new vision of a prime motivation for mission in this world. It is my hope, therefore, that this project may function as a tool for further search into the deeper meaning of and an improved participation in that worship which is

"in spirit and truth!" 


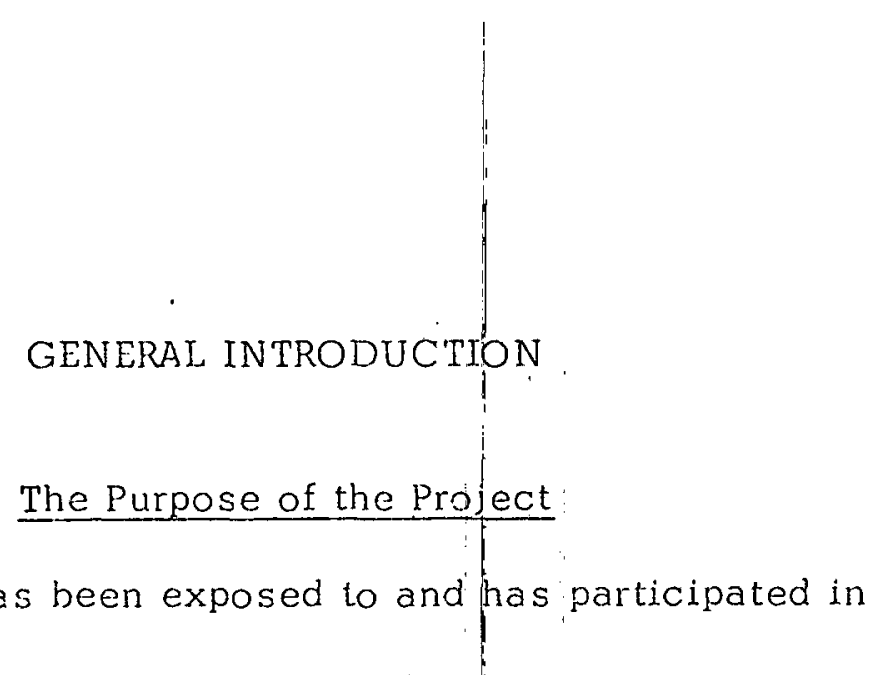

Seventh-day Adventist worship for more thanitwenty years certain questions come to mind: "Why do Adventists go to church?" and "What is their motive for going to church?" When one leads out in many worship services and in the missionary outreach of the church, one becomes aware of other thought-provoking questions: "Why do God's people behave as they do in worship Services?" and "Why is their behavior in church often so different from their behavior in society?" "Why do only a few members enter into missionary work after the worship service is over?"

These and many other questions bring to attention the center of the Christian's life, namely, worship. Through intensive reading and serious study one searches for answers to questions like the ones just mentioned. This project is the result of years of reading, ministering, and lecturing.

\section{A General Observatión}

ihe sources which were consulted on Christian worship deal with congregational worship; almost nothing/discusses personal 
worship. Therefore, the report refers most frequentily to and quotes from sources which explain Christian worship in terms of congregational worship.

However, the principles of Christian worship, or worship in general, underlying congregational worship are equally applicable to the personal worship of the individual Christian believer who is a member of the congregation. If there were no individual believer. there would be no church. A church presupposes that there are individual members and from this follows that congregational worship presupposes individual. worship. This observation needs to be taken into consideration when reading Part One of the project report.

\section{Some Concepts}

The reading for the report bore out that worship is a most important phenomenon in human existence, because man "is by nature religious and must have some object of worship." 1 Thus man is called the Homo Religiosus, and the student fof worship is, in reality, engaged in a search for the esse of life. People on earth, from ancient times up to the present were and are worshipers in one way or another. Worship is universal. Describing, from a phenomenological perspective, the African peoples, their life styles, work, and behavior in their societal, cultural, and religious setting, John S. Mbiti states:

IFrankin M. Segler, Christian Worship: Its Theology and Practice (Nashville, Tennessee: Broadman Press, 1967), p. 13. 
Where the individual is, there is his religion, for he is a religious being. It is this that makes Africans so religious: religion is in their whole system of being . . . to live is to be caught up in a religious drama. 1

History shows that right from the beginning man worshiped some object(s). But although the Homo Religiosus idea is recognized within Christianity, it is not the motive for Christian worship. The Christian has a completely different answer to the question "Why worship?" His answer is theological and eschatological. He worships because "of. what God has done and is doing and will do through His Son and through His Spirit." 2

The chief aim of Christian worship is to thank God and to praise Him name and thus to enter into a definite experience with God. Thus worship is most important. Jean-jacques von Allmen, explaining the relationship between church and worship, expresses the importance of worship as follows:

Worship is one of the two essential elements in the life of the Church (the other being the evangelization of the world). Hence, just as it is possible to say: the Church spells missionary activity, so it is possible to say: the Church spells worship. For the Church has an inevitable two-fold orientation---towards God in its worship, and towards the world in its apostolate. 3

IAfrican Religions and Philosophy (London: Heineman Educational Books Ltd., 1975), p. 3.

2John H. Tietjen, "Worship and the Life of the Church," Concordia Theological Monthly 43 (March 1972):145.

${ }^{3}$ Worship: Its Theology and Practide (New York: Oxford University Press, 1965), p. 283. 
The inference can be drawn that if the church fails in its worship, it will also fail in its mission. In such a case, the church has degenerated into a "social club, or settlement, or lecture bureau." 1

Conversely, in order to improve the' church's missionary activities, it is necessary to reform its worship, not the worship liturgy of the church, but, principally, its concept of worship.

Before an attempt is made to presen't a word study and a theology of Christian worship, it must be stated that the practical part of this project was implemented at the Adventist Seminary of West Africa. It is proper, therefore, to relate briefly some aspects of the African religions and the mission of the Christian Church in West Africa.

\section{African Religions}

African religions are a spiritual patrimony developed by the genius of the people of Africa in the course of its history. They are also a clear manifestation of a religious endowment inherent within human nature. From the religious-historicalview it can be said that African people lived--and many are still living--close to nature where the 'mysterious' forces confront them in their daily life. Africans were--and still are--used to constantly seeking to be on good terms

${ }^{1}$ George Walter Fiske, The Recovery of Worship (New York: The MacMillan Company, 1931), p. 18. 
with the supernatural or superhuman powers (gods) who inhabit the forest, the caves, the rivers, or the mountains, who control the crops, and who determine success or failure in hunting. It is stated:

The important thing in African religion is that every act of daily life has religious significance because through it one, may either maintain good relations with the gods or offend them with possibly disastrous results. 1

The African, then, is a "religicus being" and religion "is in their whole system of being." The African "lives in a religious universe." 2 The typical African does not live unto himself; he is an integral part of his particular tribe. From the day he is born, the tribe takes precedence over his own individual de sires and aspirations. Thus, what the tribe does, he does, and what the tribe believes, he believes. Each tribe has its gods and beliefs and thus we discover almost as many religions as there are tribes in the African continent. The mentality of the African is molded by thousarids of years of religion. The gods that are worshiped by his tribe, he worships. It is this mentality which dictates the individual's expression of the faith that is in him. It is also this mentality that animates the traditional religions. Africans who practice their traditionai religions and give

IJohn and Rena Karefa-Smart, The Halting Kingdom (New York: Friendship Press, 1959), p. 9. 2 Mbiti, pp. 3 and 15.

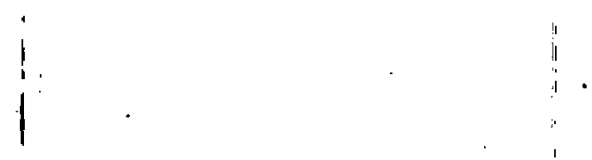


expression to their religjous forms are called "animists." 1 It is recognized that the animists in Africa outnumber those on other continents. It is estimated that there are about $80-120$ million animists in Africa alone, while in the rest of the world the estimated figure seems to be about 30 million. The estimate for West Africa, including Nigeria, is $38,085,000 .^{2}$

\section{Christian Mission}

The earliest introduction of the Christian gospel to transSahara, animist Africa was by the chaplains who accompanied Portuguese merchant sailors in the fifteenth century. The world-famed bronzes of Benin in Nigeria depict Euorpeanș wearing Christian crosses. These bronzes date back at least five centuries.

The slave trade of the seventeenth and eighteenth centuries caused a decimation of the African population. It is believed that whatever churches had been established before that time did not survive the slave trade. It was in 1787 that Christianity was reintroduced to some parts of West Africa by returning slaves, one of which was Zachary Macaulay. This African Christian, a member of the Church of England Chapham sect, led the first group of freed slaves to the newly acquired haven in Sierra Leonein 1787. But Christianity ed. Confessing Christ in Different Cultures

(Bossey, Swritzerland: World Council of Churches, 1977)

${ }^{2}$ Secretariat for Non-Christians, Meeting the African Religions (Roma: Libreria Editrice Ancora, 1968), p. 15. 
did not reappear in most of trans-Sahara Africa until the great Protestant missionary revival which led to the formation of the Baptist Missionary Society (1792) and the London Missionary Society (1795). Since that time Africans have assisted in the spreading of the gospel. Samuel Adjai Crowther started the Christian mission in the Niger Delta in Nigeria in the third decade of the nineteenth century. He became the first post-medieval African to become a Christian bishop. Other African Christians accompanied European government officials and traders to all parts of Africa as clerks and agents. They were often the nucleus of Christian congregations through which the surrounding tribes vere evangelized. This took place in the nineteenth century. 1

Although Christian missions were well established in West Africa by the end of the nineteenth century, it was not until 1914 that the Seventh-day Adventist Church began its mission work in Nigerja when D. C. Babcock preached the gospel there. It was not solely by means of public evangelism that the Seventh-day Adventist. Church expanded so rapidly in this part of the African continent; the Adventist missionaries and evangelists recognized that in addition to public evangelism there needed to be a program to reach the younger minds of Africa. They erected schools and began to teach and educate.

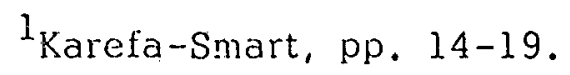


The Problem

In the typical mission station in West Africa in the nineteenth and even: in the early twentieth century, the routine of life was usually patterned after the life the missionaries were accustomed to in their own country. It reflected very little of the African life which was lived in the surrounding villages. The case was the same with their worship:

As the patterns of worship were alli foreign, very little opportunity was given to the new converts to express their religion in familiar ways. Songs and hymns and choruses were painfully transliterated almost word for word and phrase by phrase from the English or other European language hymnals. The same was true for prayer books and catechisms, 1

Differently stated, the Christianity which was brought to

Africa was wholly the "Western Church" type of Christianity. Western Europe had acquired the energy to transform the world in part from that spirit of Christianity which thrives to incorporate itself in humanity. Generally speaking, however, western Christianity was still regarded as an instrument of domination in the endeavor to renew the face of the earth. But Aylward Shorter correctly observes that "one cannot include colonization, the spread of Western capitalism, and the imposition of Western language and culture in this movement of Christian worid renewal. "2

$$
1_{\text {Karefa-Smart, p. } 19 .}
$$

${ }^{2}$ African Christian Theology (Gateshead, Great Britain: Northumberland Press Lid., 1975), p. 22. 
Indeed, the Christian Church in Africa has often been identified as a means for spreading imperialism and capitalism. It is illuminating as well as painful to refer to an example of negative reaction to Westorn Christianity. During the early days of the nationalist movement in Nigeria, followers of one national leader borrowed wholesale Western Christian hymns, creeds, and prayers, and merely substituted the name of the national leader where the name of Christ appeared. 1

There are students at the Adventist Seminary of West Africa today who still identify Christianity as the "white man's religion." They also uphold the observation that "African Christians remain in the shackles of a 'White Church,' in the grip of forces that are not of their own making. 2

The "white man's religion" must be changed into "African Christianity." Pope Paul VI declared this in his closing speech of the first Pan-African meetings of Roman Catholic bishops at Kampala, Uganda, in 1969. During the course of his speech he said:

An adaptation of the Christian life in the fields of pastoral, ritual, didactic and spiritual activities is not only possible, it is even favoured by the Church. The liturgical renewal is a living example of this. And in this sense you may, and you must, have an African Christianity. Indeed you possess human vaiues and characteristic forms of culture which can rise up to perfection so

\footnotetext{
l'Karefa-Smart, p. 20.

${ }^{2}$ Shorter, ibid.
} 
as to find in Christianity, and for Christianity, a true superior fullness and prove to be capable of a richness of expression all of its own, and genuinely African. ${ }^{l}$

already been made in various parts of Africa to use African music art already been made in various parts of Africa to use African music, art, architecture, and traditional ways of worship in Christian churches. For example, African tunes were in use in hymn books in Nyasaland around 1920. The overall picture, on the other hand, is that in Africa a Christian Church has been created which has culturally, organizationally, and financially been kept in "bondage" to the white world. African Christianity will come only when people have stopped talking about translating Western Christianity into African terms and have begun talking about translating African Christian ideas into Western terms. ${ }^{2}$ As sol Jacob explains:

But we, who' confess Christ cannot make our witness relevant to and effective in the life of man unless we take account, without dismay, of the situation in which we find ourselves and what it means to confess Christ today. in the social and cultural conflicts that confront us and by which in any generation our task is defined. 3

Since man is a religious being and what has been described in the previous pages is the situation in Christian Africa, the question to be raised in the context of Christian worship is: "How, then, do

l"Closing Discourse to Ail-Africa Symposium, "Gaba Pastoral Paper No. 7, pp. 50-51; quoted in Shorter, p. 20.

2 Shorter, p. 22.

3 Mbiti, Confessing Christ, p. 69. 
we assist in promoting and advancing African Christianity?" One of. the most effectidy ineribs ito that end 15 .to simply preach the principles of Christian worship and faith in such a way that these principles can be understood and lived in any society, any culture, any tribe, and any nation (cf., Rev 14:6). In other words, Christian worship as the center of life is an issue of primary importance and transcends ethnic and cultural barriers, while the form of Christian worship, as expressed in church buildings and worship forms, is secondary and subject to the culture in which the worship takes place.

\section{Purpose of the Study Specified}

The purpose of this study, then, is to introduce and explain the Scriptural principles of Christian worship to men and women of West Africa who attend the Adventist Seminary of West Africa (A.S.W.A.). The emphasis is not on the one-hour worship service on Sabbath morning but on the why-ness of worship in the life of the Christian believer in general so as to encourage greater worship participation. In the course of this program of worship education it will be understood that the form of any particular worship service--the how-ness of Chistian worship, or its liturgy in the narrow sense-whether that form is Western or African is of secondary importance. It is hoped that these A.S.W.A. students will reassess Christian worship in such|a way that they will understand it as a spontaneous expression of their religious experience in the daily Christian life. 


\section{Organization of the Project}

The fundamentals of Christian worship which were touched upon in the previous pagcs are elaborated upon in this project report. Part One of the project involves the study of the word "worship." From this discussion it becomes obvious that a word study alone cannot provide the satisfactory answer to the question, "What is Christian Worship?" (chapter II).

In chapter III an attempt is made to present a theology of Christian worship in a systematic manner. A theology, a soteriology, an ecclesiology, a missiology, and some other approaches to worship are developed in order to explain the why-ness of Christian worship. Chapter IV draws attention to the biblical meaning of leitourgia and describes the relationship between worship and liturgy in the wider sense of the word.

Chapter $V$ presents an explanation of the relationship which exists between Christian worship and the Sabbath, while in the last chapter (VI) of this part a conclusion is drawn from the materials which have been discussed in the previous chapters.

Part Two describes how the theological principles of Christian worship were presented to the students of the Adventist Seminary of West Africa during the week of worship emphasis in 1978.

After a description of the history of A.S.W.A., the 1978 student body, and the is sue that education in worship is essential in the Christian lifo (chapter VII), the paper moves into a discussion in 
chapter VIII of a possible program of education in public worship for A.S.W.A. as well as a description of an actual week of worship emphasis which was conducted there.

An analysis is presented from which the conclusion is drawn that the worship emphasis week seemed to have been a suc-. cessful endeavor in helping the students toreassess the principles of Christian worship.

The final chapter (IX) contains some conclusions which are drawn from information the students provided. This project strengthens the concept that when God's people worship Him more intelligently, the effects of such a worshipful Christian life will not be without results; the church will grow more rapidly in quantity as well as quality. 
PART ONE

TOWARD A THEOLOGY OF CHRISTIAN WORSHIP 


\section{INTRODUCTION \\ The Importance of Worship}

The general observations already mentioned ${ }^{l}$ show that worship ought to be a main concern of the Seventh-day Adventist Christian. Moreover, at the heart of the gospel message, which the Christian proclaims, inspired words are found: ". . worship him who made heaven and earth. . ." (Rev 14:7 $)^{2}$ Seventh-day Adventists are an apocalyptic and a prophetic people, who have the roots of their Christian existence in the prophecies of Daniel and of John the Revelator. Both these apocalyptic documents reveal that the essence of life is worship. 3 It is thus that worship is emphasized and it is shown that the conflict of the ages is essentially one regarding worship. 4

${ }^{1}$ See General Introduction.

${ }^{2}$ Unless otherwise indicated, all Scripture references are from the Revised Standard Version.

${ }^{3}$ Cf. Dăn 3:16-18;6:10;9:3-19; Rev 4:10;5:14.

${ }^{4}$ Heinrich Greeven, "proskuneo," Theological Dictionary of the New Testament (Grand Rapids: Wm. B. Eerdmans, 1964-1976), 6:764-765 (hereafter abbreviated TDNT). 
In the book of Daniel and in the Revelation to John the worship of God by heavenly beings is portrayed so that God's people may learn how to truly worship Him (e.g., Dan 7:10; Rev 4:10; 19:10). Right in the center of these inspired sources man is confronted with the invitation to worship the only true God. In the book of Daniel the divine appeal is made indirectly (Dan 7:8-14), while in the Revelation to John the appeal is very explicit: "Fear God and give him glory. . . and worship him. : ." (Rev 14:7).

Seventh-day Adventists have been called by God in grace (Rev 14:6) to be worshipers par excellence, thus demonstrating in their words and in their way of life what true worship means and how such worship is practiced.

Adventists are to be primarily a worshipful people. . . . Adventism . 1. . is not just a creed, and not a set of doctrines. (It) ... essentially is a way of life. And that way of life is a way of worship. 1

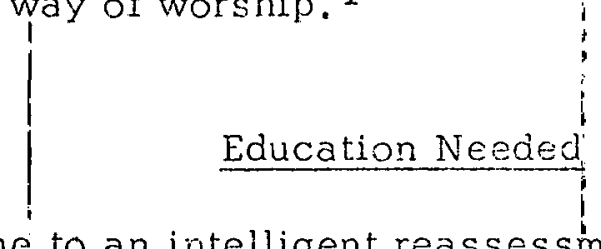

To come to an intelligent reassessment of Christian worship, education is necessary. An authority, emphasizing the urgency of such education, 'says that "renewal in Christian worship is best accomplished by . . . a n educational program. ... Education in A. L. Bietz, "Our Worship of God," The Ministry 31 ,October 1958): 47 . 
worship is essential and long overdue." l

Another well-recognized authority in Adventist worship shows her burden for the improvement of worship and the missionary activities of the Adventist Church.

Unless correct ideas of true worship and true reverence are impressed upon the people, there will be a growing tendency to place the sacred and eternal on a level with common thing's, and those professing the truth will be an offense to Gód and a disgrace to rel.igion. ${ }^{2}$

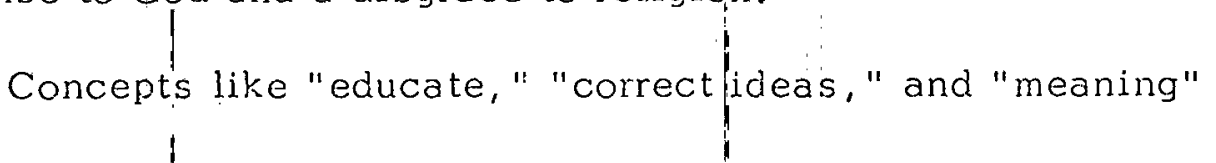

involve the exercise of man's mind. Worship may begin with an emotional response to God, but there comes a time when the emotional response has to be thought through and the concepts of Christian worship presented in a systematic way. When this procedure is followed Christian: worship is not just an emotional response but an intelligent worshipful reaction of the believer to the self-revealing God. Hence, worship ought to be the approach to God of the whole person. Since man is endowed with a mind he has the dity to exercise that mind. ${ }^{3}$

Through' educational development in the worship of God, the

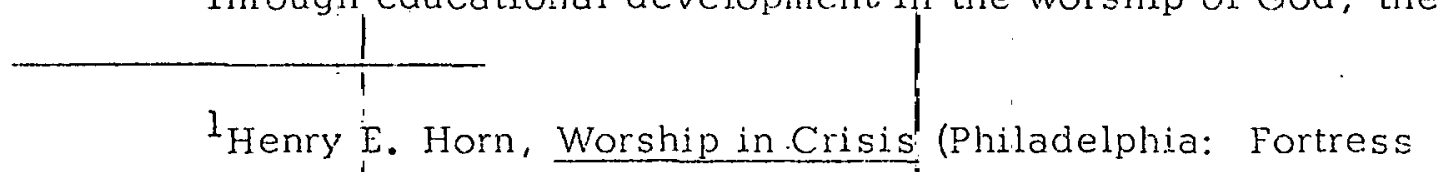

Press, 1972), pp! 144 and 153.

2 Ellen $G$. White, Testimonies for the Church, 9 vols. (Mountain View, Coôlif.: Pacific Press Pub.|Assn., 1948), 5:500.

${ }^{3}$ William Barclay, The Revelation of John, 2 vols. (Edinburgh:

The Saint Andrew, Press, 1975), 1:153. 
Through educational development in the worship of God, the Christian worshiper not only gains an increascd theological understanding of what worship is, but is simultaneously given the opportunity (i.e., grace) to intensify his participation in Christian worship. "The stronger our grasp becomes on the deeper meanings of Christian worship, the more we... enter into a 'rehearsal of the drama of our salvation.'"l It is imperative that we seek an intelligent understanding of what Christian worship is, ${ }^{2}$ because the how of such worship is determined by the why of Christian worship. In addition, the fact of what the church is must determine how worship is performed. 3

\section{Another issue}

Another question which needs to be answered is: "How does one know whether Christian worship as a human response is acceptable to God?" There is widespread experimentation going on in Christian worship. However, it must be realized that in the light of the divine revelation Christian worship involves consideration of God as well as of man. Realizing this, it is all the more important that

${ }^{1}$ Wilfred M. Baily, Awakened Worship (Nashville: Abingdon Press, 1972), p. 21.

${ }^{2}$ R. A. Anderson, "Effective Worship," The Ministry 37 (September 1964): 48 .

3 Tietjen, pp. 144, 149-150. 
"We establish a theological norm for the guiding of Christian worship." This norm helps to establish the why-ness and the how-ness of true worship because "worship has theological sjgnificance." 2 The revelation of God must govern the character and decide the content of Christian worshịp.

The first and most important norm is fidelity to the Scriptures ${ }^{3}$ because they are the special revelation of God. Fidelity on the part of man is his obedience to that revelation. The theological norm, which has God as its center, is described in the following way:

It (worship) is more than a spontaneous gesture, done by man in his own way. It has to be in harmony with a body of revelation of God which God has given to man. 4

Realizing then, that Christian worship is the essential issue in the life of the Christian believer and that worship education is "long overdue," an attempt is made in the following chapters to come to grips with the concept of "worship" and the theology of Christian worship.

James F. White, "Characteristics of Effective Christian Worship," Studia Liturgica 8 (n.d.): 199.

${ }^{2}$ Norval F. Pease, And Worship Him (Nashville, Tenn.: Southern Assn, 1967), p. 12 .

$$
\begin{aligned}
& 3 \text { von Allmen, p. } 26 . \\
& 4 \text { pease, p. } 12 .
\end{aligned}
$$




\section{CHAPTER II}

A STUDY OF THE WORD "WORSHIP"

\section{The Insufficiency of a Dictionary Approach}

Some authorities define worship by making use of the dictionary. They trace the word back to the primitive Anglo-Saxon word "weorthscipe." From these sources some draw conclusions and apply the dictionary definition in a religious way or reinterpret the word with a theological meaning. Franklin Mi. Segler, who interprets the word "weorthscipe" but does not attach theological depth to the word, gives an illustration:

The English word "worship" is derived from the AngloSaxon "weorthscipe"-- "worth" and "ship"--meaning one worthy of reverence and honor. When we worship, we are declaring God's worth. I

Since worship is a religious concept and has theological significance, the dictionary approach cannot be applied adequately in order to present a theological definition or explanation. Dr. Paul Waitman Hoon, writing extensively and with authority on ecumenical and pastoral studies in liturgical theology, lists four arguments in his comprehensive work why theologians must never interpret worship

$$
{ }^{1} \text { Segler, p. } 5 \text {. }
$$


in the sense of "worthship." 1 Because (1) ". . . the category of i: $i$.

value in biblical thought is secondary to the categories of being, decision, and action;" (2) worship in terms of recognition and ascription of supreme worth to God ". . . does not of itself have anything to do with the particularity of Christian revelation;" (3) to define worship in the sense of ascribing worth to God presupposes that ". . the initiative in worship lies with man . . it is man who 'recognizes' and 'ascribes' worth;" and (4) such an approach "... blurs the discontinuity between the creature and the Creator, between man and God."

In short the purely etymological approach to the meaning of the word "worship" is subjective and anthropocentric. It does not do justice to the revelation of the Scriptures. A proper understanding can be reached only when the objective and theocentric approach is followed.

The Scriptural Meaning of Worship

The Old Testament

The Hebrew word which occurs most often in the Old Testament and is translated with "worship" is shachah. This word occurs usually in the Hith-pael form (i.e., the intensive reflexive mood). \begin{tabular}{c|c}
- \\
\hline $1_{\text {The Integrity }}$
\end{tabular} pp. $91-94$.

The Integrity of Worship (Nashville: Abingdon Press, 1971), 
It means literally "to bow down, to prostrate oneșelf." l Additional words which often accompany shachah, like aretsah (i.e., "to the earth") and gadad (i.e., "to fall on one's knees") leave no doubt as to the meaning of the word shachah. For instance, the Lord and two angels appeared to Abraham by the oaks of Mamre. When Abraham saw them he ran from his tent door to meet them, and ". . . bowed himself to the earth" (Italics mine). 2

In the passing of time this Hebrew word, originally denoting only a bodily movement, ". . had become a cultic terminus technicus." 3 The movement cf the body here is the result of a mental disposition. The person's attitude is demonstrated in showing reverence and by the readiness of rendering service. The individual bows down and/or falls on hij knees.

The Old Testament idea conveyed in this term shachah is reverential attitude of mind or body or both, combined with the notions of "religious adoration, obedience, service.." 4 $\left.\right|_{1} ^{\prime}$ '

The Hellenistic Jews who translated the Hebrew sacred scrolls used the compound Greek verb proskuneo as the equivalent of

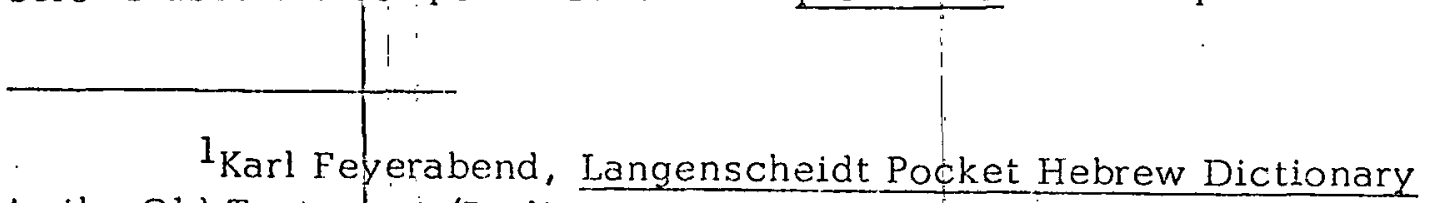
to the Old Testament (Berlin: McGraw-Hill Book Company, 1969), s.v. "shachah." |

${ }^{2}$ Gen $18: 2$; cf. Gen 24:54; the Hebrew reads: wayyishethachu aret'sar.

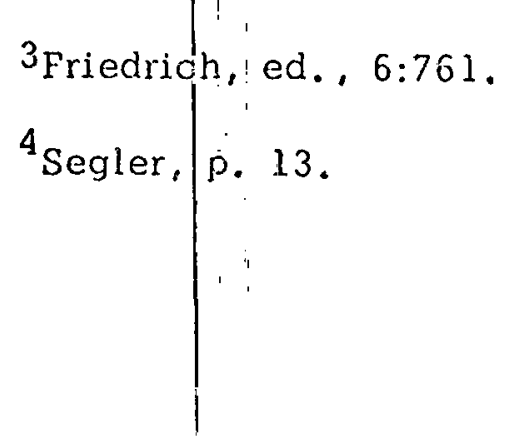


the Hebrew shachah. Proskuneo was ". . used to designate the custom of prostrating oneself before a person and kissing his feet, the hem of his garment, the ground, etc." 1 The Persian people practiced the same custom in the presence of their deified king. The Greeks themselvess used this word to express the adoration of their gods. They practice proskuneō ". . before a divinity or something holy, (fall down and) worship, do obeisance to, prostrate oneself before, do reverence to..." 2

There is, then, no doubt that the element of casting oneself to the ground had a prominence when the Greeks made use of this word. An example is giveni of Odys seus and Agamemnon who prostrate themselves and kiss the earth (proskuneō) after a happy landing. 3 From such facts it is clear that a close similarity between the Hebrew word shachah and its Greek equivalent proskuneō does exist because both words convey the idea of "bowing down" and "prostrating."

Proskunein; the Greek verb, occurs more than two hundred times in the Septuagint, 4 and this verb is the'translation of several

$l_{F}$. Arndt and F. Wilbur Ginrich, A Greek English Lexicon of of the New Testament and Other Early Christian Literature, 1952 ed. (Chicago: University of Chicago Press), s.v. "proskuneō."

2 Ibjd.

${ }^{3}$ Greeven, $6: 759$.

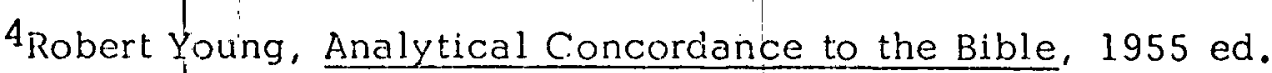
(Grand Rapids: Wm.|B. Eerdmans), s.v. "worship." 
Hebrew words. However, it must be noted that at least 147 times the Septuagint translators made use of the verb, proskunein, as the equivalent of the Hebrew verb shachah. 1

The New Testament

However, when proskunein is used in the New Testament,

which focuses upon the activity of the worshiper, the object is always something divine! Many of those seeking help from Rabbi Jesus of Nazareth practiced proskynesis, not in the sense of a customary form of respectful greeting, but as an expression of true adoration. 2

The wise men from the east fell on their knees and worshiped the little Jesus. They practiced proskynesis "before the Ruler of the world. Satan demanded from Christ proskunein. The disciples of Christ practiced proskynesis as soon as the Holy Spirit could convince them that Jesus was God himself. Reverence and adoration are shown in the act of proskynesis. This is why, the apostle Peter strongly rejected the proskynesis of the centurion Cornelius, saying, "Stand up, I too am a man." Even the angel who was sent to John at Patmos corrected the aging apostle of Christ when he fell down at the $\frac{|i|}{1 \text { Edwin }}$

${ }^{1}$ Edwin Hatch and Henry A. Redpath; A Concordance to the Septuagint and the O'ther Greek Versions of the Old Testament, 1954 ed. (Graz, Austrila: Akademische Druk-U. Verlagsanstallt), s. v. "proskunein."

${ }^{2}$ See Matt 8:2, the leper; Matt 9:12, Jairus; Matt 14:33, the disciples in thelboat; Matt 15:25, the woman of Canaan; Matt $20: 20$, the mother of James and John. 
feet of the angel to worship him. Said the angel, "You must not do that! I am a fellow servant with you. . . . Worship God" (Proskuneson). ${ }^{1}$ It must be observed that even at the end of the first century A. D. the idea of falling on the face or on the knees as an act of worship remained unchanged.

\section{Heinrich Greeven observes:}

Statistics concerning proskunein in the $\mathrm{N}_{\mathrm{I}}$ disclose the astonishing fact that the word is very common in the Gospels and Acts and again in Rev., but that it is completely absent from the Epistles apart from two OT quotations in $\mathrm{Hb} .(1: 6 ; 11: 21)$ and one verse in $\mathrm{Pl}$. (1 Cor 14:25). . . Proskynesis demands visible majesty before which the worshipper bows. The Son of God was visible to all on earth (the Gospels) and the exalted Lord will again be visible to His own when faith gives way to sight (Revelation). ${ }^{2}$

From the foregoing it is evident that both the Hebrew and the Greek words represent some form of self-abasement, i.e., the bowing down, the casting of oneself to the ground, the bending of the knees so that the earth, the feet, or the hem of a garment could be kissed as the expression of reverence to the person who was thus approached. This self-abasement was the individual's humble expression of reverence, honor, high respect to anyone or anything that deserved this. This particular aspect of falling down, prostrating, and the bending of the knees neeci not be specifically interpreted as Christian. It is

\footnotetext{
${ }^{1}$ See Matt 2:2, 11; Luke 4:2-8; Matt 14:33; Acts 10:26;
}

Rev 22:9; cf. 19:10.

${ }^{2}$ See Greeven, 6:765. 
not the only criterion to determine whether such an action is performed in relationship to the "Cod of heaven and earth sinice there are other world religions where the same is practiced. Thus one need not be surprised that in the Old Testament shachah occurs as the descriptive term for the worship of false gods, as well as of the only true God. Proskunein was chosen by the Septuagint translators to maintain that very idea which was conveyed by the Hebrew word. The New Testament writers took over proskunein, thereby expressing that the object of worship is always someone divine, Jesus Christ, the Kurios, God.

\section{Some Non-scriptural Definitions}

Shachah and proskunein, usually translated with "to worship," presuppose a relationship. In terms of Christian worship, there is no worship apart from a close relationship with God through Jesus Christ. There is the inseverable bond between Creator and creature, between Redeemer and redeemed. True worshïp is described as life's greatest experience. In the words of Karl Barth:

(Worship is) . . . the most important and most momentous, majestic thing which can possibly take place on earth; the most urgent, the most glorious action that can take place in human life. ${ }^{1}$

$1_{\text {The Knowledige of God and the Service of God According to }}$ the Teaching of the Reformation (London: Hodder and Stoughton Publishers, 1949), p. 198. 
Thus, on the basis of the study of the words and of the worship activities of the Christian believer in the presence of God, theologians have drawn up various definitions of worship. These definitions"... endeavor to put in a few words the Bible picture of man responding to God's love and grace with thoughtful adoration and reverence." I A selection from among many definitions of worship is presented to demonstrate a particular progress of theological thought.

The Awareness of God

It must be understood that worship always begins with some awareness of God. This awareness can be described as the becoming conscious, the recognition, the perceiving of the presence of God in one degree or another. Rudolf Otto explains how man, in this case Abraham (cf. Gen 18:27), experiences this awareness. He interprets such awareness in terms of "creature consciousness" or "creature feeling." As soon as Abraham realizes that God enters into his earthly existence, he is overwhelmed anew by his own nothingness as compared with that which is supreme above all creatures, namely, the Creator himself. This creature feeling, Otto writes, ". . is the note of self-abasement into nothingness before an overpowering, absolute might of some kind. . .."2

Man is surrounded by many God-revealing evidences: the

lpease, p. 24.

2 The Idea of the Holy (London: Oxford University Press, 1936), p. 10 . 
firmament and nature (Ps 19 and Rom 1:19-20), God's Word (Ps 119; John 5:39). God reveals himself to sinful men in Jesus, His Son (Deut 18:15-19; John 1:1-3; 14:6). Thus the, Creator and Redeemer reveals himself to sinful creatures and they may become aware that $\mathrm{He}$ exists and that He is concerned with them even in their sinful condition. Men may become conscious that they live in relationship with Him, i.e., in His presence. This is reason why worship is defined as ". . . awareness of his presence." 1

\section{The Response to God}

Being aware of the presence of God, such a person responds to such a revelation. Man in his sinful condition usually responds in terms of anxiety and fear, trying to escape from the presence of God. But God reaches out and takes away fear. Thus the human response is usually one of awe. In Gen 28:17 the words of Jacob are significant in this respect. "How awesome is this place! This is none other than the house of God, and this is the gate of heaven." The first response of man confronted with God is one of fear, shudder, awe. Jacob was afraid (verse 17). This was his mental impression and reaction. Rudolf Otto, commenting on this particular verse, writes:

The 'shudder' reappears in a form ennobled beyond measure when the soul, held speechless, trembles

IWilliam Roy McNutt, Worship in the Churches (Philadelphia: Judson Press, 194 1), p. 30. 
inwardly to the furthest fibre of its being. . . But then he comes to his senses, reflects upon this theophany (verses 12-15), and gives the meaningcontent of his feeling. "How awesome is this place" is the typical "primal numinous awe." 1

Worship is described, therefore as ". . . the awed and glad spontaneous response of the spirit of man, confronted by the God of Christian revelation." 2 It is ". . . man's response to God's revelation of himself." 3

The Christian believer, having become aware that God is and that He is continually revealing himself to man (i.e., the Godman relationship), "responds to this heavenly revelation so that a man-God relationship is established.

The Attitude That Marks! the Man-God Relationship

The God-man relationship initiates within the believer an attitudinal change." The believer recognizes his smallness while confronted with the greatness of God; he becomes increasingly aware of his own imperfection in the light of God's perfection. In Christian worship the attitude of the worshiper is changed. Therefore, Christian worship is:

Iotto, pp. 17 and 131 .

${ }^{2}$ Henry Sloane Coffin, The Public Worship of God (Philadelphia: Westminster Press, 1946), p. 15.

${ }^{3}$ Andrew W. Blackwood, The Fine Art of Public Worship (New York: Abingdon-Cokesbury Press, 1939), p. 14. 
- . the attitude of humility, reverence, honor, devotion, and adoration that properly mark the relationship of created beings to their Creator, especially in His presence. ${ }^{1}$

The Experience of the Redeemed

God is worshiped by the Christian believer not only because He is the Creator but also for the fact that this God is his Redeemer. To rephrase this statement in terms of Christian worship: "True worship is God reseen and man remade. "2

It (worship) is an inward experience of those redeemed by Christ Jesus, indwelt by His Holy Spirit, who with Paul can soy that they "worship God in the spirit, and rejoice in Christ Jesus" (Phil. 3:13). 3

Indeed, Christian worship by definition is a redeemed man's response to his Redeemer. ${ }^{4}$ Thus the redeemed person, in his response to God, worships Him because he does not belong to himself; he has become aware that as a redeemed one, he is the blood-bought

${ }^{l}$ Siegfried H. Horn, Seventh-day Adventist Bible Dictionary (Washington, D.C.: Review and Herald Publishing Association, 1960), s.v. "worship."

${ }^{2}$ R. A. Anderson, "Our Worship of God," The Ministry 31 (October 1958): 50. See also his syllabus entitled, "Philosophy and History of Evangeliștic and Pastoral Worship," (Berrien Springs, Mich.: Andrews University, n.d.), p. 13.

${ }^{3}$ Roy G. Irving and Roy B. Zuck, eds., Youth and the Church (Chicago: Moody Press, 1968), p. 192.

${ }^{4}$ See "The Three Angels' Messages and Worship," Sabbath School Lesson Quarterly (Grantham, Linsc., England: The Stanborough Press, 1976), Fourth Quarter 1976, pp. 70, 77. 
possession of Christ. Christian worship may atso be defined as the rulership of God.

The Rulership of God

Christian worship has been defined as "the celebration of the rule of God in the life of the new community in Christ. "2 This rulership of God is possible only because the heart of the Christian believer is wholly devoted to God, who continually reveals Himself as the Creator and Redeemer of mankind through Jesus Christ. Worship then is "the devotion of the heart to God, " 3 so that He is enabled to maintain His love rulership in the worshipful life of the Christian believer. 4

It must be observed, in conclusion, that the etymological approach alone is not sufficient to develop a theology of Christian worship. Whatever the definition may be, the Scriptures need to be approached and studied in order to acquire a deeper insight into Christian worship and to understand its theological implications. Only then will the siudent increasingly appreciate that such worship

${ }_{1} 1$ Cor $3: 32 ; 2$ Cor $10: 7 ;$ Gal $3: 29 ; 5: 24 ;$ Phil $1: 27$.

${ }^{2}$ Millard C. Lind, Biblical Foundations for Christian Worship (Scottdale, Perin.: Herald Press, 1973), p. 5.

${ }^{3}$ J. A. Buckwalter, "Worship is the Devotion of the Heart to God!" The Ministry 30 (July 1957): 26-27.

${ }^{4}$ Matt 12:28; Luke 14:17; 1 Cor 4:20; Gal 2:20. 
is indeed the most momentous, the most urgent, the most glorious action that can take place in human life.

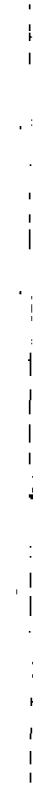




\section{CHAPTER III}

\section{TOWARD A THEOLOGY OF CHRISTIAN WORSHIP}

\section{Introduction}

Christian worshipers share a body of beliefs about God. He is the omnipotent Creator and the Saviour of the world. He is the omniscient Being who knows every thought and action. God is the Father who cares for mankind and who regards the faithful as His children. The faithful realize that they were created and saved by Him in order to return their love to Him and live in harmony with His revealed will. The thesis "As men believe, so they worship"l proves to be correct in the Christian setting also. In other words, what Christians do in worship must grow out of what they believe and teach. 2

Inasmuch as the focus of worship is God, the question whether the person's worship is true worship remains unanswered as long as the theological norm is not applied because worship and theology go together. In his treatise on church and worship, Karl

\section{${ }^{1}$ Segler, p. 57.}

${ }^{2}$ See $C$. Raymond Holmes, "The Liturgical Mission of the Seventh-day Adventist Church.". Paper presented at Andrews University Theological Seminary, February 8, 1973. 
Barth affirms that theology belongs to worship. ${ }^{1}$ The people of Israel in the Old Testament days are a good example of this theological observation. Their worship was theologically grounded. The revelations Israel received from God were, among others, God, the Creator and the Redeemer, covenant God of Israel. As such, Israel was chosen by Him to enjoy His rulership. God is merciful and gracious, steadfast in love, and man is sinful and in need of forgiveness and reconciliation. Israel's worship, then, sprang from the revelation of God and was originally true worship. In the course of history, however, theological uncertainty affected their worship with negative results.

Old Testament worship was theologically oriented; and when men became uncertain about their theology, their worship lost its meaning. .. When prophets of God revived theological truth, worship came alive again. ${ }^{2}$

One function of theology is to ask questions, while the Scriptures provide the inspired answers. Hence, without the Scriptures the church will receive no answer. The theology of Christian worship, then, has as its aim and function not to initiate or create, but to examine, test, and direct the worship of the church so that its worship is in harmony with the Scriptures. ${ }^{3}$ In other words,

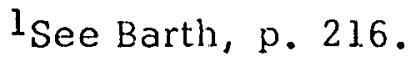

2pease, p. 16.

3 von Allmen, p. 13.
} 
theology based on the revealed Word functions as a corrective to Christian worship. With this principle in mind an attempt is made to develop a theology of Christian worship.

\section{Worship is God-initiated and God-centered}

$$
\text { God-initiated }
$$

The Scriptures reveal that God is the Creator of heaven and earth and the Redeemer of mankind; they end with the vision of a new heaven and the earth made new. Creation and redemption form the fundamental reason for Christian worship. God visited Adam, after he had sinned, to restore the broken God-man relationship (Gen 3:8-9; cf. Isa 59:2, 16-20). He also called Abram out of Ur (Gen 12:1-4), delivered Israel from Egypt (Exod 3:7-8; 7-14), sent His prophets to Israel and Judah and gave His only Son because He loved the world so much (cf. John 3:15). God is the forgiver and the justifier (Rom $1: 16-17 ; 3: 2.3-26 ; 2$ Cor $5: 17-21) ;$ He is the re-creator (Rev 21 and 22). Everything finds its origin in God, Therefore, He is also the initiator of true worship.

It is God who wills that worship is done; it is He who calls and awakens the desire within man to respond (Exod 3:12; 20:2-5; Ps 96:1-9; John 4:23; Rev 14:7). Indeed, "The first impetus of man's religious life and of his worship comes from God." I In order to

$1_{\text {Richard Paquier, Dynamics in Worship (Philadelphia: }}$

Fortress Press, 1967), p. 4, quoting from Le Culte. 
worship God "in spirit and truth" (cf. John 4:24) the worshiper must be aware of the fact that the original and fundamental direction in Christian worship is from God to man; not vice versa.

The Isa $6: 1-9$ passage reveals first of all that the initiative in worship lies with God himself. This initiative is recognized in God's awesome presence, which calls forth from Isaiah both praise and confession, and from God His forgiveness of Isaiah's sin and His call to service, His commission, and His guiding presence in the prophet's ministry. The divine-human dialogue is clearly seen in this passage and discussed later in this chapter; but the criterion emphasized here is that God is first. In worship ". . the initiative is with God." I Hoon makes this theological contribution:

Before the worshipper can express anything, he must first have been impressed with what God has done, is doing, and shall do. That is to say, the theological substance of the Gospel is prior to his doxological response to it. ${ }^{2}$

This trith must be emphasized in Christian worship so that the integrity of worship may be improved and maintained. To the Puritans of the seventeenth century God was ". . . the source of

IOswald B. Milligan, The Ministry and Worship (London: Oxford University Press, 1941), p. 12.

$2_{\text {Hoon, p. } 56 .}$ 
worship--' the fountain from whence floweth all true worship and service of God'." J.

\section{God-centered}

God's creatorship is repeated in the decalogue, affirmed in the poetical hymnody of the Scriptures, reemphasized in the writings of the New Testament, and is proclaimed anew "with a loud voice" in the last days of earth's history by God's faithful worshipers. ${ }^{2}$ Thus the basic reason for the worship of God by His people on earth is in perfect harmony with the archetypical motive for worship of the heavenly creatures who sing, "Worthy art thou, our Jord and God, to receive glory and honour and power, for thou didst create all things . (Rev 4:11).

.. . we do not worship an equal; we worship our Creator, the eternal, infinite God. God is the beyondness of man's existence, the absolute source of being. ${ }^{3}$

Thus God reveals himself as the sovereign Creator and Ruler of all things and of all creatures. In order to become a worshiper of God one must become aware of this truth, become conscious

\footnotetext{
${ }^{1}$ Gordon Bietz, "Word and Worship in the 17 th Century
} Puritan New England with Emphasis on the Massachusetts Bay Colony." Paper presented at Andrews University Theological Seminary, 1974.

${ }^{2}$ Exod 20:8-11; Ps 19:1; 95:6; 100:3; Rev 14:6-7. ${ }^{3}$ Segler, p. 59. 
of His existence, and recognize His ruling presence in the world around. "The earth is the Lord's and the fulness thereof, the world and those who dwell therein" (Ps 24:1). The Scriptures also show the perversity of worship as soon as men do not recognize God as the Creator (cf. Rom 1:21-2.5). Worship, then, begins with the recog-nition that God is the Creator of the universe. From this follows that until men see and recognize Him, they cannot truly worship. ${ }^{1}$

God revealing himself to man as the Creator arouses awe in the recipient of that revelation. In addition to what Rudolf Otto has stated about this awe, it can be observed in this context, that "awe is the awareness by thought and feeling ... that God is God and we are his creatures." This awareness is ". . the seeing at once of God's holiness in power and goodness and our creatureliness in weakness and wrongness." 2

To worship, then, is to worship God, the Creator of heaven and earth. From this it is obvious that Christian worship must have God as its center. God confronts man as the sovereign Ruler. He reveals himself to man as the only One who is to be worshiped (cf. Exod 20:1-6; Rev 14:6-7). Thus, "God is at the center of worship

${ }^{1}$ See H. Grady Davis, Why We Worship (Philadelphia: Fortress Press, 1961), p. 36. See Chapter I1, "Some Definitions.".

${ }^{2}$ H. Grady Hardin, Joseph D. Quillian, and James F. White, The Celebration of the Gospel: A Study in Christian Worship (Nash-ville: Abingdon Press, 1964), p. 23. 
when we are faithful to the scriptural proclamation of who God is." I

Worship: a God-man Interaction

The creation account reveals the truth that as soon as God speaks the word (Hebrew: wayomer; i.e., to say, to speak, to command), there is action. "Thus the heavens and the earth were finished, and all the host of them" For.". . he spoke, and it came to be, he commanded, and it stood forth." 2 It was also "by the word of the Lord" that the heavens were made and the plan of salvation was made effective (Gen 1; Ps 33:6, 9; John 1:14). Christians worship because of an action of God, so that Christian worship may be described as the believer's participation in that action of God. ${ }^{3}$

This participation of the believer could well be interpreted as the God-initiated human reaction. To illustrate: Adam's answer to God when He called him, saying, "Where are you?" (Gen 3:9-21); Abram's response to God by leaving Ur (Gen 1.2:4); or, the Christian's leaving his house to go to church, being aware that God is there to be worshiped. All these are human reactions to God's initiative act of calling. Thus, in Christian worship, God acts and the believer reacts.

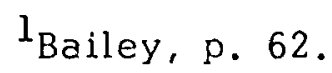

${ }^{2}$ See Gen 2:1; Ps 33:9; Hebrew: wayomer and dabar.

${ }^{3}$ See Hardin, Quillian, and White, p. 27. 
It is the realization of His presence which alone is able to produce the equivalent reaction in us, and to move us to adoration or confession, to supplication, thanksgiving, or intercession, according to the several needs of the soul. 1

This God-initiated reaction is the worshiper's response which, in turn, converts the action that worship is supposed to be into interaction. Christian worship is grounded in the reality of God's action toward His people in Jesus Christ and in the responsive action of the believers through Jesus Christ. ${ }^{2}$ This is what is called Godinitiated, divine-human interaction.

Worship is not just something said, it is something done. In fact, there is in worship a double action, an interaction. God acts towards believers, and believers act toward God. God is worshiped, and the church is built up and strengthened in union with Jesus Christ the Lord. ${ }^{3}$

The prophet Isaiah is an example of the believer's activities (i.e., reactions) in worship. What is being stated in this context is, of course, in addition to what has been said about the Isaiah passage in terms of God's initiative. But Isaiah's reactions are due to God's initiative actions. God reveals himself and the prophet

${ }^{l}$ Milligàn, p. 12 .

${ }^{2}$ Karl Barth writes, "The church service is in the first instance primarily, in origin and in substance, divine action, and is only then human action secondarily, by derivation, and as an accident of the former" (p. 193).

${ }^{3}$ Davis, p. 28. 
stands in awe and confesses his unworthiness. God forgives and the prophet accepts God's mercy. God calls to service and Isaiah dedicates himself to Him. God commissions the prophet to preach judgment and salvation and he serves God by doing just that. This is divine-human interaction par excellence, true worship demonstrated, so that the worship of God by His people may become as interactive as that of the prophet Isaiah.

As soon as the believer pays attention to the self-revealing God in worship, worshipful reactions result like adoration, confession, hearing, dedication, and service. The divine-human interaction is a two-way speech, a communication, a dialogue. Indeed, worship is a dialogue, ${ }^{l}$ but it must always be kept in mind that "the initial call comes from God, who begins the conversation." 2

\section{Conclusion}

From these theological observations worship can be described as "God speaking to his creatures and his creatures making a decent reply to him. "3 Within present-day theological thinking in the Seventh-day Adventist Church this contributive thought is found:

\footnotetext{
$1_{\text {Hoon, pp. 39-40. }}$

2Paquier, p. 8 .

${ }^{3}$ Davis, p. 34. See also Segler, p. 58, where he defines
} worship as "the experience of conscious communion with God." 
. . what takes place at the main worship service on a given Sabbath is not a matter of indifference, because for us, worship is being in touch with . . . the most holy place, and the conmunications. that we receive from God are right from the thione room, from the heavenly court. 1

God speaks to His people through the Scriptures, through the ministry of His Word, through the tokens of bread and wine, through the quietness of the moment. The Christian worshiper reacts by making that "decent reply" to God in listening, partaking, praying, and singing. Christian worship, then, is the divinely initiated means of the God-believer dialogue wherein God reveals His will to such worshiper who, in reacting, makes that reply to Him and leaves His presence in service for Him.

\section{Worship: Its Christology and Christocentricity}

Christendom worships God in the name of Jesus Christ. This is one of the characteristics of Christian worship.

In the previous part of this chapter the attention was focused on the fact that when God speaks, there is action. The Scriptures also reveal that God "is defined by active verbs more than by substantive nouns." 2 From Gen 3:9 onward God is shown to be at work in the realization of the plan of salvation.

Another issue which needs to be addressed in the context of

$$
\begin{aligned}
& { }^{2} \text { Holmes, p. } 7 . \\
& { }^{2} \text { Hoon, p. } 128 .
\end{aligned}
$$


worship is: "How did God reveal Himself to man and how does $\mathrm{He}$ work out the plan of salvation?" He does this most completely in Christ, the Son of God John $1: 14 ; 14: 9 ; 17: 21)$.

\section{Worship and Christology}

The meaning of the frequently occurring tetragram yhwh (literally, Lord), i.e., the covenant God, is applied by the incarnate Son of God to himself. ${ }^{l}$ This implies that God was active in the realization of the plan of salvation in the pre-incarnate Son of God in Old Testament times, who became the Christ of the New Testament times. God revealed himself in yhwh, in Christ, to men. Reconciliation was in operation in and through Christ. Special notice must be given to the phrase "God was in Christ reconciling the world" (2 Cor 5:19); i. e., God was active in and through Christ, redeeming men and women right from the beginning when sin entered into this world. In the Old Testament times "God was in Christ, " while in the New Testament era God is "in Christ." Hence, in Christ, God was and is in action. God was anci is speaking in and through His Son, the Incarnate. ${ }^{2}$ It is observed that "the heart of the action is God's deed in the person of His Son Jesus, the Christ." 3

${ }^{1}$ Cf. Ps 23:1, yhwh is my shepherd, and John 10:11, "I am the good shepherd." Cf. ego eimi of this text with LXX, Exod 3:14. ${ }^{2}$ John $1: 1-3,10 ; 5: 30 ; 14: 31 ; 17: 21$. ${ }^{3}$ Tietjen, p. 1.46 . 
All that Christ did in His pre-incarnate existence and while He was in the flesh on this earth was due because God was at work in Him, and He will continue to work in and through Him to save His people from sin. Dr. Paul Waitman Hoon expresses the Christology in a profound statement:

The action of God's word supremely comes to focus in the Event of Jesus Christ. While this Event includes God's total action in history leading up to it and flowing from it, in another sense this Event stands by itself and uniquely embodies God's action. ${ }^{1}$ (Italics mine)

From this Christology the conclusion may be drawn that Christian worship is in nature incarnational. Because it is in Christ that God calls His people unto himself John 6:44; Heb 10:19-22; Jas $4: 8$ ). In Christ, God extends forgiveness and reconciliation (2 Cor $5: 18-20 ; 1$ John $1: 9$ ). In the reading and hearing of the Scriptures, Christ is revealed, who reveals His Father (John 1:1-3, $14 ; 5: 39 ; 14: 6)$. in the tokens of bread and wine, God is at work in Christ in Christian worship (Matt 26:26-29; 1 Cor 11:23-26). This fundamental truth is an indispensable theological criterion which must be applied to determine whether Christian worship is true worship, i.e., acceptable to God.

The observation was made that all worship has the characteristic of a response. Therefore, Christian worship. "is primarily the response that man makes in gratitude for what God has revealed

$$
l_{p, 128}
$$


to us and done for us in Jesus Christ His Son." I

$$
[\ldots, \cdots, \quad \text { an } \cdots
$$

Worship and Christocentricity

Christ made the covenant promise, ". . I am with you always, to the close of the age" (Matt 28:20). These words have to be understood in their context. The disciples worshiped Him (verse 17) and Jesus Christ did not reject their worship. And while they were worshiping Him, He came near and made the promise of His continual presence with them.

In Matt 18:20 Christ announces His presence in the midst of only two or three gathered in His name. When Christians come together "in His name," Christ is in their midst. This promise is at the same time the divine affirmation that because He is present and in their midst, He is also the center of such worship. Man in his response to God can meet the Creator and Redeemer only by and in the encounter with the person Jesus Christ (John 14:6). Therefore, "worship of God is made possible in the person of His Son." 2 Both through His divinity and humanity "Jesus Christ is the unique and proper place for the encounter between God and men. He is their living bond and link, and is therefore the center of worship" 3 so that

$$
\begin{aligned}
& 1_{\text {Milligan, p. } 14 .} \\
& { }^{2} \text { Segler, p. } 61 . \\
& \text { 3Paquier,"'p. } 19 .
\end{aligned}
$$


"the very life of Christ is met and can be received in worship." I

To conclude, it is a statement of faith to say that the living Christ is present for every man and woman who has come to worship "in spirit and truth." Judeo-Christian believers realized and acknowledged this presence and lordship of the resurrected Christ and that $\mathrm{He}$ was in their midst when they worshiped. Therefore, God-initiated, Christological and Christocentric worship "as man's faith-event finds reality in the Christ event--incarnation, cross, and resurrection." 2

\section{Worship and Pneumatology}

What has been stated about the theology and the Christology of worship is intimately linked with the pneumatology of worship. Father, Son, and Holy Spirit are inseparably linked together and interrelated. The three persons of the godhead are God triune.

\section{The Relationship between the} Holy Spirit and Worship

It is understood from the Old Testament that the Holy Spirit was active in creation (Gen $1: 2,26$ ), and the New Testament reveals that no person can experience recreation unless by the Holy Spirit (John 3:3-8). In Old Testament times the Holy Spirit inspired the prophets of God (e.g., 2 Sam 23:2; Ezek 2:2), who proclaimed the

$$
\begin{aligned}
& 1_{\text {Hoon, p. } 145 .} \\
& { }^{2} \text { Segler, p. } 68 .
\end{aligned}
$$


coming of the Miessiah, while in the New Testament era the Holy Spirit bears witness to the salvific fact of what God has done and what He is doing in Christ (John 14-16).

The Holy Spirit convinces the world of sin, righteousness, and judgment (John 16:8). It is only by the Holy Spirit that rebirth takes place (John $3: 3,5 ; 6: 63$ ), and it is by the Holy Spirit that Christ is continually present in the faithful church (John 16:7, 13-15; 20:22). All God's children are "in the Spirit," the criterion being that the Spirit of God dwells in them (cf. Rom 8:9). It is, therefore, by the Holy Spirit that the Christian believer worships and that God acts and gives guidance in worship through Him (cf. Rom 8:26-27;

1 Cor 14:24-25; Eph 5:18-20).

The Holy Spirit and Worship

The Christian worshipers are then dependent on the Holy Spirit for worship. The worshipers sing, pray, listen to the Word, confess and dedicate themselves, and leave the worship as servants of God. This they can do only by the Holy Spirit.

It is the Holy Spirit's function to inspire and guide the church in its worship and work. . . (He) gives the church motivation for its ministry. 1

Karl Barth affirms that the worship of the church "is not the work of man but the work of the Holy Spirit and consequently the

$$
{ }^{1} \text { Segler, pp. } 64-65 \text {. }
$$


work of faith." 1 From these observations it follows that unless the Holy Spirit enables the believer, he cannot truly worship God. ${ }^{2}$ This, of course, is an aspect which is interrelated with soteriology, for only the person who has experienced rebirth and lives the life of salvation is in the position to truly worship God in the name of Jesus Christ, his Lord.

In the discussion of the Christocentricity of worship it was stated that in worship Christ is present in the midst of His people. The question, "How is Christ's presence in the church a reality while He is bodily in the heavenly sanctuary?" needs an answer. The presence of the Lord Jesus Christ is manifest in His church by the Holy Spirit (Matt 28:20; John 17:23; I Cor 3:16).

Indeed, it is only when the risen Lord breathes upon the assembled believers and says, "Receive the Holy Spirit" (John 20:20) that he is recognized as being present and the worship dialogue becomes a real encounter. ${ }^{3}$

This means implicitly that if God's people neglect or even ignore the Holy Spirit, their worship becomes what it really should be: their worship. However, when God's people assemble for worship "in the Spirit," then God is meeting with His people. 4

${ }^{1}$ Barth, p. 198.

2 See Hardin, Quillian, and White, p. 14.

${ }^{3}$ Paquier, p. 24.

${ }^{4}$ See Ellen G. White, Prophets and Kings (Mountain View, Calif.: Pacific Press Pub. Assn., 1917), p. 50. 
Franklin M. Segjer pointedly remarks, "The Spirit of God or the Holy Spirit is always God-at-hand . . . is always God-at-work." I

Since the Holy Spirit is manifestly at work in and among the worshipers, it is also this person of the Godhead who brings them into communion with God when they worship. Then dialogue has begun. When God's faithful people have been brought into the pres ence of God in Christ's name by the Holy Spirit; it is also the work of the Holy Spirit to further inspire and guide the worship act and the mission of the church by using the gifts which He has bestowed upon them. Worship, therefore, is the means through which additional grace is received to grow in faith so that the worshiper is changed into the likeness of Christ, the Lord, "from one degree of glory to another" (2 Cor 3:18).

\section{Worship "in Spirit and Truth"}

The phrase "in spirit and truth" is unique in the New Testament. It occurs in John 4:23. In its context the issue under discussion is "Where must people worship, in Samaria or in Jerusalem?" Worship is in this question geographically limited to Samaria or to Jerusalem. However, this is really not the issue for Christ. Worship is lifted up by Him to its original and rightful place,

$$
{ }^{1} \text { Segier, p. } 63 \text {. }
$$


namely, "in spirit and truth." Christ's unique expression is the criterion for worship to be true and genuine. Only genuine worshipers can truly worship God. Heinrich Greeven comments:

In the context of the conversation with the Samaritan woman it means "genuine worshippers." The words "to worship in spirit and in truth" offer a definition of "genuine." 1

Christ's truth-revealing statement also lifts the act of worship to a new dimension, a new reality, which had always been the reality in God's view. Thus the traditional worship in the temple of Jerusalem, or, for that matter, in any place in the world, is replaced by the "altogether different worship" 2 which is true worship. There is no longer to be any exclusive place of worship in order to make worship true worship. Christ answered the question of the Samaritan woman by explaining the nature of true worship. That is the spiritual nature, i.e., inspired by the Holy Spirit who guides God's people "into all the truth" (John 16:13). "In spirit and truth" means, therefore, that genuine worship must spring from the heart, inspired and guided by the Holy Spirit. Christian worship must be "in truth," i.e., in harmony with the divine revelation. Stated differently, the faithful believer worships God "in spirit" when he approaches by the

\section{$1_{\text {Greeven, 6:766. }}$}

${ }^{2}$ Ellen G. White, The Desire of Ages (Mountain View, Calif.: Pacific Press Pub. Assn., 1940), p. 13. 
Holy Spirit the "throne of grace" (Heb 4:16; 6:19) in Jesus Christ, presenting himself wholly and undividedly. He worships God "in truth" when his worship "is harmonized with the truth of the life that is in Christ, "l who is the "way" of worship.

These statements about "in spirit and truth" are confirmed

by the following words:

Not by seeking a holy mountain or a sacred temple are men brought into communion with heaven. Religion is not to be confined to external forms and ceremonies. The religion that comes from God is the only religion that will lead to God. In order to serve Him aright, we we must be born of the divine Spirit. This will purify the heart and renew the mind, giving us a willing obedience to all His requirements. This is true worship. It is the fruit of the working of the Holy Spirit. ${ }^{2}$

A method to synthesize the theology, the Christology, and the pneumatology of worship is to present a trinitarian statement on worship. Creation and redemption teach that "God has acted in His Son and in His Spirit."3 Worship, therefore, is the genuine worshiper's response to the Father in Jesus Christ, in harmony with special revelation, prompted and guided by the Holy Spirit.

Christian worship is the doing of God, for the heavenly

$\mathrm{l}_{\text {Paquier, p. } 24 .}$

${ }^{2}$ Ellen G. White, Desire of Ages, pp. 160-61 (italics mine). See also Prophets and Kings, p. 50.

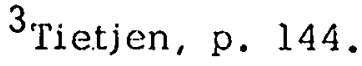


Father offers to His children His saving love through His Son, while the Holy Spirit opens the hearts of these faithful to the Father's love and enables them to respond to Him in joyful acceptance and obedience, which is worship. ${ }^{1}$ Thus God is known in worship as Father, Son, and Holy Spirit.

God the Father stresses the ultimacy and certainty of his existence as expressed in his creation. Jesus Christ defines the character of God expressed in his redemptive love. The Holy Spirit affirms the intimacy of his life expressed in his never-failing availability. ${ }^{2}$

These are some of the theological reasons why Christian believers can only think in faith and obedience about Christian worship in the name of the Father and of the Son and of the Holy Spirit. To educate God's people in the trinitarian approach and practice of worship may result in a deeper consciousness of the truth that it is only (1) by the Holy Spirit that as worshipers they can say, (2) "Jesus is Lord" to the (3) glory of the everlasting Father.

\section{Worship and Soteriology}

Worship: the Resultant of Salvation

There is a theological impact of the faith of the patriarchs and of the people of Israel on the worship of the church. Both the patriarchs and the people of Israel experienced deliverance. No

${ }^{1}$ See Hardin, Quillian, and White, p. 14.

${ }^{2}$ Segler, p. 65 . 
person could truly worship cod without experiencing deliverance. From each group an example is taken to substantiate the statement that worship is soteriological.

A. The experience of Abram. After leaving Ur and wandering through the lands, Abram built altars to worship God (cf. Gen 12:7-8; 13:4, 18; etc.). The last recorded altar which Abraham built (Gen 22:9) was a demonstration of the greatest sacrifice he had determined to make in his worship of God. Abraham's life shows that God took the initidive by calling him out of Ur and leading him from altar to altar till he had grown so much in his faith-worship experience that he was willing to even sacrifice his only son (Heb 11:17) to the Lord. Abraham knew that God would "provide the lamb for a burnt offering" (Gen 22:8). It was by faith that this patriarch reached such height of worshipful life (Heb 11:17-19). From this example the conclusion must be drawn that worship is: (1) the response of the believer to God's calling, saving, and sustaining actions; and (2) a dynamic or progressive reaction on the part of man.

B. The people of Israel. God took the initiative in saving Israel from the Egyptian bondage so that they could worship and serve Him in freedom (Exod $3: 18 ; 4: 23 ; 5: 1,3$; etc.). "So he led forth his people with joy, his chosen ones with singing. And he gave them the lands of the nations. . . to the end that they should keep his statutes, and observe his laws" (Ps 105:43-45). By God's 
saving intervention Israel was set free so that in freedom they could truly worship their Saviour-God. Hence, the reason why the Israelites worshiped God was "essentially a remembrance or memorial of God's saving actión." l

This is another reason why worship is due to God, namely, He saves so that people can worship Him. The question is asked, "How does salvation tie in with worship?"

God Reveals Himself--Man

Is Revealed Sinful !

God reveals himself as Creator and Redeemer and this revelation is altogether His gracious initiative. Due to his sinful nature, man always attempts to flee away from God. He wants to hide himself from God because he realizes that he is unworthy to meet his Creator-God. In fact, when God mets man, two revelations occur. They are the revelation of God initially and, as the result, the revelation of the condition of man. ${ }^{2}$

The experience of the prophet Isaiah is again, a perfect illustration of this double revelation: (1) God reyeals Himself (Isa 6:1-4), and (2) man's condition is revealed and recognized, "Woe is me! For I am lost; for I am a man of uncléan lips, ..." (verse 5). New

From the New Testament the following illustration may $\frac{}{1 \text { IS. S. Garret, Christian Worship (London }}$ Press, 1963), p. lit.

${ }^{2}$ See Barclay, 2:149. 
suffice to substantiate this double revelation: Christ reveals himself to Saul (Acts 9:1-6); Saul realizes his spiritual condition, though he previously thought and taught that he was perfect in his service and worship of God (cf. Phil 3:4-6).

As soon âs God reveals himself to man

-. the consciousness of moral failure becomes something different: it becomes a sense of sin against God, a sense of having disobeyed the will of God, of having betrayed the love of God. . . "Thou hast set our iniquities before thee, our secret sins in the light of thy countenance." That makes the situation, worse than ever. 1

Sin is a state in which man is separated from God, the source of life, and as such, man has separated himself from his neighbor and from/himself (cf. Isa 59:2; Rom $15: 12 ; 6: 23 ; 8: 10 ;$ Eph $2: 1$ ). On the other hand! sin is even . . man's effort to deny his creatureliness, to claim for himself the role of God. This stance separates him from life and expresses itself through concrete acts which destroy and fracture those about him as well as destroying himself. . His sin is his attempt to pretend that he is all-wise, all-powerful, and all-good! 2

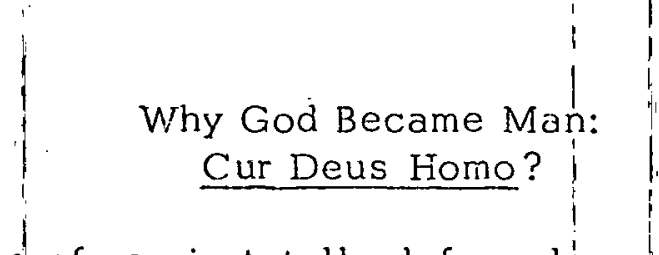

Man, therefore, is totally defenseléss against God. ". . . his situation before the Word is rightfully felt to be fateful." 3

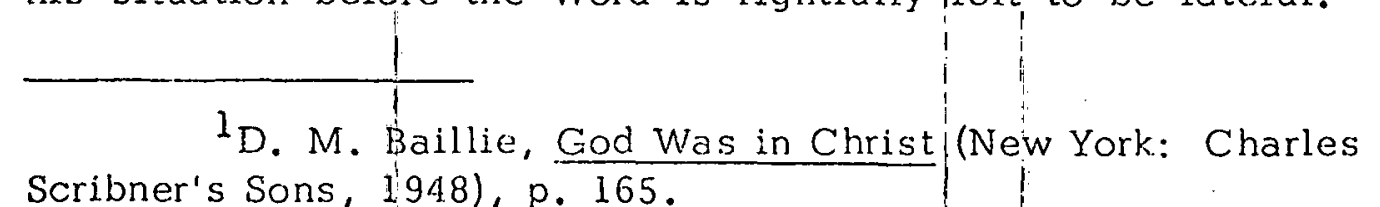

Scribner's Sons, 1948), p. 165.

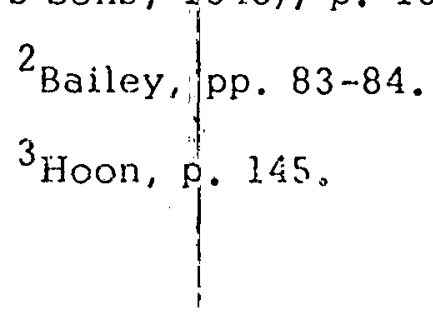


God did not reveal himself, however, as the just judge only, but also as the merciful and righteous justifier. The observation is made that "were there no justice, no penalty, there would be no stability to the government of God. It is the mingling of judgment and mercy that makes salvation complete." 1

To the theological question, "Cur Deus. Homo?" is the Christological answer that Christ came into the world to save sinners (1 Tim 1:15; cf. Mark 10:45; 1 John 4:10). This gospel was reworded by John Calvin as follows: "Christ actually did 'come to redeem us from sin, and that, is enough." 2 For this reason the Son of God became the Son of man. Stated differently, Jesus Christ, the W'ord of God, became flesh "to deliver men from evil, to break the bondage of sin that enslavés the will, and to do on the cross that deed which can save from guilt, corruption, and death." 3

${ }^{1}$ Francis D. Nichol, ed., Seventh-day Adventist Bible Commentary, 7 vols. (Washington, D.C.: Review and Herald Publishing Association, 1953-1957), 5:1133 (hereafter abbreviated SDABC).

${ }^{2} \mathrm{My}$ translation from: Johannes Calvijn, Institutie (Kampen: J. H. Kok, N.V., 1958), p. 86. Cf. John Calvin, Institutes of the Christian Religion! 2 vols. (Grand Rapids: Wm. B. Eerdmans Publishing Company, 1957), 1:405,"'. . a faithful saying, and worthy of all acceptation, that Christ Jesus came into the world to save sinners' (1 Tim 1:l5), in it I willingly acquiésce." See also Gustaf Aulen, Christus Victor (New York: Macmillan Company, 1969),
p. 106 .

$$
{ }^{3} \text { Hoon, p. } 140 .
$$




\section{Confession--Forgiveness}

Salvation, the deliverance from the dominion of $\sin$, is available to all men. However, salvation is the experience only of those who believe; and accept this salvation.

Isaiah confessed his unworthiness due to his own sins (Isa 6:5), because, in the presence of God's holiness he became fully aware of his own moral condition. Saul was converted on the road to Damascus because Christ revealed himself to him and Saul realized that his own perfection (Phil 3:7) in the light of that of Christ's was just vanity (verse 8 ).

The individual who by grace is exposed to the revelation of God and His holiness experiences his utter unvrorthiness, so that he, too, will excláim, "Woe is me!" and "Wretched man that I am!" (Isa 6:5; Rom 7:24). This confession is initiated and prompted by the Holy Spirit (John 16:8; 2 Cor 7:10). Therefore, the situation of the sinner in confrontation with God's holines's is not only worse than ever, but it is "also better than ever, with a quite new possibility, because of the divine forgiveness. "1 To worship, then, means to be human, full of faults and sins, but also full of possibilities granted by grace.

Our confession is really Good News. Only when we

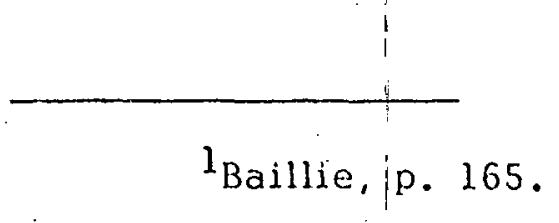


start from our true condition is there hope of our being made new. God's judgment on us is always at the same time his love. He judges to redeem us. 1

It is obvious, of course, that confession is an indispensable and thus an essential element in Christian worship. The Augsburg Confession uphold s this scriptural truth in formulating that "the highest worship in the Gospel is the desire to receive forgiveness of sins, grace, and righteousness." 2 The sequence of experiences in worship soteriology is therefore: revelation, recognition, confession, followed by forgiveness of sins, i.e., justification and salvation.

The forgiveness of sins is explained as follows:

God's imputation or reckoning of Christ's righteousness to the repentant believer's account before God (Rom 4:4-8). It is a judicial transaction of Christ as heavenly mediator, by which we are! set right with God and have access to the Father's heart (Rom 5:1,2), the immediate result being that "God's love has been poured into our hearts through the Holy Spirit, which has been given to us" (Róm 5:5, RSV). ${ }^{3}$

In Christian worship God forgives, the repentant sinner into the new life in Christ through the Holy Spirit. A siricere Christian is never, disappointed when he approaches God in humble confession. God has planned that men be saved by Hiis grace

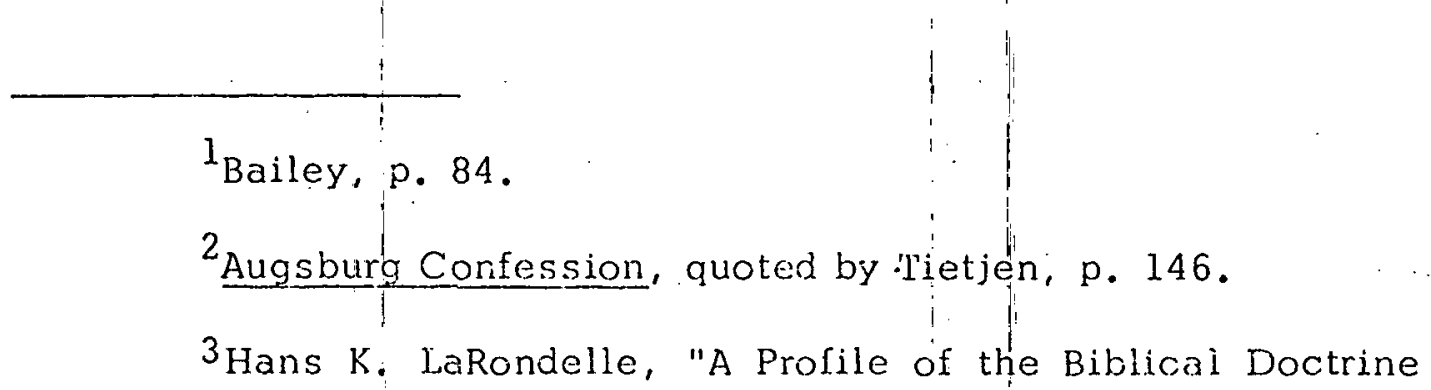

${ }^{3}$ Hans K. LaRondelle, "A Profile of the Biblicai Doctrine of Salvation," Review 154 (January 6, 1977): 6. 
through faith (cf. Eph 2:8). In worship, then, everything comes from God. This grace "draws man out of his darkness, raises him from the dust of a very small and sinful creature, and tears away the veil which hides from him the knowledge of his Creator and Savior." I

From the foregoing it is evident that nobody is able to worship God "in spiritt and truth" unless he has accepted the gift of salvation, Jesus Christ, and experienced confe's sion and the forgiveness of sins.

Salvation in Worship

It is proper to remember that what has been stated thus far about Christian worship is applicable to personal worship as well as to corporate worship. It is understood that when Christians assemble for worship they enter into the holy presence of God, who is the righteous Judge and the merciful Justifier. Being conscious of the perfect holiness of God (cf. John 17:11, 25)! His people realize that they are but sinners and therefore "fall short of the glory of God" (Rom 3:23). Under the prompting of the Holy Spirit they humbly confess their sins, like Isaiah and Paul, in the presence of God. Unless the church" "comes repeatedly to confession it cannot remain the witness of God's saving grace. "2

$$
\begin{array}{l|l}
1_{\text {Paquier, }} & \text { p. } 16 . \\
2_{\text {Segler, }} & \text { p. } 73 .
\end{array}
$$


To emphasize the importance of this essential part of Chris-

tian worship, a personal experience is illustrative of what takes

place when the believer enters into God's presence to worship Him:

The moment I face God, I also recognize myself for what I am. Ónly before God I know what I am, what my responsibilities are, and what is possible for me. The moment before God is the moment of truth. Then I know how I have shirked and evaded my responsibilities, failed to be what I could, been what I should not and did not have to be. 1

Confessions like "Woe is me!" and "Wretched man that I am!" must become the basic outflows of every believer's exposure to the holiness of God, so that His mercy in forgiving becomes the personal and congregational experience in worship. If there is no awareness of the presence of God, of God "being-at-hand, "there will be no consciousness of sin and guilt and, consequently, no confession of sin either. If such is the case, forgiveness is not extended, neither received, let alone experienced.

This essential element of worship is also emphasized.in present-day Christianity in the following words:

.. the promise of cleansing through God's grace must be made so real that the people can receive anew the experience of sins forgiven. This joy of sins forgiven through God's grace is the very center of salvation by faith. 2

The quality of the worship of God can be improved when these

IDavis, p. 37 .

2 Pease, pp. $54-55$. 
indispensable elements of worship like God's presence and His judgment, man's utter sinfulness and his confession of sins, God's gracious and merciful forgiveness could be more explicitly declared in Christian worship. Passages from the Scriptures, suitable hymns, congregational confession, and the declaration of sins forgiven are the instruments to accomplish that. It is stated: ". . humiliation, repentance, pardon, and reconciliation have to be declared and lived anew always in our worship which is set on this earth." I The soteriology of Christian worship, in conclusion, could be restated as follows: Christian worship is the God-initiated instrument through which justification, i.e., the forgiveness of sins, is extended to the confessing Christian(s). Only when there is a Sola Fide acceptance of sins forgiven on the basis of a humble confession Sola Gratia, worship continues to be worship "in spirit and truth." This is the indispensable salvific sequence of worshiping the Creator-redeemer God, according to Sola Scriptura.

\section{Worship and Ecclesiology}

The church does not consist of one but of many individuals who experience justification by faith, the forgiveness of sins. The next issue which needs consideration in the context of worship is what relationship exists between worship and church. Since

$1_{\text {Paquier, p. 24: }}$ See also Bailey, p. 31 . 
the concept of church presupposes mission, questions are raised like: "Which comes first: mission or worship?"

Though the topic "mission" is discussed in the following paragraph, it is necessary to explain here the proper sequence of worship, church, and mission.

From a strictly theological view, it is understood that the origin of mission is in God, the Creator and the initiator of all things. God is the sending God. He sent angels (Gen 16:7; 18:1 -2; Ps 34:7; Dan 9:21-22; Matt 1:20; Rev 1:1); He sent His prophets (Exod 3; Isa 6; Jer 1; Amos 7:15); He sent His apostles (Matt 10:5; 28:19); yes, He sent Christ (John $3: 17 ; 17: 18$ ). This sending action of God was responded to by men. Repentant sinners became children of God; the church was called into existence (Eph 2:8-10, 20-22). From God's point of view, mission was first. However, when mission is looked at from an ecclesiological angle, then the priority in the churchmission sequence is different. This is the reason why in the context of worship the question is raised in a legitimate way: "Which comes first, mission or worship?" Another question in this respect is: "What effect does worship have in the church?" or "What takes place when the church worships?" The attempt is made in the following pages to answer these fundamental questions in the context of what has been stated thus far. 
The Priority of Worship

The thesis is maintained by ecclesiologists that the church exists for the world. From a missiological point of view this sounds acceptable. The basic truth, however, is that the church exists first of all for God. As a people the church meets God in worship from whence He sends them into the world. This worship priority is formulated as follows:

First and foremost the Church exists. for God. He has called this people out of the world to be His special people. . . that they may give to Him the glory which is due to His name. So the first duty of the Church is worship. 1

This theological dimension of the relationship between worship and church is clearly revealed in the New Testament. When Christ had been taken up into heaven the disciples left Mount Olivet and went back to the upper room in Jerusalem and "with one accord devoted themselves to prayer," (Acts 1:4-9, 12-14) waiting for the fulfillment of Christ's promise. The early church gathered first of all to meet with God and to receive the promise of the Holy Spirit. Then they received the heavenly power and authority to go out and preach the gospel (i.e., mission).

The church in history must always be what the early church was after the ascension--a group of redeemed people gathered together to pray and to wait for the coming of the Holy Spirit. . . Only as a worshiping

IJohn R. W. Stott, One People (Downers Grove, Ill.: InterVarsity Press, 1968), p. 73. See Segler, p. 73. 
congregation can it be the church in history. The church is born today, as it was in the begirning, by a miracle of grace in the hearts of believers. 1

The very word "church" (from the Hebrew qahal and the Greek ekklēsia) has strong overtones of worship, for the church is in essence the congregation of people who by faith live in the salvation of Jesus Christ. Since God is Creator and Redeemer, He is also the very life of His church. Worship, then, is the very act by which that life is extended to and is operative in the church. From this follows the conclusion that "the primary function of the church is the worship of God. Only as we worship are we able to effectively work for God." ${ }^{2}$ Thus is worship the very first action in and for the church's life.

Through the gift of worship, the church becomes aware of itself as the people of God, as the body of Christ, and, consequently, presents itself as such before the worid. In other words, in worship a two-fold identification takes place, namely, the church repeatedly realizes that they are God's children and the world must recognize that the people who assemble there and then are a special people. ${ }^{3}$

${ }^{1}$ Segler, p. 73 .

${ }^{2}$ Franklin M. Segler, A Theology of Church and Ministry (Nashville: Broadman Press, 1960), p. 191.

3 See Paquier; p. 18. 
To sum up: worship is the God-initiated act whereby the mystical body of Christ, the church, becomes visible before the world as God's people. As stated elsewhere, worship is the church's "preeminant self-realization" ${ }^{1}$ by God's grace and faith in Christ. Therefore, when one says "church" he is implicitly saying "worship."

Worship Implies Koinönia'

The church is brought into existence by salvation which is offered to this world by the heavenly Father in His only Son. This salvation is administered by the Holy Spirit. The church cannot exist on an individual basis. The Hebrew and Greek words also imply corporateness and that of a special nature. Men and women are saved out of their corporate sinful condition (Rom $3: 23 ; 5: 12$ ) as individuals and are placed in Christ into the new corporate fellowship of brotherly love (John 3:16; 1 , Cor $1: 9 ; 1$ John $1: 3,6-7 ; 3: 2) !$ "Fellowship" or "communion" are interpretations for the Hebrew gahal and the Greek ekklēsia. One understands them to rise from the very nature of the church. The apostle Paul, writing about the unity-in-diversity concept of the church, explains, "We, though many, are one body in Christ" (Rom 12:5). This oneness, fellowship, then, is another aspect of the essence of the worship of the church. For "Christian worship serves God's purpose to bring his children into a community $\frac{1}{1}$.

${ }^{1}$ See Hoon, p. 34, where he quotes, from "The Constitution of the Sacred Liturgy in Retrospect, ". Worship 40 . 
of faith, at one with him and with one another." 1

This community of faith is brought together by God's

love. Though the pryous quotation does not explicitly mention l. $\because \therefore<$ is

the word "fellowship," it does emphasize the fact that the Godman relationship has been established from which the man-to-man relationship springs forth. It is the agapè love relationship that exists in the fellowship of believers (koinonia), so that they are at one with God and with one another (1 John 4:19 and 7-9). This is the outgrowth of God's love for the repentant sinner who responds to God and to his neighbor in love-the church is, therefore, all God's making, His action, His recreation.

Christians are not one church because of anything that is in them as a people. ... The oneness of the church is not of our making. It is a bond we can neither make nor break. 'Christians believe it is God's love, not our love that makes us ore. ${ }^{2}$

Such oneness means fellowship, koinönia, in Christ, the Lord of the church. The issue which needs to be addressed is: "What effect does worship have on this fellowship?"

Worship has a two-fold effect, namely: (1) worshipactualizes the fellowship, and (2) worship produces fellowship.

${ }^{1}$ Hardin, Quillan, and White, p. 15.

2 Davis, p. 24 . 
A. Worship actualizes fellowship. The faithful worshipers gather together. The very being of the worshiper is being merged with the being of the fellow worshiper, through being merged with Christ. ${ }^{l}$ There and then the worshipers actualize and show through grace and by faith the fellowship they have with each other. They worship together because they share a common life, i.e., the life of Christ, and thus they want to share their common life with each other. ${ }^{2}$ Fellowship is actualized and demonstrated when the church gathers for worship "in spirit and truth." 3

B. Worship produces fellowship. Love begets love. Because God first loved the sinners, the repentant ones are enabled to love Him too. In the context of its ecclesiology, this responsive love towards God is expressed in love towards fellow believers, while from a missiological point of view this same love is expressed to one's fellowmen (cf. Matt 22:37-39; l John 4:7-21).

What, then, is the function of Christian worship? Worship is the God-initiated means by which the love can be increased and multiplied, for "worship produces fellowship with God and loving

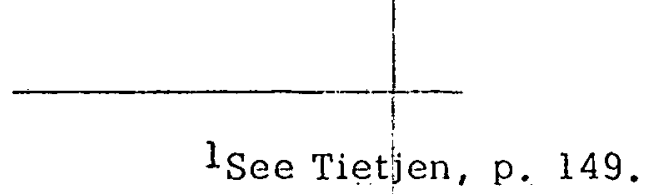

2 The koinönia unity is strongly implied by these New Testament imageries: John 15:5; Eph 5:23; Col 1:18; 1 Pet 2:4-6; John 10:1-18.

${ }^{3}$ See Segler, Christian Worship, p. 171 . 
fellowship with God's children within and without the church." 1 The more worship is done "in spirit and truth" the more mature the fellowship will grow.

According to the ecclesiology of worship the conclusion must be drawn that Christian worship presupposes a love corporateness, both in its actualizing and in its producing character.

\section{Recapitulation}

To repeatian earlier observation, the church does not consist of one, but of many members. Though many are saved by grace through faith (Eph 2:8), each individual believer carries his own responsibility in worship. When the church in its corporateness in Christ worships God, each individual Christian has his personal part in the act of worship. "The church's worship is personal participation by acts of faith. . . " 2

Worship from the ecclesiological viewpoint is then the act of approaching God as the corporate church, as the fellowship of believers, as Christ's royal priesthood (cf. Exod 19:5-6; Rom 12:1-2; 1 Pet 2:0; Rev 1:5-6). Though worship is corporate, this worship by the church is simultaneously an individual act. The church can

${ }^{1}$ L. K. Dickson, "Our Worship of God," The Ministry 31 (October 1958): 49 :

${ }^{2}$ Segler, Christian Worship, p. 74. See also Raymond Pannikar, Worship and Secular Man (Maryknoll, N.Y.: Orbis Books, 1973), p. 90 . 
worship as one people collectively because each individual believer participates in this worshipful act. Through the ministry of the Word, God speaks to His, people, but there is also the God-man dialogue going on at the sarne time. The church as a fellowship and as a royal priesthood (1 Pet $2: 9)$ rededicates itself to God for mission, but each faithful worshiper says to his Creator-Redeemer: "Here am I, send me!"

The dialectic between the individual worshiper and God and between the congregation and God is beautifully illustrated in the following testimony which emphasizes both the individual and the collective response in worship "in spirit and truth." us would have made by himself, a shared response to a shared Word. : Any other person in this group is as important as I am, and the group itself is more important than any of us. . I I am called to do what nobody on earth but I can do: to worship and serve God for myself with my own life. I am called to do something in the church service that nobody else can do, that cannot be done unless I do it. I am called to join my own heart's prayer ard praise and thanksgiving to that which goes up to God from the whole church. Nobody but I can do that, and if I do not do it, it will not be done. But the church's worship is not complete until I join in making it. l

\section{Worship and Mission}

Thinking about church, one simultaneously thinks about the function of the church, which is mission. In both the Old and the 
New Testaments are statements which reveal that God is the sending God. "Our God is a missionary God," it is observed. It is therefore necessary to have a closer look at the relationship between worship and mission.

The Relationship: Worship--Mission

God is the source of life (cf. John 1:1-4) and He is the life of the church (Col $2: 9-10)$. Worship is also the act through which life is made available to God's church through Word and sacrament. The church consists of people who experience salvation in Christ, and the church exilsts for the purpose of worshiping Him through service, i.e., mission. Franklin M. Segler writes: "God's purpose for the church is redemptive. . As a redeemed fellowship, it is also a redeeming fellowship." 2 (Italics mine)

As observed earlier, the primary task of the church is to worship God. It is through its worship that the church is enabled by God to effectively work for Him in mission. This seeming dichotomy is solved when it is understood that the esse of Christian worship must embody apostolicity. 3 Worship is not to be equated, however,

${ }^{1}$ Gottfried Oosterwal, Mission. Possible (Nashville: Southern Publishing Association, 1972), p. 70.

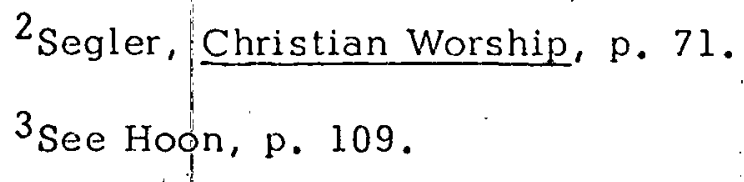


with apostolicity, but it must embody this. This being understood, the misconception is ruled out saying that Christian worship must be missionary or evangelistic. ' Justice is done to the theology of worship by stating that worship must include missionary or apostolistic elements. Worship has as its result the mission of God if it is "worship in spirit and truth."

It has been discussed that the primary function of the church is worship. Now it must be observed that when worship is neglected or degenerates into a lifeless form, the church's missionary outreach diminishes:

A church that is no longer missionary within its environment and gives only parsimoniously to help the poor, proves that the worship it celebrates is merely an empty formality. ${ }^{2}$

Such a church is in a lamentable condition for then it is solely self-directèd and self-centered. Whenever a church has itself as its center instead of its environment wherein it has been placed, then it is not even worthy to be called "church," for it repudiates its very nature and raison d'etre. Its ecclesiology has deteriorated into what is called "ecclesiolatry, "3 and its worship into idolatry,

lPease, p. 48.

${ }^{2}$ Paquier, pp. xviii-xix.

$3_{\text {A. R. Tippett, Verdict Theology in Missionary Theory }}$ (Lincoln, Ill.: Lincoln Christian College Press, 1969), p. 69. 
i.e. the worship of self. To be church and to be missionary are essentially the same thing. Worship, then, is the God-initiated means to keep church and mission in a healthy equilibrium. Indeed, "a worshiping congregation enters to worship and departs to serve." 1 Stated differently, there is a beautiful reciprocity between worship and mission.

Reference must be made to the Old Testament examples of individuals who first worshiped God and in their worship were simultaneously enabled to continue their worship relationship with God by serving Him. To mention just a few examples: Moses (cf. Exod 3:2-15, especially verse 12; Exod 4:18-23;5:1-3); Joshua (cf. Josh 5:13-6:21); Isaiah (Isa $6: 1-7,9-13$ ). The pattern of worship-mission is also shown in the New Testament. The never-changing God (cf. James $1: 17$ ) sends in Christ His faithful people into Jerusalem, Judea, Samaria, and into all the world (cf. Mark 16:9, 14-20; Acts 1:8). These few examples show that Christian worship must precede mission because where there is no individual or congregationai worship, there can be no commission and no sending. Furthermore, if the essence of worship is misconceived and misinterpreted, tragic repercussions on the mission endeavors of the church will be the result. ${ }^{2}$

'Segler, A Theology of Church and Ministry, p. 191.

${ }^{2}$ See Jack Hyles, "Ingredients of an Evangelistic Church," The Ministry 43 (May 1970): 21. 
Mission is the natural outgrowth of worship "in spirit and truth." God's people, by definition, are a worshiping and a serving community, rejoicing in and proclaiming salvation as it is in Christ, the Lord of the churcin. The proper sequence therefore, is worship followed by mission. To rephrase the last statement: after vision the Christian worshiper responds in mission to extend salvation to those sheep who are not yet of this fold (cf. John 10:16).

Hence, before God's people can be the messengers of God they must first of all attentively listen to the message that God is communicating to them in worship. In worship God is "in dialogue" with His people through the reading of the Scriptures, through the preaching of the Word, through prayer and blessing. God's faithful people are enabled to dedicate themselves and God sends them in Christ into the world as His messengers. Thus they become the imitators of Christ, "going about" and "doing" the gospel. It is said,

By its worship, the Church becomes conscious of itself . . as a diaconal community. The Church learns through its cult, and manifests thereby, that it does not exist for itself, and has no justification in itself. It exists--as did the incarnate Christ--for God and for men. 1

Genuine worshipers worship God in Christ, guided by the Holy Spirit, because they have been saved by grace and in dedication

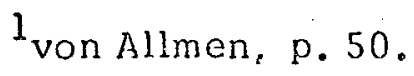


to God they leave the worship service as ambassadors of God, preaching salvation in word and in deed. For what the church owes to the world is just the gospel of Jesus Christ, the Lord of the church. 1

To recapitulate this particular paragraph in the words of JeanJacques von Allmen,

It is from the life of worship.. . that the Church spreads itself abroad into the world to mingle with it like leaven in the dough, to give it savour like salt, to irradiate it like light, and it is towards the cult . . . that the Church returns from the world, like a fisherman gathering up his nets or a farmer harvesting his grain. The only parochial activities which have any real justification are those which spring from worship and in their turn nourish it. ${ }^{2}$

\section{Worship-Mission Reciprocity}

The last sentence in the previous statement expresses the reciprocity of worship and mission. Mission is the outflow of worship "in spirit and truth." On the other hand, man cannot worship God while entering into His holy presence "empty-handed" (cf. Matt $25: 14-30)$.

The Christian who keeps the commandments of God and the faith of Jesus (Rev14:12) is participating in the preaching of the gospel (verse 6). He is practicing the good message in word and in

\footnotetext{
${ }^{1}$ See Barth, p. 208.

2 von Allmen, pp. 55-56.
} 
deed for the sole purpose that other people may also "worship him who made heaven and earth, ..." (verse 7). In other words, the fundamental goal of the church is not mission--how important mission is--but it is worship; while the goal of mission is also worship. There is then no conflict between church and mission in the context of worship, but there is a reciprocal equilibrium. Church and mission cannot do without worship, while worship is the prime move of church and mission. That is to say,"worship and evangelism flow into one another." 1

From this it is obvjous that a church which worships God "in spirit and truth" will also serve in response to God's commission. That is why the statement is made that "the best promotion to develop an active church is an effective program of divine worship. "2 Conversely, the best impetus to organize an effective worship program is a church diligent in mission work. That is to say:

True worship consists in working together with Christ. Prayers, exhortation, and talk are cheap fruits, which are frequently tied on; but fruits that are manifested in good works, in caring for the needy, the fatherles s, and widows, are genuine fruits, and grow naturally upon a| good tree. ${ }^{3}$

$$
\begin{aligned}
& { }_{\text {Hoon, p. } 28 .} \\
& 2_{\text {Pease, p. } 62 .} \\
& { }^{3} \text { Ellen G. White, Christian Service (Washington, D. C.: }
\end{aligned}
$$
General Conference of Seventh-day Adventists, Home Missionary Department, 1947), p. 96. 
Not a single individual whom God has called into His marvelous light (cf. 1 Pet 2:9) will be exempt from participating in the mission of the church. The church fellowship fulfills this commission only when it scatters into the world like seeds are scattered into the field and like the salt into the food (cf. Matt 5:13). When God's faithful people have fulfilled their mission during the week, they return as a fellowship at a certain place to worship God. This is the rhythm of the heartbeat of genuine worshipers and Christian worship. From the act of worship they go into mission and from mission they return to worship. I Stated differently still, the worship of God is extended in the service for Him, which, in turn, leads the faithful servants to the worship of Him.

The harmonious relationship between worship and mission

is suggested in the following:

No program, institution, or communication-satellite will do much good unless the world sees the gospel of Christ exemplified through His own people in their daily lives--in the way they have solved the daily problems of self and society, in their service to their fellowmen, and in the genuine Christian fellowship of the community of faith. ${ }^{2}$

\section{Worship and Eschatology}

Writing in the letter to the Hebrews, "Jesus Christ is the

${ }^{1}$ See Tietjen, p. 148.

${ }^{2}$ Oosterwai, p. 73 . 
same yesterday and today and forever" (Heb 13:8), the apostle is making an eschatological statement. In fact, the eschatological message of the letter to the Hebrews could be reworded as follows: Christ became the lamb of God and as such He suffered the wages of sin on the cross in the past so that men might have life everlasting, now and forever. He is the officiating high priest in heaven in the present so that when He comes again as King in the future, He gathers in all those who have been eagerly waiting for Him (Heb 9:28). The three different functions of the incarnate Sonl of God have all one purpose in common, i.e., full salvation for all those who accepted Him by faith.

Questions like "What is meant with the phrase, 'these last days'?" and "How does the phrase relate to worship?" are topics of the discussion which follows.

\section{Eschatou tōn Hēmerōn}

From the letter to the Hebrews (cf. 1:2) and from the first letter of Peter (cf. 1:20) it is clear that the end (eschatos) began with the coming of Christ in the flesh (Gal 4:4). From the other New Testament documents it is understood that the early Christians considered their own present as "the last days" (Heb 1:2). This conviction was based on the facts that (1) the Holy Spirit had been poured out on the church (Acts 2:17), which event was a fulfillment of the prophecy of Joel and of Christ Himself (Joel 2:28-29; Acts 1:8); 
(2) the days of the early Christians were evil days for there were scoffers, false christs, and false prophets, while the coming of the antichrist was expected (cf. $2 \operatorname{Tim} 3: 1 ;$ Jas $5: 3$ ); and (3) the early Christians lived in the hopeful expectation of the imminent return of the Lord of the church (cf. I Cor 15:26, 51-55; 1|Thess 4). The New Testament reverberates the Christological axiom that the eschatos had been ushered in already in the Christ event. 1 An attempt is now made to do justice to the word eschatos by interpreting it in the context of the Christ event in its totality; i.e., in terms of all three aspects of time in the life and ministry of Christ, namely, past, present, and future, and to see whether there is a relationship between this understanding of eschatos and Christian worship.

Eschatos and the Christ Event

Christian worship has eschatological' overtones. In the worship act salvation (forgiveness) is offered anew to God's confessing people. Salvation was ratified on the cross in the past so that those who accept salvation as it is in Christ can worship God in the present and in the future on the earth made new. "Divine worship is an eschatological event. Its whole procedure is a sort of echo of the

${ }^{1}$ Gerhard Kittel, "eschatos, "TDNT, 2:697. 
incarnation and the prefiguration of worship in heaven. "l

Thus Christian worship in the present moves the believer towards that perfect worship in the future. It is through Christ that the Christian worshiper was delivered from the dominion of sin and death and placed into the life in the Spirit. The salvific work of Christ during His incarnation in the past for the sake of repentant sinners has its redeeming effect in the present, so that the faithful worshiper may worship Godalso in the future (new earth). Christian worship, then, means: participation in the salvation prepared in and by Jesus Christ. In the past Christ died as the lamb of God (John 1:29; $19: 30)$ on the cross of Calvary; it was in the past that He was buried and arose from the dead (Luke 23:54-24:8), and it was in the past that the resurrected Christ ascended into heaven to continue His redemptive work (Acts 1:9). The Christian worshiper has taken part in these particular aspects of the Christ event, sin, was also buried, and was resurrected into the newness of life (cf. Rom 6:3-11). Now the worshipful believer participates also in the life and ministry of Jesus Christ who is standing at the right hand of God (Acts 7:56), as the high priest of the people of God, judging and justifying (Ps 50:6; John 5:22; Acts 17:31; Heb 12:23; Rev 14:6:7). It is in this presentness that the Christian worshiper participates in

$1_{\text {Jean-Jacques von Allmen, Preaching and Congregation }}$

(Richmond, Va.: John Knox Press, 1962), p. 32 . 
Christ's heavenly ministry, faithfully fulfilling G'od's mission on earth (Matt 25:34; John 14:1-3).

All this is the eschatological existence according to the New Testament. 'Stated differently, the Christian believer has been transplanted into the eschatological era (cf. 2 Cor 5:17; 1 John 3:2). This eschatology reverberates in Christian worship. The worship of God by the Christian believer is the participation in the one worldsaving and in the "once for all" sacrificed, buried, resurrected, and ascended Jesus, the Christ (John $1: 29 ; 19: 30 ; 20: 11$ lf; Acts 1:9;

Rom 3:10; Heb 9:26).

Christian worship, therefore, "recapitalizes the drama of salvation in the sense that it makes the past effectively present, joreshadows the future and glorifies the Messianic present." 1 Hence, Christian worship is "an eschatological phenomenon." 2 The is sue to which one has to address himself is, "What is the relationship between eschatos and the act of worship?" The Eschatological Act of Worship

To address the issue of eschatology! as related to Christian worship, a few examples of worship may suffice!

\section{\begin{tabular}{c|c} 
& 1 \\
1 & 1 \\
\hline
\end{tabular} \\ 2Ibid. See also Hoon, pp. 141-142.,}

Ivon Allmen, Worship: Its Theology and Practice, p. 36. 
A. Soteriological. Christian worshipers begin the act of worship with a review of their past since they have entered into the holy presence of God, realizing that they are unworthy. They continue their worship, guided by the Holy Spirit, with a rehearsal of their past in the act of confession. They move into their present, justified in Christ through faith and by grace (cf. Eph 2:8; 1 John 1:9) and are therefore prepared to give praise to God and to hear His Word. Finally, they offer their future life to their Creator and Redeemer, dedicating themselves to Him in willful service. Thus, three phases of time are clearly seen in Christian worship.

B. Ecclesiological. The Christian worshiper participates in the celebration to the total range of being. His participation is in the celebration of the past ("For all the saints, who from their labors rest"), he prays for the present ("Grant us courage for the facing of this hour"), and he expresses his hope for the future ("Come, thou long-expected Jesus"). 1

C. Christological. In the Lord's Supper, for example, the death of Christ for the salvation of the repentant sinner is visualized in more concrete form under the tokens of bread and wine. Thus, the past Christ event on Golgotha is made present in the act of worship,

$I_{\text {Bailey, p. } 70}$ 
and as often as they "eat this bread and drink the cup" the worshipers "proclaim the Lord's death until he comes" (i.e., future; cf. I Cor 11:26; italics mine). In other words, the Christian worshiper is participating in the "once for all" sacrifice of Christ under the tokens of bread and wine. ..... :

Christian worship, therefore, is not only based on what i.

Christ did in the past, nor alone on what He is/doing in the present, but also on His work of redemption which He will complete in the parousia. 1 Worship "in spirit and truth," then, also focuses on the visible kingdom of glory when Christ comes again. In these three phases Christ was, is, and will always be present. He was visibly present when He was on earth (John 1:11; Acts 2:32; 1 John 1:1-2). In the present Christ is in the midst of His faithful worshipers by His Spirit (Matt 18:20).

This "presentness" is fully materialized in the future when the faithful worshipers will see Him "face to face" (cf. 1 Cor 13:12), when He comes again as "King of kings and Lord of lords" (Rev 19:16).

It must be concluded then that there is an intimate relationship between worship and eschatology. Christiạn worship, therefore, is also eschatological. Faithful Christians worship not only because they have been saved by grace through faith in the past and, as such,

${ }^{1}$ See Ellen G. White, Testimonies for the Church, 6:368. 
work and worship in the present, but they also párticipate in worship because "in worship (they) appropriate God's future saving action in Christ." I

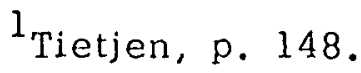




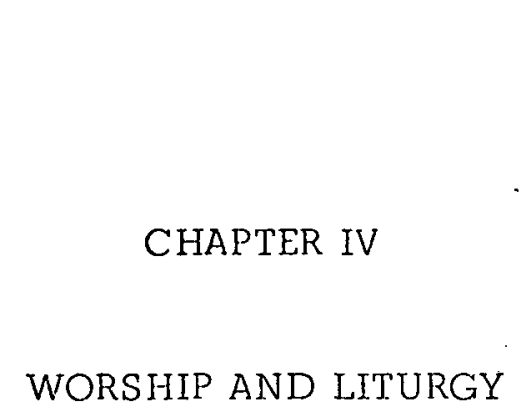

\section{Introduction}

Some Christians tend to become apprehénsive as soon as they hear the word liturgy. This is particularly the case when liturgy is used in the context of worship. This attitude seems to be the result of (1) a misunderstanding of the word, and (2) the identification of liturgy with the worship of the Roman Catholid Church and that of other high liturgical churches. Generally speaking, many Christians show quite a degree of defensiveness when confronted with the idea liturgy. objective way, examining historical as well as

An attempt is made here to approach this issue in an sources.

\section{The Meaning of the Word}

The word liturgy came to us through the classical Greek language. It must be understood that the Greek word Leitourgia is just a secular term. Etymologically, leitourgia means "an action of the people," The word is a combination of two nouns, leitos ("public") and ergon ("work"). Therefore, this compound noun 
originally refers to the performance of a public task imposed upon all who were citizens of Athens. It was simply "fulfilling the responsibility of a citizen, doing the expected service of anyone who was part of the city." I

The verb leitourgein also means "to assume public service by paying with one's person and money." 2 From this information it is clear that leitourgia was not performed by a cultic group of people (i.e., the priests) but simply by the public. This non-religious word expressed therefore " a secular service rendered to people within the context of society." 3 To suppose, then, that liturgy had originally some religious or ecclesiastical connotations is not in harmony with the historical facts. Therefore, how liturgy became a religious term needs further consideration.

The Jewish Greek-speaking translators of the Hebrew Scriptures adopted the Greek word for the Hebrew cultic term shereth, i.e., "to do service as priest." In this respect the following observation is made: "Leitourgia is always used (i.e.", in the LXX) of the ministry of the priests and Levites in and at the altar." 4

${ }^{1}$ Hardin, Quillian, and White, p. 33 . 2 Paquièr, p. 49.

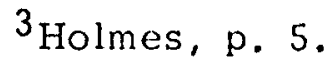

${ }^{4} \mathrm{H}$. Strathman, "leitourgeo and leitourgia in the LXX and Hellenistic Judaism," TDNT, 4:221. 
It should be noted that the original meaning of "service of the people" is taken over by the Hellenistic Jews but applied only to the cultic service of the priests and Levites. Further, the recipient of the leitourgia is no longer the people, but God.

Leitourgia was also used by the early Chinristians. Remarkable from the New Testament is the fact that the limited septuagintal application of the word is now applied to all Christians and not to the priests and apostles only. The reason for this is that all Christians form "a royal priesthood" and thus each individual Christian is a priest (cf. I Pet 2:9; Rev 1:6). As in the LXX, so in the New Testament: it is God who is the recipient of the service rendered by the spiritualized priestly ministry. This is implied in Acts 13:1-3, where the Greek word leitourgounton is used and translated with "worshiping" (verse 2, RSV) so that

It is no longer the people who are the beneficiary of the public service, but the Lord. The people, fon the contrary, assume responsibility for it. . . . The liturgy of the Christian Church is a religious service offered by the public to the Lord. 1

There is definitely a move backwards to the original meaning of the word, namely, the doing of service by anyone who is part of the city. In the Christian context this means the work of all the citizens of the kingdom of God, whether apostle, deacon, or fisherman.

$$
{ }^{1} \text { Paquier, p. } 49 .
$$


Only when liturgy is interpreted and applied in the New Testament sense must one do so Christologically. Only then is liturgy interpreted and applied with integrity.

\section{The Christology of Liturgy}

The most elaborate description of the ministry of Christ in behalf of His people is found in the letter to the Hebrews. The author's thoughts are deeply rooted in the outlook upon and the vocabulary of the Old Testament tabernacle services. Thus a magnificent elucidation is offered on the meaning of Christ's person (Heb 1-3) and work (Heb 4:14-10:26). A few illustrations may suffice for the Christological understanding of the leitourgia. It is stated: "We have such a high priest, one who is seated at. the right hand of the throne of the Majesty in heaven, a minister in the sanctuary. . . ." (tōn hagiōn leitourgos). Christ, being the high priest of the new covenant people, is the minister (literally, the liturgist). Moreover, His obtained liturgy is "as much more excellent than the old as the covenant he mediates is better" (verse 6). From the wider context (Heb 9:21-25) it is clear that Christ's ministry (leitourgia) is better because the sacrifices in Old Testament times had to be repeated continually. They could never attain to the goal of purifying the conscience. Yet all these sacrifices pointed forward to that unique, i.e., "once for all," sacrifice of Christ. Hence the terminology which 
designated the cultic service of the priest and Levites is transferred significantly to Jesus Christ who accomplished in Himself all the types of the Old Covenant. ${ }^{1}$ On the basis of His shed blood, Christ obtained a more excellent ministry (leitourgia). "His ministry is better because it is more effective, or, strictly, it alone is effective." 2

From Hebrews 9 it is understood that the Greek word translated with "worship" (verse 21) is leitourgias, 3 so that the inference is that the work of Christ in the heavenly sanctuary as the high priest "is a liturgical one... which involves purification and cleansing." 4 In addition, Christ is not the leitourgos for himself, but for His people on earth (Heb 9:19-21). Albert Hammenstede explains this as follows:

The liturgist, in the high sense of the word, is once and for all Christ the Lord. He has, as the only one for his people . . . brought a great sacrifice; he has made a sublime foundation: the leiton ergon of our redemption. This ergon is as much something objective ... . an action embracing heaven and earth, which Christ wants to live anew in us. 5 (Italics mine)

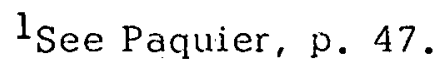

${ }^{2}$ Strathman, TDNT, 4:226.

3 See also Acts 3.3:2; they "were worshiping the Lord." ${ }^{4}$ Holmes, p. 5.

${ }^{5}$ Die Liturgie als Erlebnis, quoted by Paquier, p. 22. 
In the New Testament leitourgia finds then its deepest meaning in the ministry of Christ as the lamb of God (John 1:29) and as the unique high priest "after the order of Melchizedek" (Heb 6:20).

Having briefly discussed the Christology of the word liturgy, the attention must now be focused on the issue: "What is the connection between worship and liturgy?"

\section{Worship and Liturgy}

The worship of the Hebrew Christians, had its root in Judaism. When they assembled for worship in private houses they must have followed the pattern of the synagogue worship. These Hebrew Christians were not allowed to participate anymore in the worship services in the synagogue (cf. John 9:22). The early Christians brought the typical Jewish mode of worship with them into their own Christian fellowship gatherings for worship. From the letter to the Hebrews and from the letter of Paul to the Galatians, it is evident that these Christians maintained that particular worship pattern in their own worship gatherings. In Heb $1: 1-4$ there is a piling up of participle clauses which embody predications about God. This method was "characteristic of the liturgical style of the synagogue." I

In Gal 1:3 and 6:18 areother statements which show typical characteristics of the liturgical style of the Jewish church. Both

${ }^{l}$ F. F. Bruce, The Epistle to the Hebrews (Grand Rapids: Wm. B. Eerdmans Publishing Company, 1964)! p. 4. 
texts are formulae and sound as if they have been taken from the synagogue liturgy. It was the apostle Paul's intention that the epistle be read out in the churches of Galatia during their worship gatherings. These few verses, Gal 1:3-5, were written in the language of liturgy. ${ }^{1}$

Coming back to the original meaning ọf the word leitourgia, i.e., the work of the people, liturgical worship can be described as . the actions taking place in the service of the fellowship of believers in Christ when gathered for worshiping God. Actions like kneeling, joining hands, or raising them for prayer and blessing, standing, the reading of the Scriptures, the singing of hymns, bringing offerings, the breaking of bread, and the partaking of bread and wine, etc.

Since, then, the people of God do not consist of priests and ministers only, but of all the people, including priests and ministers, and since all the faithful followers of $\mathrm{Christ}$ are all "a royal priesthood" (1 Pet 2:9), justice is done to the originall meaning of leitourgia when it is applied to and includes all the worshipers "in spirit and truth." It is not without reason that in this context Jean-Jacques von Allmen siates that worship needs to be declericalized in many churches. 2

${ }^{1}$ See John Bligh, Galatians: A Discussion of St. Paul's Epistle (London: St. Paul Publications, 1970); pp. 65-66.

${ }^{2}$ See von Allmen, p. 16. 
Liturgical worsinip, by definition, means therefore,

All the people praising, praying, hearing, affirming, offering, as members one of another, are answering God's call to the whole Church to worship. 1

Whenever and wherever Christians assernble to worship God, liturgy takes shape because it is just the way which worship is done. Liturgy is the modus operandi. of worship.: Since worship creates liturgy, it is, therefore, "impossible to conduct a service without liturgy." 2 Worship cannot do without liturgy because the latter is the form in which the first is done. Hence, church worship and liturgy are interrelated and interdependent. ${ }^{3}$

In short, liturgy means that the people of God perform collectively the service to their Lord "in spirit and truth." It is the what-ness and the how-ness in worship and it "constitutes the articulation, the definition, the illustration of that event, that encounter with God, " 4 which is true worship. Liturgy, then, is non-existent when there is no worship. But it is the way in which worship is done by the who'e congregation in Christ in God's presence.

${ }^{1}$ Davis, p. 102. See also Paquier; pp. 51-54.

2 Pease, p. 51 .

3 Paquier, p. 49.

${ }^{4}$ Holmes, p. 1 . 


\section{- Worship, Liturgy, and Apostolicity}

The remark was made that to worship "in spirit and truth" one must experience salvation as it is in Christ. It is during the worship service that the Christian dedicates himself anew to God to enter the world as:a witness for Christ (cf. 1 Peth 2:9; Rev 1:6). Leitourgia has, therefore, a much wider |application than simply the worship service. To be a Christian means essentially to be a worshipful servant of God. In this sense Mártin Luther describes the Christian as "'a perfectly dutiful servant of alin, subject to all. " 1

There is "an indissoluble connection between worship, liturgy, and the apostolicity or mission of the church. Worship and mission have been discussed. The main emphasi's here is on the christological application of the original meaning of leitourgia to the life of the Christian. Leitourgia includes and embraces the whole life of the faithful Christian of which the worship act at a certain time and in a certain place, is but a part. Liturgy is, indeed, concerned with what the worshiper experiences and does during the worship service, but "of much greater importance is the cpncern that worship witnesses beyond itself to the whole life." 2

Describing the religious life of African people, John Mbiti

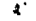

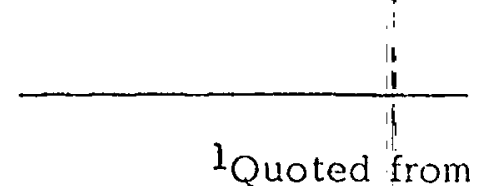

${ }^{1}$ Quoted from Aidan Kavanagh, "Religiolis Life and Worship," Worship 44 (April 1970): 200.

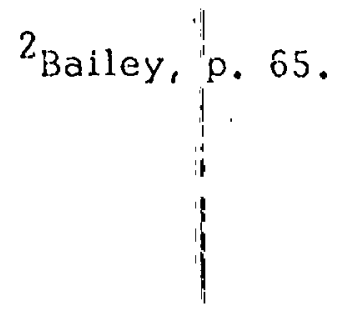


points out an essential aspect of religious iife which is in harmony with a Christian principle of worship:

It is not enough to embrace a faith which is confined to a church building or mosque, which is locked up six days and opened only once or twice a week. . . . The whole environment and, the whole time must be occupied by religious meaning, so that at any moment and in any place, a person feels enough to act in a meaningful and religious consciousness. 1

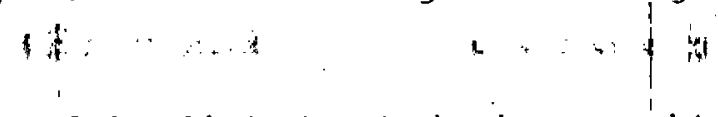

The life of the Christian is both a worshipful as well as a

liturgical life. The Christian's worshipful life is the expression of his continuous communion with God so that through him God is at work among men unto salvation (i.e., apostolicity; cf. 2 Cor 5:18-21), while the Christian liturgical life is his faithful service for God in behalf of his fellowmen (i.e., leitourgia). Both concepts overlap each other. Interpreting the concept "worship" and combining its meaning with the concepts of liturgy and mission, Hoon says:

The New Testament term "worship" (means) not only that which cultically happens at a certain time and place but as the Christian's total existence: in all his living the Christian inan is a liturgical man. . . The Christian's life in its totality is a liturgical life, and liturgically it can be thought of as much missionary as cultic. ${ }^{2}$ (Italics mine)

To say, however, that worship and lijurgy are identical is incorrect, because worship "in spirit and truth" initiates such

\section{$1_{\text {Mbiti, p. } 3 .}$}

${ }^{2}$ Hoon, pp. 17 and 31; see Segler, A Theology of Church and Ministry, p. 191. 
worshipful life within the believer. Worshipful life is demonstrated by a liturgical life, consisting of the daily tasks, duties, obligations, and responsibilities which the faithful christan faces and fulfills. Liturgical life, then, is the Christian's faithful work within church and society where' God has placed him because he is a worshiper of God. It is better to state that the Christian's 'worship and his liturgical life are interrelated, though distinct. Both may be subsumed under a common conception, that of the service of God. It is observed that worship and work are "forms of divine service, but they are not identical. Both are forms of leitourgia, liturgy, and work well done . . a service rendered to God." 1

To summarize: the faithful Christian worships God in a certain place and at a given time with God's pecple. Guided by the Holy Spirit he leaves the worship act and enters into the world to continue living the worshipful life. That life consists of the Christian's service (leitourgia) and his mission (and diakonia) in the name of Christ, who sent him (Matt 28:18-20; Rom 12:1-3; Eph 5:1-2; Phil $2: 14-16 ; \operatorname{Rev} 10: 11 ; 22: 17)$

From these observations the conclusion can be drawn that there is an indissoluble connection between Christian worship, liturgy, and apostolicity (mission). Christian worship cannot do

IAlden D. Kelley, The People of God (Greenwich, Conn.: Seabury Press, 1962), pp. 48-49. 
without liturgy, the nodus operandi, i.e., the way in which worship is done in a church building. This liturgy is just a small part of the total liturgical life of the Christian worshiper, which consists of his being sent by Goplite mission) and biscervice (diakōnia) for people in Christ's name. Hence, Christian worship, liturgy, and apostolicity are not strictly identical, but they are interrelated and interdependent. 


\section{CHAPTER V}

\section{WORSHIP AND SABBATH: A RECIPROCITY}

\section{Introduction}

In this chapter attention is focused on some aspects of the Sabbath which are unique with respect to worship. These aspects lend further support to what hà been discussed in terms of the worshipful and the liturgical life of the Christian. They also support the thesis that the teaching of the Scriptures about worship culminates in the teaching $c f$ the Sabbath. God's hallowing of the seventh day, man as a participant in the holiness of God, the culmination of the worshipful life, as well as Sabbath holiness as it affects the total life, are aspects which are discussed in this chapter.

\section{God Hallowed the Seventh Day}

The creation account (Gen 1) presents the order of the things which God created. In six consecutive days He created all the inanimate and animate things in the heavens and on the earth. Man, however, was created in the inage of God. And God saw everything He had made "and behold, it was very good." (Gen 1:31). The seventh day was the crown upon the creation week: it was the seventh day. 
There is a difference beiween the creation of the seventh day and that of the animate beings of the fifth and sixth days. We are told in Gen 1 that the Creator blessed the animate products of His creation, while such a blessing was not bestowed upon the inanimate things which God had made in the previous days. God's blessing upon the creatures that live in the water, in the air, on the dry land, and upon man included the procreative power which God endowed upon these living creatures so that they "be fruitful and multiply" (Gen 1:22, 28). The blessing upon man was superior. Man was not only to be fruitful and to muitiply, but he was also blessed with the authority to subdue the earth and to have dominion over all lower animate creatures (Gen 1:28). God appointed man as His steward and to execute rulership on earth (cf. Ps. 8:5-8).

On the seventh day God did something more than just bless that day. The Creator also "hallowed" that day because "on it God rested from all his work which he had done in creation" (Gen 2:3). There is progression in God's creative actions. He created the inanimate things but no particular blessing was pronounced upon these. God made the animate creatures and He blessed them all, while man received the greatest blessing. However, neither the inanimate created things nor the animate creatures, not even man, were "hallowed" by the creator God. The observation is made that there "is no reference in the record of Creation to any object in 
space that would be endowed with the quality of holiness." 1 In His providence, God did hallow something immaterial, something abstract, something universal. What God hallowed, in addition to giving His blessing to it, was time, i.e., the seventh day.

In blessing and sanctifying a day, He recognized time as a fundamental symbol of worship. The first worship symbol He gave to man was not a tree, a rock, a building, an altar, or an animal, but twenty-four hours, recurring every seven days. 2

For the first time in the Scriptures the significant Hebrew word gadosh is used and, remarkably enough, in connection with the seventh day of the week. In order to come to a better understanding of the meaning of God hallowing the seventh day, further attention must be given to this Hebrew word.

Qadosh means "set apart," "separate," while the Hebrew verb qadesh is translated "to be separate," "to set apart." Thus Gen 2:3 literally reads, "So God blessed the seventh day and 'separated' (i.e., wayqadesh) it" or " 'set it apart'." Qadosh conveys something like an atmosphere, i.e., something of an attribute of God. There are many instances in the Scriptures where the word gadosh is used. From a study of the word in its contexts it is evident that it is only

${ }^{1}$ Abraham Joshua Heschel, The Earth Is the Lord's \& the Sabbath (New York: Harper and Row, Publishers, 1966), p. 9.

$$
2 \text { Pease, p. } 9
$$


God who possesses holiness, because He is the Holy One. ${ }^{1}$ Since God is holy, He makes holy; He extends holiness, He "hallows" or calls into a holy relationship with himself. If there is anything in this creation that has holiness, that holiness is not something inherent, but it is holiness by calling or holiness bestowed. The tabernacle, the high priest, the people of Israel are illustrations of holiness by setting into a special relationship to the Holy One. Therefore, Gen 2:1-3 reveals that the Holy One endowed the seventh day with the quality of holiness, because "on it God rested from all his work which he had done in creation" (verse 3). For this reason the seventh day is called "the holy day of the LORD, honourable" (Isa 58:13).

God did not hallow or separate the seventh day for the sake of that day. But this day was the very first full day of Adam's life during which God manifested himself to man. From this it may be concluded that according to the Scriptures, holiness in time comes first ${ }^{2}$ and man's history with the Creator begins on the seventh day of creation, which later is called the Sabbath (Exod.16:29; 20:8-11).

Due to its conciseness, the creation account does not specifically mention the fact that man was holy when he was created. However, since man was created "in the image of God" and since

${ }^{1}$ Cf. Lev 11:44-45; 19:2; Josh 24:19; 1 Sam 2:2; Ps 22:3;

$99: 3,5,9 ; 1$ sa $5: 16 ; 6: 3 ; 57: 15$.

${ }^{2}$ See Heschel, p. 29. 
God is holy, it is understood that man reflected God's holiness. He was separated for a particular purpose (cf. Gen $1: 28 ; 2: 15)$. The seventh day, or the Sabbath, was hallowed so that man could mature in holiness by resting on the seventh day. The Sabbath, therefore, must always be conceived "as the first day in our relationship to God." I The holiness of the Sabbath precedes the growth in holiness of man, and thus precedes also the holiness of God's people. According to the origin of man's relationship to his Creator, it is God, the Holy One, who always comes first in man's life experience so that man can participate more fully in the holiness of God. The seventh day is the God-provided means to accomplish this.

\section{Man Partakes of Holiness}

The Creator did not hallow the Sabbath for the sake of the Sabbath. Sabbath holiness is intended for man. Differently stated, the Sabbath is the means by which God sanctifies man. The Sabbath is not holy in isolation from man, whether man was Adam in his sinless condition or the repentant sinner in his sinful state. But the Sabbath remains holy unto man. Stressing this relational aspect, the Scriptures say, "You shall keep the sabbath, because it is holy for you" (Exod 31:14). That means the Sabbath "is set apart" for the object, namely, "you." Hence, the object of the Sabbath and its

${ }^{1}$ Sakäe Kubo, God Meets Man (Nashvilie: Southern Publishing Association, 1978), p. 25 . 
holiness is man. Heschel says that "the Sabbath adds holiness to Israel." I This is a valid statement because "the Sabbath was made for man (Mark 2:27), and as such, the Sabbath is the sign of God's activity of sanctifying His faithful people (Ezek 20:10-20).

It (the Sabbath) points to Him as both the Creator and the Sanctifier. It declares that He who created all things in heaven and in earth, and by whom all things hold together, is the head of the church, and that by His power we are reconciled to God. For, speaking of Israel, He said, "I gave them My sabbaths to be a sign between $\mathrm{Me}$ and them, that they might know that I am the Lord that sanctify them"--make them holy. Ezekiel $20: 12$. Then the Sabbath is a sign of Christ!'s power to make us holy. As a sign of His sanctifying power the Sabbath is given to all who through Christ become a part of the Israel of God. ${ }^{2}$

We might add to this the following: Exodus 19:5-6 tells us that Israel is constituted by God's covenant as a kingdom of priests and "a holy nation." God's people is here declared holy. This declaration does not necessarily imply that the people of God were holy morally. This holiness is not to be understood, either, in terms of a static quality. But it is a relation to God in holiness which has the potential to grow. The Sabbath is the God-created means to fulfill that end so that God's faithíul pecple (i.e., holy people) will also become sanctified morally more and more in

${ }^{1}$ Heschel, p. 87.

${ }^{2}$ Ellen G. White, The Desire of Ages, pp. 263 -264. 
keeping the Sabbath day in fellowship with the Holy One. ${ }^{1}$

Though sin entered into the world, the Sabbath was not affected. This is evident from the history of salvation. God's first act of salvation for repentant sinners is to deliver them from the bondage of sin. God adopts repentant sinners as His children so that they can be led into the holiness of the Sabbath and thus experience more of God's sanctifying grace in fellowship with the Lord of the Sabbath (cf. Exod 3:16-17; 16:4-5;22-26). By delivering Israel out of Egyptian bondage, which is the type of the deliverance of God's people from the bondage of sin (cf. Exod 19:5-6 and 1 Pet 2:9-10), God called them to keep the Sabbath holy (Exod 16:4-30; $20: 8-11)$ so that they could realize that it was God who continued His work of sanctifying them (Exod 31:13; cf. Ezek 20:12, 20). Since God is a God of remembrance (Exod 2:24), He cornmands His redeemed people also to remember the Sabbath, to keep it holy.

According to Heschel, the Hebrew verb le gadesh in Exod 20:8 means, in the language of the Talmud, "to consecrate a woman," "to betroth her." 2 Israel in its relation to the Sabbath was as the groom is to the bride. The faithful groom will not desert nor

${ }^{3}$ See Hans K. LaRondelle, Christ Our Salvation (Mountain View, Calif: Pacific Press Publishing Association, 1980), pp. 58-59, $65,69-71$.

${ }^{2}$ Heschel, p.87. 
forsake his bride. He will keep, uphold, and support her. In return the groom will be blessed by his bride with her presence, help, and fruitfulness. Such may also be the relationship between God's faithful people today and the seventh-day Sabbath. God's people, keeping the Sabbath holy, receive blessings from God through the very Sabbath holiness. Sabbath holiness is therefore reciprocal. The true Sabbath keeper is being sanctified, and as a sanctified person, he keeps the Sabbath holy, for it is, indeed, holy unto him.

The Sabbath, then, presupposes a holy people. Individuals who partake in this holiness of God do so because they are enabled by Him to keep the Sabbath holy. Observance of the seventh day is much more than just the external compliance with the letter of a commandment. It is in essence the worshipful response of the redeemed to the Creator and Redeemer. He enters into that hallowed time and into the fellowship with the Holy One who hallowed the seventh day. This worshipful resporise of the believer is graciously answered by God in sanctifying him. The reciprocity of this holiness is expressed as follows: "Holiness of being must match holiness of time. Holiness of time must become holiness in time." I Stated differently, "In order to keep the Sabbath holy, men must themselves be holy." 2 Thus it is understood that men " are holy in proportion to their

$\mathrm{l}_{\text {Kubo, p. } 49 .}$

${ }^{2}$ Ellen G. White, Desire of Ages, p. 257. 
nearness of God." I. The closer His people walk with God, the holier they become. Hence, the seventh day Sabbath is the divinely created time during which God's people can have the closest fellowship and communion with Him so as to receive more holiness from Him, who is the Holy One himself. ${ }^{2}$

\section{The Culmination of Worshipful Life: Sabbath}

The command of Exod 20:8-11 was not only pronounced before the people of God to remind them that God was their Creator but also, as the context indicates, their Saviour. The Sabbath, therefore, stands also as the distinctive sign between the Creator-God who saves and the moral creatures who live in redemption.

It is the one commandment pronounced by God which provides and specifies the time for worship and for communion with the created things and with God himself. Thus the seventh day, the Sabbath, "stands for worship, meditation, study, prayer, communion, fellowship." 3

This day was instituted by God so that His people could be lifted above all earthly considerations to commune with Him. They lift

${ }^{1}$ M. L. Andreason, The Sabbath (Takoma Park, Washington, D. C.: Review and Herald Publishing Association, 1969), p. 57.

${ }^{2}$ See Elien $G$. White, Testimonies for the Church, 4:249. 3 Andreason, p. 28. 
their minds to things above and lay aside all that binds them to earth. In this way God sanctifies His people. Consequently, if one takes the Sabbath away he takes away from man the God-given opportunity to have full and free access to and intimate fellowship with the Creator, Saviour, and Sanctifier.

God has given man six days in which to do his own work and carry on the usual business of life; but He claims one day which He has set apart and sanctified. He gives it to man as a day in which he may rest from labour and devote himself to worship and the improvement of his spiritual condition. ${ }^{1}$

The redeemed one in Christ faithfully fulfills his daily tasks and duties throughout the week. His devoted concentration hinders him, so to say, from intimate fellowship and undisturbed communion with God. Yet his life and work comprise a worshipful, liturgical, and a God-and-man-serving life. ${ }^{2}$ In order to enable the faithful servant to devote himself completely and anew to God, the Creator set apart the seventh day so that He could sanctify him. The Sabbath, then, is the culmination of the worshipful life of the believer, not only as the celebration of creation and salvation but also as the day wherein the spirit of the believer is qujckened. Thus the seventh day "is not an interlude but the climax of living. "3

\footnotetext{
${ }^{l}$ Ellen G. White, Testimonies for the Church, $4: 249$.

${ }^{2}$ See chapter IV, "Worship and Liturgy."

${ }^{3}$ Heschel, p. 14.
} 
God did not leave man with the mere essentials for physical existence. He gave him a day in which he could build up and strengthen the povers of mind and heart. . . the Creator made a definite place in the life for divine worship. 1

Hence, the Sabbath "is not just a date, but an atmosphere," 2 and it."symbolizes God's presence with man."3 It means that the condescending, holy God is in the midst of His "holy nation," sanctifying them who worship a unique and holy God at a unique and holy time in a holy place. ${ }^{4}$

\section{Sabbath Holiness Permeates the Total Life}

A final question for which an answer must be found is:

"What effect does Sabbath holiness have upon the life during the six days of the week?"

That the Sabbath is not just relational to man but also to the six remaining days of the week is emphasized in Judaistic thought and agriculture. It is observed that "the Sabbath is the inspirer, the other days the inspired, " and that it is by means of the Sabbath holiness that the whole week is hallowed in Judaism. ${ }^{5}$ This religious

lOliver Fisher, et al., "In the Beginning," The Ministry 17 (September 1944): 22 .

${ }^{2}$ Heschel, p. $2 i$.

$3_{\text {Kubo, p. } 65 .}$

${ }^{4}$ Andreason, p. 56 .

${ }^{5}$ See Hoon, p. 112. 
conviction is.illustrated by an agricultural practice. It was the divine instruction that the first fruits of the harvest be dedicated to God (Exod 23:19). By so doing, the entire crop was "hallowed" to the great benefactor of Israel. Thus it is with the seventh day in relationship to the other six days of the week. The fourth commandment does not overlook the other six days. It says, "Six days shall you labor, and do all your work; but the seventh day is a sabbath to the Lord your God" (Exod 20:9-10). In other words, the commandment enjoins not only man's rest but also man's labor. It instructs God's people to both keep the seventh day holy and to work as a sanctified people, as a holy nation, during the remaining six days of the week. God's people are enabled to faithfully fulfill their service for Him during the six days because they keep the seventh day holy by His grace and by so doing are sanctified by God, who is holy. The Sabbath comnandment therefore "covers all time, all seven days of the week. " 1

When the worshiper "in spirit and truth" keeps the Sabbath, he not only renders his life which he lives during that particular day to God, but dedicates his entire life which he will live throughout the week to Him who sanctifies him on the seventh day. In this

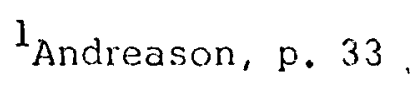


way the divinely sanctified time, the Sabbath day, "encompasses the totality of life." I

Christologically speaking, the holiness of the Sabbath is transformed by the Son of God in the life of the faithful worshiper into a sanctified life, i.e., a life dedicated to service in Christ throughout the week. That is the serving, the liturgical life, wellpleasing to God. Thus God's people respond to Him in faith by means of the worshipful life, a holy life, a life of obedience that is lived throughout the days of the week, looking forward to and longing for the Sabbath to come.

Therefore when God says that the Sabbath is a sign of sanctification. He means that it is a symbol that sets His people apart by their exemplary loyalty and obedience to His will and commandments. ${ }^{2}$

From what has been discussed in the context of the Sabbath, the conclusion may be drawn that what Christians are depends not only on what Christ means to them but also on what the Sabbath is to them. A religion that is limited to only a worship hour on a Sabbath morning is not positjoned to receive holiness, let alone to radiate that light of sanctification in the world wherein he lives, the reason being that such life is void of divine sanctity. Christians today do well to give heed to this thought:

$$
\begin{aligned}
& 1_{\text {Kubo, p. } 24 .} \\
& 2_{\text {Kubo, p. } 52 .}
\end{aligned}
$$


A mere form of Christianity is not of the least value. It is destitute of the satying powcr, having in it no reformative energy. A religion which is confined to Sabbath worship emits no rays of light to others. 1

The dynamic, the saving power in the life of the worshipful Christian permeates the world wherein he lives and works throughout. the week with the radiant light of divine sanctification. This light the worshiper "in spirit and truth" receives on the seventh day, the Sabbath, when, in close communion and fellowship with the Holy One, he reveres and worships Him. Thus the Christian life will be what God destined it to be: the light of the world; the worshipful, liturgical life to His glory and honor (cf. Matt 5:14; John 8:12).

${ }^{1}$ White, Testimonies for the Church, 5:339. 


\section{CHAPTER VI}

\section{CONCLUSION}

It is not sufficient and, therefore, not warranted to make theological statements about Christian worship solely on the basis of the meaning of the word "worship." The interpretation of the Hebrew and Greek words can assist in the improvement of the understanding of the meaning of "worship," but this may not be used as the only method of study. The main argument against such an approach is that the connotations which are provided by an etymological study of the words "worship," shachah and proskunein, are also relevant in and well applicable to the idea and practice of worship in other religions of the world.

The main criterion for the development and the verification of Christian worship, therefore, is the theological norm, that is, the Scriptures. Only when man's worship is subject to and in harmony with Sola Scriptura will the claim that his worship is "in spirit and truth" be authenticated.

Christian believers' worship, initiated by God himself, is the redeemed men's decent response to their Creator and Redeemer in the name of the Father, and of the Son, and of the Holy Spirit. Such 
worship is practiced at any time, in any place, and can be done under practically any circumstance. This is called personal worship.

As members of the body of the redeemed in Christ, the believers join the Christian fellowship when they gather to worship God at a given time and in a given place. Christ, the Lord of His church, is in their midst by the Holy Spirit, who guides and directs the redeemed people in their worship of God through Christ.

In Christian worship God's people are aware of the presence of the Holy One, the righteous Judge, and the merciful Justifier. They become conscious of their unworthiness. Guided and prompted by the Holy Spirit they confess their sins (individually as well as congregationally) and in faith receive justification, or the forgiveness of $\operatorname{sins}$.

God's people, in worship together in the presence of Him who sent Christ into the world, hear the message of God through the Scriptures and in the ministry of the Word. They are sent into the world so as to proclaim redemption and fellowship as it is in Christ. As a redeemed people they are sent out as a redeeming fellowship. Leaving the worship service, each individual member of the body of Christ participates in the ministry (leitourgia) of Christ, who is seated at the right hand of the Almighty, judging the world. God's people are in the world, serving God (mission) by serving (diakonia) the people of the world. 'This is what is understood with the Christian's liturgical, worshipful life throughout the week. 
The liturgical life of the Christian worshiper reaches its climax in the worship of God on the seventh day of the week, the Sabbath. God calls His people into His holy presence on the Sabbath day. God, who "hallowed" the seventh day, now sanctifies His people who worship Him "in spirit and truth." Thus the Christian worshiper is enabled to present his body as a living sacrifice unto his Creator and Redeemer for service. Being sanctified anew, the worshipers leave God's presence and enter into the liturgical life as followers, i.e., as co-priests, of Christ, who is their heavenly liturgist.

Thus Christian worship on the Sabbath day, which is the seventh day of the week, is carried over into the Christian's life and ministry from whence they enter into God's presence to worship Him "in spirit and truth." Such is the worship which comes from God, and it is the only worship which leads back to Him, to the glory of God the Father, the Son, and the Holy Spirit. 
PART TWO

TOWARD AN IMPROVEMENT OF WORSHIP PARTICIPATION 
CHAPTER VII

INTRODUCTION

\section{Statement of the Problem}

African people have a vast religious heritage and the African is a religious being. But even in this part of the world it would appear that African Christians behave differently outside the church building than they do during an act of worship. In other words, intentionality in worship is evident. Thus the question, "Why do people worship?" is legitimate in this ethnic setting.

The crucial issue of worship, therefore, whether in the Netherlands, in Nigeria, or in North America transcends cultural dispositions and barriers. The issue is not whether Christian worship is geographically, culturally, or situationally determined, but whether the theological principles of Christian worship are intelligently accepted and whether worship participation can be improved on the basis of an intellectual reassessment. Hence, the questions "Why do students at the Adventist Seminary of West Africa worship?" and "What can be done to guarantee greater worship participation?" are legitimate. This paper seeks answers to these questions. 


\section{Short History of A.S.W.A.}

Adventist miscionaries and evangelists in West Africa

realized that there had to be a program in addition to public evangelism to reach the minds of the younger people. It was recognized that education was needed to train strong men and women of firm principles for Christian service. They began to establish schools on the basis of the Adventist philosophy of education ${ }^{1}$ and, through the years, started several schools. The first Adventist institution of higher learning was founded in 1932, a teacher-training school under the leadership of W. T. B. Hyde.

The coming of regional self-government to Nigeria resulted in the establishment of a greatly increased number of schools under a free primary education plan. This was one of the reasons that Seventhday Adventists felt the need for a mission training school. As a result, the Adventist Training College was opened in 1955 and later developments in the Western Region included the establishment of the Adventist College of West Africa in 1959. The name.was changed in 1975 to the Adventist Seminary of West Africa.

Since 1959 hundreds of West African young men and women have attended and graduated from A. S. W. A. and the enrollment has increased from 110 in 1976 to 360 students in 1980.

${ }^{1}$ Ellen G. White, Evangelism (Washington, D.C.: Review and Herald Publishing Association, 1946), p. 107. 
Description of the 1978 Student Body

The 1978 student body was comprised of 205 sutdents from six different countries. There were 164 Nigerians and 33 Ghanaians, while Sierra Leone was represented by four students. There were two students from Liberia, one from Ethiopia, and one from the U.S.A.

One student was an adherent of the Islamic religion, while the remaining 204 students were Christians. Of the Christian stu-dents, 179 were Seventh-day Adventists, eight held membership in the Anglican Church, and two in the Roman Catholic Church; three were Methodists and eight students held membership in smaller denominations or church groups. Only four students did not indicate whether they held membership in a particular denomination. Thus, the 1978 A.S.W.A. student body was a multidenominational group of young people, 87.32 percent of which were Adventists.

It is interesting to note that of the 179 Adventist students, only thirty-five were life-time Seventh-day Adventists. Twenty-eight of them had been members of the Anglican Church, twelve had been Methodists; nine, Roman Catholics, and three had belonged to the Baptist Church. In other words, more than fifty of these students had at some previous time been members of churches or church groups other than the Seventh-day Adventist Church. From this it can be seen that many of the A.S.W.A. students had made certain religious commitments before coming to the seminary. It was expected that during a special week of spiritual emphasis students might make 
additional religious commitments, including, on the part of the interested ones, membership in the Seventh-day Adventist Church.

$$
\text { Goals of A.S.W.A. }
$$

As an Adventist institution of higher learning, A. S. W. A. has as its main goal the training of Adventist young people for Christian service in church and society. This school prepares students not only for the gospel ministry but also to serve as church administrators, secretaries, Bible workers, and business administrators. In addition to its ministerial program, A.S.W.A. offers education that may help young men and women better to assist their local pastors in the mission of the church, while maintaining their professional vocations in African society. Thus A.S.W.A. tries to materialize its Christian contribution for the uplifting of mankind in this part of the world.

\section{Religious Life at A.S.W.A.}

The Religious Life Committee of A.S.W.A. plans, organizes, and schedules worship services. Chapel services are scheduled for Monday and Wednesday mornings. The students are also encouraged to attend the evening worship services throughout the week. There are Friday and Saturday evening vesper services and two divine worship services on Sabbath morning. Branch Sabbath Schools are conducted in the surrounding area; students lead out in the Sabbath School and worship services. During Sabbath afternoons students may participate in personal evangelism in the town or stay on campus 
for lay activity instruction or Bible discussion groups.

Personal worship at A.S.W.A. is encouraged by the Religious Life Committee. There is a scheduled "quiet time" ( \pm 15 minutes) in the early morning after rising time to enable students to commune with God. The school administration encourages the students to worship God congregationally and privately.

Though there are many worship opportunities at A.S.W.A., one might ask: "What motivates the students to participate in worship?" "Why do West African students attend the chapel services?" "Do they understand the principles of Christian worship or are they present because a record of attendance is kept?"

Taking the cultural dimensions into consideration, one might ask the questions: "Is their worship attendance tribally determined or is it a purely personal decision?" "Is it a superimposed 'must' (tribal or school administrative) or is it an individual desire to worship God?" Finally, "Do the West African students understand the principles of Christian worship so that they worship 'in spirit and truth'?" Many Christians, including West Africans, frequently engage in their religious activities without thinking through why they are taking part in particular religious practices.

Obviously the outward form of Christian worship is not as critical as whether the principles of Christian worship are understood. As noted, there are many opportunities at A.S.W.A. to participate in worship activities. 
The Potential Role of A.S.W.A. for the Improvement of the Worship Situation

The potential role and function of A.S.W.A. as an institution of Christian education in West Africa to promote worship in the churches of the area is significant. The recommendations that follow are made with this in mind. The school must plan, prepare, and conduct worship programs in which the principles of Christian worship are explained and attempts made to apply these principles within the West African culture. At the same time this will promote a more. intelligent and, it is hoped, experiential participation on the part of those who attend the school. In an attempt to accomplish this, worship-emphasis weeks, worship workshops, seminars, prayermeeting series, and Bible-study groups in which the meaning of worship can be discovered and experienced are suggested. A worship committee should be organized to plan and coordinate such a program. What is taught could be grasped and followed by the students of A.S.W.A. who will cross the borders of the campus to carry these principles into the West African churches and society.

\section{Education in Worship is Essential}

To live is to learn. Christian worship must be learned in order for it to be worship "in spirit and truth." Ellen G. White's exhortation: "Educate, educate, educate"l is certainly applicable in

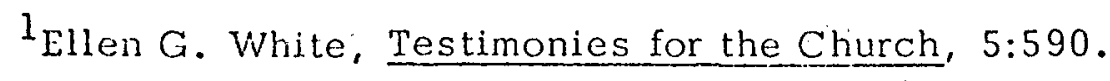


this field since Christian worship encompasses the totality of life. Education is, first of all, geared to the mind of man. Indeed, Christian worship is in the first instance an emotional response by the redeemed person to God. However, there is with this response a moral obligation of thinking through these emotional responses so as to order the concepts of Christian worship in a systematic way. 1 To assist in the development of one's understanding of Christian worship by means of education is essential. The urgency of such education is well expressed in the following words: "Renewal in Christian worship is best accomplished by ... an educational program. . . Education in worship is essential and long overdue." 2

Within the Adventist Church, a strong exhortation to teach God's people the principles of worship is made:

Unless correct ideas of true worship and true reverence are impressed upon the people there will be a growing tendency to place the sacred and eternal on a level with common things and those professing the truth will be an offense to God and a disgrace to religion. ${ }^{3}$

By means of educational programs the Christian may not only increase his theological understanding of Christian worship, but is also given the opportunity and the responsibility of becoming more involved in his personal Christian life, i.e. the worshipful, liturgical

${ }^{1}$ See Barclay, The Revelation of John, 1:153.

${ }^{2}$ Horn, pp. 144 and 153.

${ }^{3}$ Ellen G. White, Testimonies for the Church, 5:500. 
life as expressed in his participation in the mission and the service of God in the world wherein he lives. 1

Since A.S.W.A. is an Adventist institution where men and women of West Africa are educated for Christian service in the church and in the society of West Africa, we have an unusual opportunity to affect the worship experience of many Christians through these youth, educated in the principles of Christian worship.

\section{Potential Impact and Effect of Worship Education} in West African Adventist Churches

The A.S.W.A. students who have completed their course work and who have been exposed to one or more of the worship-education programs return to their home towns and villages. They reenter the West African society to take up their vocations. Some may return as church pastors and evangelists and church administrators. They have the opportunity to pass on what they have learned during their ministerial training. Others may assist the local pastor in promoting the worship of the local churches by becoming actively involved in the presentation of such worship improvement programs at the local church or district level.

One might envisage that churches will extend invitations to the A.S.W.A. administration to lead out in worship seminars during campmeetings, weeks of worship emphasis in local churches, or

\footnotetext{
${ }^{1}$ see Bailey, p. 21.
} 
worship workshops during ministerial conventions. Thus the Adventist churches in this area of the world may acquire increased understanding of what Christian worship is about and how the worshipful Christian life can be lived in their own culture. Worship education in West Africa may thus result in the capture of a new "vision" of worship and mission--a liturgical, worshipful life pleasing to God.

\section{Approaches to Education for Worship}

That worship education is essential and, in fact, long overdue has already been emphasized. It is obvious that the ultimate goal. of Christian worship is to bring about the "edification" or "the building up" of the church (cf. l Cor 14:26; Eph 4:12, 16) both in its qualitative and in its quantitative dimensions. However, the growth of the church as God's people and as a redeeming fellowship requires that their worship be done intelligently. God's people will not experience edification if they remain ignorant of Christian worship.

Ignorance does not increase the humility or spirituality or any professed follower of Christ. The truths of the divine word can be best appreciated by an intellectual Christian. Christ can be glorified by those who serve Him inteliigently. ${ }^{1}$

In order to edify the church in the scriptural principles of Christian worship, communication is indispensable. Communication is understood as the sharing among indivicuals of thoughts, ideas, and experiences. It is the exchange of concepts. In the Revelation

IEllen G. White, Counsels to Parents and Teachers (Mountain View, Calir.: Pacific Press Pub., Assn., 1943), p. 361. 
to John there is a strong emphasis on communication. God speaks and the created beings in heaven and His people on earth hear and respond (which act is, in essence, worship). The churches are cornmanded by the Lord to hear the vital messages (Rev 2:7, 11, 17, and $29 ; 3: 6,13$, and 22 ), and John himself is one who has heard a specific message from the Lord (Rev $5: 13 ; 7: 4 ; 9: 16,16: 5)$. In response to all these communications he says of himself: "I, John, am he who heard and saw these things. And when I heard and saw them, I fell down to worship." (Rev 22:8)

As will be explained in a later section, the first steps in a program of worship education conducted by the writer at A.S.W.A. were taken in a week of spiritual emphasis in which the worship of God was the theme and preaching was the major means of education. Preaching as a means of education, particuarly for worship, can readily be defended.

Preaching in the biblical sense is not the delivery of discourses, but rather à face-to-face or person-to-person speech. Differently stated, it is

- . a shared experience in which the given Word of God moves from the mind of God through the preacher as he listens and hears that Word in the sermon text and contemporizes it in human speech, to the mind of the worshipper as he listens and hears that given Word contemporized in 
in the sermon and which confronts him in terms of redemption and judgment. 1

God, then, communicates His Word from His mind through the Scriptures--the theological norm for Christian worship--then through the preacher to the listening worshiper. The preacher listens to God's Word and shares it with those who listen to him so that the worshipful listener hearing the Word of God in the Scriptures and sermon gives God a reverent reply. Then communication is complete. Within the context of congregational worship it may be stated that worship is ineiffective when there is no preaching of the Word. Within the context of personal worship it may be observed that worship is ineffective when the believer does not pay attention to what is being preached. Listening to the preacher makes communication a reality. Only then is the Word of God heard, an act of worship.

Thus, in Christian worship, to preach is to act and to hear is to act. Karl Barth writes:

In the Church to act means to hear, i.e., to hear the Word of God, and through the Word of God revelation of faith. . . . there exists no more intense, strenuous or animated action thian that which consists in hearing the Word of God. 2

On these bases, preaching was seen as a major instrument

${ }^{l_{C}}$. Raymond Holmes, "A Dialogical Evaluation of a Series of Eight Sermons Preached in the Bentor Harbor Church of the Seventhday Adventists from April 6 to June 1, 1974" (D. Min. Project, Ancrews University, 1974).

$$
2 \text { Barth, p. } 210 \text {. }
$$


to communicate the scriptural principles of Christian worship to the students of the Adventist Seminary of Viest Africa. The preaching was about God, who initiates Christian worship, and the fact that before the Christian enters a place of worship his Creator and Redeemer is already there. In the preaching of the series of sermons it was stated that it was not the worshiper who "invokes" the holy presence of God but that it is God himself who calls the worshiper into His holy presence. The believer, being aware of this gracious revelation of God's prevenient presence, gives God an appropriate response in his act of humble confession followed by adoration, praise, and thanksgiving, which are all part of worship "in spirit and truth." The worshiper hears the Word of God being preached and receives the message which God communicates to him through the ministry of the Word. The redeemed worshiper rededicates himself to God and enters into the world as a redeeming person, serving men by serving God, living the liturgical life. ${ }^{1}$

lsee Part One, chapters III and IV. 


\section{A PROGRAM OF EDUCATION IN WORSHIP PRINCIPLES FOR A.S.W.A. STUDENTS}

In this chapter recommendations for a program of education in public worship for A.S.W.A., as well as a description of the first steps which were taken in the implementation of such a program are presented.

\section{Theological Undergirding}

It is recommended that the following principles, distilled from Section I of this paper, be the basis of worship education for the A.S.W.A. student body:

God-initiated, Christian worship may be described as the redeemed person's response to his redeeming God in the name of Christ. Such worship is guided by the Holy Spirit to the glory of the Father in heaven. This response to the Creator ard Redeemer is (1) a worshipful reaction on the part of the individual Christian at any time, in any place, and under almost any circumstance and (2) a worshipful reaction on the part of the Christian fellowship of believers. The purpose of corporate worship is to give God praise and thanks, to confess sins and to receive forgiveness, to listen to the Scriptures and the 
ministry of the Word, to experience the rededication of the group to God's service. ' Congregational worship is limited to time and space but is done "in spirit and truth" when the effects of such worship are extended outside the church building to the world where the Christians live and work. As part of a redeemed fellowship, God's people leave the congregational worship act as individuals. They enter into the world and disperse like the salt of the earth to continue their worship in a liturgical life as individual Christians. As part of a redeeming fellowship, each worshiper in Christ is called to serve God in the world to which he is sent (mission), participating in the ministry of Jesus Christ (leitourgia) who is the high priest in the heavenly sanctuary and ministers before God on behalf of His people while the redeemed, as priests on earth (1 Pet 2:9-10; Rev 1:6), serve or minister (leitourgia) on behalf of the people of the world, beseeching them "be reconciled to God" (2 Cor 5:20).

God, who declared His redeemed people holy (Exod 19:5,6; 1 Pet 2:9-10), calls them into His holy presence on the Sabbath (Exod 20:8-11; Isa 58:13; Mark 2:27-28) to worship Him "in spirit and truth" (Johin $4: 24)$. During this worship on the Sabbath, which is the climax of their worshipfui life, their Creator and Redeemer bestows upon the worshiping believers more holiness (Exod 31:13; Ezek 20:12, 20) so

$\mathrm{l}_{\text {See Part One, chapter III. }}$ 
that they are enabled to reenter the world to faithfully serve Him.

\section{Recommendations}

Reference was made earlier to the interrelationship of preaching and worship and to preaching as a means of education for worship. In addition, other supporting means are suggested.

\section{A Worship Committee}

It is recommended that a worship committee be appointed as a standing committee of the school.

Purpose of the committee. The purpose of a worship committee is to plan and direct means and methods for the edification of church members (including student body) in their total worship life.

Members of the committee. To enable the worship committee to function properly a fair representation of the constituents of the A.S.W.A. church should be included. Taking into consideration that the church is a redeeming as well as a redeemed fellowship, a missionaryas well as a worshiping fellowship, ${ }^{1}$ members of this committee must be appointed accordingly. Members could include: (1) the head elder; (2) the head deacon; (3) the head deaconess; (4) the lay activities leader; (5) the youth leader; (6) the welfare leader; (7) the music director or choir leader; (8) a representation of the church constituents, 
and (9) the senior ministerial students of A.S.W.A. The latter should be invited, if not elected, for leading or learning purposes. This committee could be presided over by the A.S.W.A. or local church pastor. He might also be invited as the committee's counselor.

Function of the committee. The worship committee would be called into existence to plan and to recommend means or methods to edify God's people in: (1) the worship practices (so as to improve understanding of the nature of and participation in the worship services in the church) of the school and (2) its worshipful existence in the neighborhood where the A.S.W.A. church (or any Adventist church) bears its witness. The plâns and recommendations of the committee should be presented to the church board which, in turn, would be responsible for the implementation of the plans and recommendations as soon as these have been acted upon by the church board.

Some means or methods the worship committee could recom-mend are: (1) pericdic sermons or a sermon series on worship; (2) a worship seminar or workshop; (3) worship Bible-study groups; (4) worship prayer meetings.

An example of the use of preaching in worship education is dealt with in some detail in a later section. 
Worship Seminar/Workshop

At A.S.W.A. there are many facilities which most of the local churches in West Africa do not have. There are spacious rooms, chalk boards, a general assembly hall, a library, and some audiovisual aids. The facilities are ideal for seminars or workshops.

To gear a worship seminar/workshop for success, handouts must be prepared as teaching tools and communication devices. The worship committee of A.S.W.A., in close cooperation with the church pastor, might assume the responsibility of planning and preparing a program and materials. Following are some suggestions for handouts:

(1) a sheet of biblical data on "worship" with blanks to be filled in

(2) a sheet investigating the nature of "worship" (due to the vastness of the subject, several pages might be needed).

(3) an identification exercise containing questions designed to assist the group members in recognizing their own worship practices

(4) a sheet on which to give suggestions for corporate worship in the A.S.W.A. church or any other church

(5) a sheet on which to evaluate the worship seminar/workshop

(6) miscellaneous materials (for the participants to keep) which clarify and emphasize the nature and some of the practices of Christian worship

Methods for conducting a seminar/workshop. It is suggested 
that attendees be divided into small groups of about six to eight persons each. The leader of each group could be a member of the A.S.W.A. worship committee and/or a senior ministerial student. To activate the intra-group relationship and diminish possible negative attitudes, attendees should be encouraged to share particular experiences. For example, the groups could discuss "What was the most important thing that took place in my life ten years ago?" or "What" is the most valuable item in my pocket or purse?" Usually all the groups accept involvement in this exercise. Such procedures break down possible fears and preconceptions and serve as "ice-breakers." After ten to fifteen minutes, a brief summary of the entire seminar/ workship groups' responses can be given.

Immediately after this exercise, a ten-to-fifteen-minutes introduction might be given in which the issue of "worship" as it relates to the Seventh-day Adventist church is discussed. The introduction could lead the participants directly into a thirty-minute scheduled Bible study of the principles of Christian worship. Sheet (1) could be used for this exercise. The Bible study should be followed by a short break. After the break, sheet (2) is distributed for an investigation of some of the aspects of the nature of worship. The purpose of such an investigation is to impress upon the seminar/ workshop participants the biblical principles of Christian worship and to compare what they have discovered thus far with the present-day situation in Adventist church worship. It is recommended that fifteen 
mirutes be allowed for this investigation. After fifteen minutes, another twenty-five minutes (or more) can be scheduled for the com-parison of insights within the small groups. Then some time must be spent in sharing the ideas with the entire seminar/workshop group. This approach usually develops into a lively discussion within the groups and within the seminar in plene.

Following this, sheet (3) could be distributed so group members can try to identify and specify their private and corporate worship practices. Before the group members enter into this exercise, they might sing an appropriate hymn together and conduct a very short devotion. Each group can be asked to function as a prayer band, praying for spiritual insight in this matter of personal and corporate worship so that their worship may become what it ought to be, namely, "in spirit and truth." Fifteen minutes are allowed for this exercise. Then the group members, seeking insights, responses, and confirmations from the group, can express their personal convictions, working under the supervision of the group leader. At the end of this part of the program some time is taken to share in a more general way what has taken place within the groups and what degrees of worship invoivement have been reached thus far.

Between the morning and afternoon sessions an agapē-meal could be a very effective means of deepening fellowship.

During the afternoon session, sheet (4) is distributed to be filled in and discussed within the groups. After thirty to forty 
minutes each group presents its remarks and suggestions for discussion in pleno. A well-appreciated part of a worship seminar/workshop program might be a worship-related film or a serjes of slides on liturgy, worship, church architecture, mission, etc.

The A.S.W.A. worship committee should provide seminar materials for the participants to keep for their private files as an encouragement for further personal study and review. At the close of this small-group event on Christian worship, sheet (5) is distributed for evaluation purposes.

Generally speaking, worship seminars like the one suggested here are well appreciated by church members. They are experienced as a means of tying Seventh-day Adventist believers closer together so that they are better able to worship God, their Creator and Redeemer, by witnessing as a redeeming fellowship.

\section{Bible-study Groups}

The A.S.W.A. worship committee can plan and recommend worship education in the form of Bible-study groups. As noted earlier, the study of the Scriptures during the worship seminar/workshop should be made an important part of edifying the A.S.W.A. church in Christian worship. Of course, Bible-study groups can be planned and organized without necessarily conducting a worship seminar/ workshop.

To be successful, the worship Bible-study groups (WBSG) 
must be organized on a voluntary basis. Therefore, the worship committee might prepare registration forms to be distributed. All those who register are invited to come together for a general meeting during which the program is presented and discussed. After that the individual groups could meet on a rotation basis in the homes of staff and faculty members or in the assembly hall at a regular time each week. The organization of the WBSG would fall under the responsibility of the worship committee, supervised by the A.S.W.A. pastor or the lay activities leader. Bible study guidelines should be prepared. In addition to the senior ministerial students, elders, deacons, and deaconesses should be instructed and assigned to preside over the study groups in their search for the meaning and practice of Christian worship.

The study of a particular aspect of worship by the groups should not be conducted in a monologue form. Each group member should be allowed to express himself or herself during the study of the Bible passages.

To provide for a systematic approach in the Bible studies the general outline as presented in Part One of this paper is recommended. In addition, there are Bible-study outlines on the subject in The Ministry which can be used. ${ }^{1}$ Audio-visual aids such as slides,

${ }^{1}$ See Werner Stavenhagen, "Worshiping God in His Sanctuary," The Ministry 28 (May 1955): 40-41. See also "True Worship," The Ministry 30 (July 1957): 30-31 and "False Worship," ibid., pp. $31-32$. 
pictures, and other means, prepared by the worship committee could be effectively employed. Illustrations of Old Testament altars, sacrifices, the tabernacle and its services, Christ, the Lamb of God, the heavenly sanctuary and Christ's ministry as the high priest, and the three angels' messages (Rev 14:6-11) would help strengthen the Bible students' understanding of Christian worship and enhance group interaction.

Although not all church members will participate in the WBSG program, it can still be an effective means of education for worship in the A.S.W.A. church. In addition, A.S.W.A. students who have been exposed to or have participated in the program would be in a position to make suggestions and recommendations for such a program in their local churches in West Africa. They could in turn lead out in such worship-enrichment programs in their churches.

\section{Worship Prayer-Meeting Series}

Another method for promoting the total worship of a local church is the midweek prayer meeting. It is recommended that the A.S.W.A. worship committee present such a program to the church board for approval.

Generally speaking, the prayer meeting is an opportunity for any local church, including the.A.S.W.A. church, to have a special type of learning experience. Attendees are usually those who have a special interest in the program. The rather informal atmosphere is an 
environment in which dialogue flourishes. Group interaction is usually higher and less formal than at other worship services. Moreover, the weekly format is conducive to a presentation of a series of worship studies.

In cooperation with the worship committee, the A.S.W.A. church pastor, or the person who has been invited, would lead out in the program. A worship series would be prepared and presented. This program could be conducted each Wednesday evening for a quarter. To improve its chance of success and its potential effects, this series of lessons should be presented in a class instead of a sermon format. Such audio-visual aids as an overhead projector and/or slide projector, chalk board, pictures, etc. can be used very effectively. For reviewing purposes the worship committee could, in cooperation with the person who leads out in this series, prepare outlines of the materials to be distributed among the attendees for further study pur-poses. Materiais might be taken from Part One of this paper, from the sermon outlines, and from the tables lisied.

The final section of this paper reports the initial steps taken by the author at A.S.W.A. to implement his recommendations for employing preaching as a means of education for worship. The school's annual Week of Spiritual Emphasis was dedicated to this emphasis. 


\section{A Week of Worship Emphasis}

The author submitted a request to the Department of Religion at A.S.W.A. to conduct a Week of Spiritual Emphasis during which the attention of the students would be drawn to the principles of Christian worship. The department was asked to study the plan and make recommendations to the A.S.W.A. Executive Board. I

The Executive Board, realizing the need of a better understanding of Christian worship, took an action to implement the plan. ${ }^{2}$ In this way full authorjzation was received to prepare, organize, and conduct this program at A.S.W.A. A means to measure the students' comprehension of worship after that week was developed. The preparation of tweive sermons based on a study of the theology of Christian worship was the next phase of the project. Hymns and Scripture readings were selected, special music arranged, and special announcements designed to draw the attention of the students to this important week.

The Sermons

The intention was to communicate to the students the scriptural meaning and description of worship. A series of sermons in which a simple theology of worship was developed was prepared with the goal of edifying the students in their worship of God. The pattern

$1_{\text {See appendix } A}$.

${ }^{2}$ See appendix $B$. 
development as explained and shown in Part One of this paper was closely followed.

During the month of December 1977, twelve sermons were developed for which the following titles were chosen: ${ }^{1}$

Sunday evening, Feb. 12: RELIGION LIVED

Monday morning, Feb. 13: WORSHIP! WHAT DOES THAT MEAN?

Monday evening, Feb. 13: GOD TAKES THE INITIATIVE

Tuesday morning, Feb. 14: GOD'S ACTION, HUMAN REACTION

Tuesday evening, Feb. 14: THE CENTER OF WORSHIP, CHRIST

Wednesday morning, Feb. 15: IN SPIRIT AND TRUTH

Wednesday evening, Feb. 15: SALVATION AND WORSHIP

Thursclay morning, Feb. 16: CHURCH AND MISSJON: WHERE WORSHIP?

Thursday evening, Feb. 16: LITURGICAL CHRISTIANS: YES OR NO?

Friday morning, Feb. 17: HEAVENLY SEQUENCE

Friday evening, Feb. 17: THE BATTLE ABOUT WORSHIP

Saturday morning, Feb. 18: CLIMAX OF WORSHIP: SABBATH

The Program

In order to guarantee greater involvement on the part of the students in the presentation of this worship program, the assistance of the A.S.W.A. music director was requested. A meeting was held and the titles of the sermons were given to her so that she could

${ }^{1}$ See appendix C. 
assign and audit particular musical arrangements for each sermon. Faculty members as well as students were invited to contribute in this way. African people love to sing and, in addition to the participating individuals, there were seven singing groups which contributed to the success of the program. In harmony with the theme of the week, inspirational statements on music and worship taken from the writings of Ellen G. White were selected and read. This was done as encouragement for those who made musical contributions and to stress the truth that singing and music are as much acts of worship as is prayer. ${ }^{1}$

\section{Students' participation}

To help the students prepare for this special week, a series of special arnouncements was prepared and each announcement was placed on the notice boards in the buildings. These announcements had been planned in such a way that they contained an increasing challenge and appeal to prepare for this week of worship emphasis. The first announcement was published on January 30, 1978, the second on February 1, the third on February 3, and the fourth on the 6 th, while the last announcement was placed on the notice boards on Friday morning, February 10.

${ }^{I}$ Ellen G. White, Education, p. 168. 
Liturgical framework

The twelve sermons were delivered within a particular liturgical framework. The general sequence of each service was as. follows: (1) hymn; (2) prayer (a student); (3) Scripture reading (a student); (4) special music (students or faculty); (5) quotation and application (from the writings of Ellen G. White); (6) sermon; (7) prayer session (students, prayer groups, or closing prayer); (8) hymn; and (9) benediction.

\section{Attendance}

The A.S.W.A. chäpel, originally designed as a cafeteria, has a seating capacity of about 230. During the Week of Spiritual Emphasis additional chairs had to be brought in so that other attendees might also be seated. In addition to the students (205), faculty members and their spouses attended as well as staff members and several spouses of the married students. It was estimated that an average of 250 persons attended these worship-emphasis meetings.

\section{Sermon outlines}

The theme of the week was "You . . . and worship." As has been mentioned, the purpose of this week was (1) to instruct the students, as much as possible within the alloted time, concerning the meaning and majesty of Christian worship and (2) to encourage them to put into practice what they might learn from the sermons during the week. Samples from the twelve sermons are presented in outline form 
below. I It should be noted that these sermon outlines closely follow the sequence and development of the theology of Christian worship as discussed in Part One of this project. Space limitations prohibit the inclusion of full-length sermon manuscripts.

Sermon Outline 1: Religion Lived

Scripture Reading: John $14: 6$ and Rev 14:6-7

I. a. Worship is the most important phenomenon in man's life

b. African people are recognized to be religious. "To live is to to be caught up in a religious drama" (Mbiti, p. 3).

c. Why worship? Needs a theological answer, not a cultural, anthropological, or sociological answer

d. The church's mission can be improved by reforming its worship; not in terms of form, but of the understanding of worship (5'T 500; Hoon, p. 27)

e. Here is the opportunity to learn more about true worship

II. a. The Scriptures; special revelation tells what worship is Hymn 212: "I Love the Sacred Book of God"

b. True worship is in harmony with that Word of God

c. No man can truly worship God in the way he himself sees fit.

d. John 14:6 and Rev 14:6-7. Worship is theocentric; God is the center. Christian faith means obedience to the will of God

e. Worship is indeed the Christian's main concern. Rev 14:7 Adventism is the God-initiated and God-guided worship reformation movement

f. The books of Daniel and Revelation show that the essence of man's life is worship

1. Dan 7:9-10,13-14. Indirect invitation

2. Rev 14:6-7. A direct invitation to worship

III. a. God's people are called to be honest demonstrators of religion without being or becoming "religious".

b. Adventisin is today's demonstration of Bible reiligion lived.

c. Rev 14:7 can be done only on the basis of Rev 14:6

d. To show what true worship is and how it is practiced Ministry 39: 47 (October, 1958)

e. The Adventist way of life is a way of worship, which is religion lived

${ }^{i}$ For the remaining sermon outlines see appendix $D$. 
IV. Conclusion:

Follow us this week in an excursion through the magnificent building of worship. I would like to guide you through all its majestic and spacious rooms. You may get the taste and the feeling of worship. It is all free. You will never forget what you have seen and what you have heard. You, too, will develop a desire to live that religion which comes from God and which leads you back to Him. That is what worship is intended to be. Follow me...

Sermon Outline 4: God's Action and Human Reaction Scripture Reading: Gen 1:1 and Exod 20:2

I. a. True worship is also a God-man interaction

b. When God speaks, something happens; there is action Gen 1:1 and Ps 33:6, 9; Gen 3:15 and Gal 4:4; Exod 20:2 and 1 Pet 2:9-10; John 1:1-3, 14; and Eph 2:8

c. Worship is the believer's participation in God's action

II. John 3:16 demonstrates one of God's actions

a. Before vie came to this place God was already here. The awareness of God's presence here and now enables us to produce reaction--adoration, confession, thanksgiving

b. 1. Such reaction is called response, which is worship

2. It is a double action: God's action--man's action-interaction. Worship is something done rather than something spoken. 1 John 4:10; God loved first, now we love

3. Worship is not entertainment. In worship, God's people act toward Him consciously and intelligently which is in essence a reaction to what God has already done

c. Illustration. Isa. 6:1-6. God acts and Jsaiah reacts Note God's action ( $v$. 5) and then the prophet's reactions This is what is called worship-interaction. True worship is really interactive, isn't it.

d. Attention, that is, mental activity is fixing an idea in the center of consciousness and keeping it there. Such attention turns physical/mental action into worshipful action: adoration, confession, praise

Karl Barth: "Ir the church to act means to hear, i.e., to hear the Word of God, and through the Word of God revelation and faith." "Blessed are they that hear, and who keep" (cf. Rev 1:3)

e. Worship is also two-way speech, a dialogue. However, God Himself begins the conversation. When we listen attentively, 
we can onswer Him decently. That is worship. G. Davis: "God speaking to his creatures and his creatures making a decent reply to hirn"

III. Conclusion

Are you willing to make such an appropriate reply to God? Do you begin to realize what worship essentially is? Are you learning the meaning of worship "in spirit and truth" How important it is to pay attention to God's presence now! Do you desire to become increasingly aware of God's love? Is it your wish to respond more and more to God in worship? God, the Creator and Redeemer, is doing His part. What will be your reaction. Would you, too, like to give Him a decent answer? And worship Him. . ?

Sermon Outline 7: Salvation and Worship

Scripture Reading: Exod $5: 1-3 ; 8: 1 ; 9: 1$

I. Nobody can truly worship God unless he has been saved in Jesus Christ. To illustrate: Abram (God's initiative!) Gen 12:lff. How often did Abram worship God? He built many altars to worship God. Last altar; Gen 22:8; Heb 11:17f. The people of Israel were delivered (God's initiative!) for worship purposes: Exod 5:1-3; $8: 1,20,27 ; 9: 1,13 ;$ Ps 105:43f

II. Application to our present-day worship of God

a. In worship there is a double revelation, as has been said: the holy and pure God and the unholy, impure man--the sinner 1. Isa 6

2. Acts 9

Result in 1: "Woe is me!"; result in 2: "Wretched man that I am." See Ps 90:8

b. Not to enter into God's presence means not to receive true self-revelation; no consciousness of sin; no confession

c. In worship God is not only the righteous Judge but also the merciful and righteous Justifier! "It is the mingling of judgment and mercy that makes salvation complete." SDA-BC, vol. 5,1153

Christ came into the world not to condemn, but to save. John 3:17. That is why the Son of God became Son of man! God is dealing with sin and sinners in a way the sinner himself can never deal with himself.

d. In worship God offers anew justification, forgiveness of sins, salvation so that His child can vorship Him "in spirit and 
truth." What a God! What a Saviour! What a life is awaiting all who desire to truly worship!

III. Real life is received in worship

2 Cor 7:10; Is a 6; Rom 7:24

By what means? Confession, prompted by the Holy Spirit. John $16: 8$

"If we confess our sins, He is faithrul and just . . " I John 1:9

That is really what it is: GOOD MESSAGE; GOOD NEWS; GOSPEL!

". . . the highest worship in the Gospel is the desire to receive forgiveness of sins, grace, and righteousness." (Augsburg Confession)

All this is available in true worship

It is your and my God who is ready to justify IF . . .

If He is allowed to forgive us our sins and cleanse us from allour unrighteousness IF ...

IF we . . confess

Grady Davis, "The moment I face God . . ."

Now this is what the Bible says: worship God "in spirit and truth"

Sermon Outline 10: The Heavenly Sequence

Scripture Reading: 2 Cor 5:17-20; Rev 1:5-6

I. To worship God "in spirit and truth" one needs first of all the salvation experience; Ps $22: 22 ; 149: 1$. From there the Christian goes into the world as witness for Him; 1 Pet $2: 9$

II. The relationship between leitourgia and witriess

a. The meaning of liturgy is broad

1. Liturgy means much more than just divine worship service

2. It includes the work of the people; service by the people for God

3. Luther; a Christian is ". . a perfectly dutiful servant of ali, subject to all". (Luther's Works, 31:344)

4. Christ is our Liturgist in heaven; His people, servants on earth, His liturgists

b. Worship is a very comprehensive word

1. It is not only personal communion with God

2. It is not only the fellowship of believers in worship (public)

3. It is also taking worship into the world--MISSION

c. The Christian's life is a liturgical life

"The NT term 'worship' (means) not only that which cultically 
happens at a certain time and place, but also as the Christian's total existence: in all his living the Christian man is a liturgical man" (Hoon)

1. Phil 2:7, 17; contextual emphasis: Christ, the Servant!

2. Rom 15:16: Paul, a minister of Jesus Christ (leitourgos)

3. Therefore 1 Pet 2:9-10 and Rev 1:6: God's people!

d. Our service; our liturgy

1. Rev 14:6-11.

2. The Advent movement is a WORSHIP REFORMATION MOVEMENT

3. Patriarchs and Prophets, p. 528: "In maintaining His public worship..."

4. The genuineness and integrity of Adventists' worship and liturgical life is shown only if their worship is a true reflection of what Christ, the heavenly Liturgist, is doing in the heavenly courts

III. To what extent is the Adventist worship service a reflection of the message "for the hour of judgment has come"?

The attitude witr which we leave the worship service:

a. "Well, that was that! It is finally over; fine!" or

b. "Thank you, Lord; I am yours. I go where You want me to go!"

c. Rephrase Desire of Ages, p. 161. The liturgy that comes from God is the only liturgy which will lead to God

d. Do you worship God only on the Sabbath morning?

e. How will you survive when, probably in the near future, the battle about worship is out in the open? At whose side will you stand?

f. Either "worship God and serve Him" or worship the other who is essentially yourself under the dominion of sin, and slavishly serve him

g. Genuine worship always leads to better service, liturgy, to a more meaningful Christian life and ministry. Come, and let us worship Him. . .

\section{Results of the Worship Emphasis Week}

The worship emphasis week at A.S.W.A. was an attempt to improve the worship situation by means of this series of sermons which the Executive Board granted permission to be preached during 
twelve consecutive worship sessions from Sunday evening, February 12, through Sabbath morning, February 18, 1978. It remains to be determined whether this attempt reached the objectives for which it had been designed.

\section{A Questionnaire}

On Sunday, February 19, a questionnaire, consisting of two sections, was distributed to the students. ${ }^{1}$ Section I contained questions regarding frequency of attendance during the Week of Worship Emphasis, the students' understanding of worship, their personal. reactions to the worship series, and their willingness to put into practice what they might have learned during the worship-emphasis week. Section II called for a reaction to specific concepts of Christian worship which had been explained the the twelve sermons and with which the respondents could now indicate their agreement or disagreement:

Section I of the questionnaire

The overall picture presented by the actual scores each of the questions in this section received was positive. Attendance was consistent on the part of almost 73 percent of the students. The 34 students who had not been able to atterid all twelve meetings had, nevertheless, been present an average of nine to eleven times.

\footnotetext{
${ }^{1}$ See appendix E, including the scores.
} 
Almost all respondents, i.e., 123 (a little more than 98 percent), indicated that they had gained a better understanding of Christian worship during the week. The students, of course, were well accustomed to taking notes. Seventy-three students marked that they had taken notes on the subjects presented.

An open-ended question gave opportunity for responses regarding possible values and benefits of the week as well as the opportunity to offer suggestions. It was hoped that this would help determine whether the views as expressed in these written reactions might match, in general, the responses to the specific worship statements listed in Section II of the questionnaire.

In general, it would appear that the Week of Worship Emphasis helped the students in their reassessment of the concept and practice of Christian worship. The question remains to be answered, however, of whether the responding students had indeed made progress in their understanding of worship, whether certain changes had taken place in their attitudes toward worship, and whether they had experienced spiritual growth.

\section{Section II of the guestionnaire}

The statements on worship in tabie 1 were derived from the theology of Christian worship which was discussed in Part One of this paper. Statement 1 was derived from the "Introduction" and the chapter entitled, "A Study of the Word 'Worship." Statements 2 and 
TABLE 1

TABULATION OF QUESTIONNAIRE, SECTION II

\begin{tabular}{|c|c|c|c|c|}
\hline No. & Contents of the Statement & Yes & No & Unans. \\
\hline 1 & $\begin{array}{l}\text { Any person can worship God as he thinks } \\
\text { is most suitable to God }\end{array}$ & 23 & 100 & 2 \\
\hline 2 & $\begin{array}{l}\text { Worship done in a church buildirig is just } \\
\text { a part of the individual's worshipful life }\end{array}$ & 118 & 4 & 3 \\
\hline 3 & $\begin{array}{l}\text { Worship and liturgy are, in essence, } \\
\text { identical }\end{array}$ & 112 & 7 & 6 \\
\hline 4 & $\begin{array}{l}\text { One can worship God only when he has } \\
\text { become aware of the existence and } \\
\text { presence of God }\end{array}$ & 100 & 22 & 3 \\
\hline 5 & $\begin{array}{l}\text { Worship presupposes that God, and not } \\
\text { the believer, always takes the initiative }\end{array}$ & 102 & 20 & 3 \\
\hline 6 & $\begin{array}{l}\text { Only in Christ can the believer approach } \\
\text { God and worship Him; or, salvation is the } \\
\text { indispensable ingredient of crue worship }\end{array}$ & 123 & 1 & 1 \\
\hline 7 & $\begin{array}{l}\text { Worship to be true worship, must be in } \\
\text { harmony with the revelation God has } \\
\text { given (e.g., the Scriptures) }\end{array}$ & 122 & 0 & 3 \\
\hline 8 & $\begin{array}{l}\text { Worship "in spirit and truth" means to be } \\
\text { obedient to all God's commandments } \\
\text { including the Sabbath }\end{array}$ & 121 & 2 & 2 \\
\hline 9 & $\begin{array}{l}\text { Liturgy as appiied to so-called "liturgical" } \\
\text { churches is a very narrow application of } \\
\text { the real meaning of the word }\end{array}$ & 102 & 19 & 4 \\
\hline 10 & $\begin{array}{l}\text { Worship and mission are inseparable; } \\
\text { worship is the first mover of mission, } \\
\text { while mission is the natural outflow of } \\
\text { worship }\end{array}$ & 122 & 1 & 2 \\
\hline 11 & $\begin{array}{l}\text { Christian witness (mission) is in essence } \\
\text { the service (liturgy) by the Christian before } \\
\text { God in Christon behalf of mankind }\end{array}$ & 116 & 7 & 2 \\
\hline
\end{tabular}


TABLE 1--continued

\begin{tabular}{l|l|c|c|c}
\hline No. & Contents of the Statement & Yes & No & Unans. \\
\hline 12 & $\begin{array}{l}\text { The crisis sincere Christians will face in } \\
\text { the near future is about the issue of true } \\
\text { worship }\end{array}$ & 122 & 2 & 1 \\
13 & $\begin{array}{l}\text { Worship is not limited to time or place; } \\
\text { in all human activities the Christian can } \\
\text { worship God in Christ }\end{array}$ & 122 & 3 & 0 \\
a & $\begin{array}{l}\text { The seventh-day Sabbath is: } \\
\text { the weekly, returning climax of the } \\
\text { Christian's worship experience }\end{array}$ & 114 & 2 & 9 \\
the only day to worship God & $\begin{array}{l}\text { a day to worship God in spirit and truth } \\
\text { a day of blessing so that the sincere } \\
\text { worshiper of God can live a God- } \\
\text { pleasing worshipful life throughout the } \\
\text { week }\end{array}$ & 92 & 19 & 14 \\
\hline
\end{tabular}


13 were drawn from chapter III in which the timeliness and the spirituality of Christian worship were discussed (see the materials under the subtitle, "Worship and Pneumatology"). Chapter IV, entitled "Worship and Liturgy," was the source for statements 3,9 , and 11 . The awareness principle in Christian worship was discussed in chapter II of Part One. This essential principle was presented in statement 4 of the questionnaire. Statement 5 had its roots in that part of chapter III entitled, "Worship is God-initiated and God-centered." The soteriology and christology of worship functioned as the basis of statement 6 . The scriptural reasons for which Christian worship is qualified as true worship (see statements 7,8 , and 14) were discussed in the chapter, "Toward a Theology of Christian Worship" under the subtitle "Worship and Pneumatology, " and chapter V, "Worship and Sabbath: A Reciprocity."

The indissoluble link between Christian worship and the mission of the redeemed fellowship was the subject which was elaborated upon in the sections of chapter II eneitled "Worship and Ecclesiology" and "Worship and Mission." The additional chapter "Worship and Liturgy" was another approach to this important worship principle (statements 10 and 11). Statement 12 was based on a recapitulation of the series of sermons during the worship-emphasis week. The next to the last sermon dealt with the principles of Christian worship placed in their apocalyptic perspective. The sermon 
was preached on Friday evening. The A.S.W.A. students were called upon to make a decision and take their stand in the worship of God.

Table 2 shows the data collated from the responses the students gave to the statements on worship in this section of the questionnaire.

In the course of the twelve sermons the students were led from one principle of Christian worship to another until they were led to the subject of the climax of worship, namely, the Sabbath.

Since the information communicated to the students during this worshjp-emphasis week is represented by the theology of Christian worship presented in the first part of this project and by the twelve sermon outlines, of which examples are given in this part of the paper, it does not seem necessary to discuss each of these worship statements and the corresponding number of responses. It is assumed that some general observations which are the result of a subjective impression of what impact this worship series had on the students attending the meetings may suffice.

One observation which may be drawn from this information is that almost all the respondents remembered the points which had been discussed. Several items seemed to have been readily grasped. As far as the concept of liturgy was concerned (statements 3 and 11), most of the students had caught the larger meaning as explained in 
sermons 9 and 10,1 while only sever students seemed to have some difficulty with these ideas.

From the 125 respondents an average of more than 110 students responded correctly to these worship statements. Eight students, on the average, were not inclined to do so.

The statistics collated from this questionnaire may lead one to the conclusion that, because of this series of sermons, the principles of Christian worship were well received and understood by the majority of the A.S.W.A. students. Furthermore, the indication seems to be that a well-planned series of sermons with the purpose of communicating an important topic like Christian worship in order to upbuild or edify God's people (cf. Eph 4:12; Rev 14:7) in their worship, can be effective and successful.

\section{Written Testimonies}

The A.S.W.A. students were encouraged to write a personal reaction, in addition to the questionnaire, in which they expressed their particular experiences during the Week of Spiritual Emphasis. Out of the ninety-four positive questionnaire responses, fifty-four students (57.4 percent) responded to this request. ${ }^{2}$

Table 2. shows the characteristic phrases about Christian worship found in these written testimonies (column 2). The numbers

\footnotetext{
${ }^{1}$ See Part One, chapter IV.

2 See appendix $E$, section $\mathrm{I}: 7$.
} 
TABLE 2

TABULATICN OF WRITTEN TESTIMONIES

$\frac{\text { Characteristic Phrases }}{\text { A } \quad \begin{array}{l}\text { The week of spiritual emphasis: } \\ \text { a blessing; a privilege; unique }\end{array}}$

B Gained insight; broadened attitude and behavior toward worship; enlightening in Christian experience; enriching; strengthening faith

C Worship commits man in his totality; worship added dimension each moment of life

D Understanding of real meaning of liturgy; added more meaning and knowledge

E Peace of mind during the series; enabled to trust God more; special touch and impact on mind and heart; resentment was gone; poem; spiritual growth cannot be overemphasized

F Worship is also mission or service for God; to help others

G Many gospel words concerning worship; highly scholastic; systematic; full of sound theology; vast information

H Battle about worship; found my conscience and body inspired as to where I should find myself
Number of Testimonies

$2,12,13,22,26,27$ $28,30,31,37,38,43$, 48

$3,6,8,9,12,13,14$, $15,16,17,18,19,20$, $21,22,23,24,25,26$, $28,31,32,34,35,37$, $38,39.41,42,43,44$, $45,46,47,49,52,53$

$4,5,15,16,24,29,30$ $33,44,48,49,50$

$10,11,12,13,15,16$, $19,21,26,27,28,29$, $39,40,41,42,44,48$

$2,5,9,14,16,25,32$, $33,40,43,54$

$\mid$\begin{tabular}{l|l}
$3,10,16,23,28,29$, \\
$30,37,44,46,52$ & 11 \\
$7,13,14,16,28,32$, & 11 \\
$38,40,48,51$ & 11 \\
$3,11,25,38,46$ & 5
\end{tabular}


TABLE 2--continued

\begin{tabular}{l|l|c|c}
\hline & Characteristic Phrases & Number of Testimonies & Total \\
\hline 1 & \multicolumn{1}{c}{2} & 3 & 4 \\
\hline I & $\begin{array}{l}\text { Sermons presented personal } \\
\text { conviction; successful; effect- } \\
\text { ive sermons; everything suc- } \\
\text { cessful }\end{array}$ & $7,14,16,28,33,54$ & \\
J & $\begin{array}{l}\text { Week of spiritual emphasis } \\
\text { yielded dividends already; } \\
\text { since this week I have been } \\
\text { noticing a change; must follow } \\
\text { the rules; many repented and } \\
\text { are preparing for baptism; } \\
\text { decided to be baptized during }\end{array}$ & $\begin{array}{l}\mathbf{5 3}, \underline{54}, \underline{32}, \underline{36}, 49, \underline{51}, \\
\text { next baptism }\end{array}$ & 6 \\
\hline
\end{tabular}


of the testimonies in which the particular phrases were used are listed sequentially (column 3). From this systematic arrangement it becomes obvious that the contents of the testimonies can be divided roughly into two categories, (1) the intellectual; i.e., evidence of an improved understanding of worship and (2) the spiritual; i.e., indications that during this Week of Worship Emphasis students experienced spiritual growth.

Statements classified under the letters B, D, and G fall into category 1 , while statements under the letters A, C, E, F, H, I, and $J$ belong to category 2. There were sixty-six statements which seem to indicate increased understanding and sixty-five statements expressing certain spiritual growth.

From these testimonies it is clear that many students listened to the unfolding of the principles of Christian worship with interest. There is evidence that the A.S.W.A. students acquired additional information about Christian worship. Phrases like "gained insight," "enriching" (see under B), "understanding of the real meaning of liturgy," "added more meaning anu knowledge" (see under D), and "systematic" and "full of sound theology" (see under G) are indications of this. The systematic development and exposition of the principles of Christian worship as presented in Part One of this project and communicated to the A.S.W.A. students by means of this series of sermons seems to have been well received and understood. 
Some specific statements in some of the testimonies clearly reflect the particular worship principles which were presented to the students. The following illustrate this observation: the testimonial statement "worship commits man in his totality" (see table 2 , under C) may have roots in chapter II of Part One of the project, subsection "Some Non-Scriptural Definitions," and in chapter III, in those materials under the headings, "Worship: a God-man Interaction," "Worship and Soteriology," and "Worship and Mission." When students write that they understand "the real meaning of liturgy" (see table 2, under D), an obvious connection may be made with chapter IV of Part One of the project, entitled "Worship and Liturgy" and with some sections of chapter III, "Worship and Ecclesiology" and "Worship and Mission." Likewise the statement in one of these testimonies--"Worship is also mission or service of God"--could well be the intellectual result of comprehending the worship principles which were discussed in the section mentioned earlier.

\section{Attitudinal Changes}

Sections B, D, G, and, in a certain sense, section $J$ of Table 2 show that the student participants in the Week of Spiritual Emphasis acquired an increased knowledge about worship, liturgy, and mission in Christ. It is understood that, generally speaking, individuals do change their attitude to some degree when they are exposed to different feople, circumstances, ideas, and information. 
Having been exposed to and having participated in this week of worship emphasis, students gave indications in their written testimonies that a change of attitude had taken place in their lives. Expressions like "broadened my attitude" (number 3 ), "to bring to my knowledge the proper attitude toward worship" (number 6), and "reverential attitude" (number 28) give indications in this respect. There were also implicit statements indicating a degree of attitudinal change (numbers $2,9,15,17,19,21,24,25,36,38,40,51$, and 52). A few examples of these implicit or indirect indications are: "I was full of resentment but after the week I discovered that resentment is gone," (number 2); "I have been noticing a change and have been trying to play my part. . ." (number 9); "I have pledged to serve my Lord faithfully" (number 19); "I have made up my mind to worship God. . ." (number 24); "Now I realize. . ." (number 25); "This knowledge will help me in no small measure in readjusting my way of worship" (number 38); and "I felt I should devote of my life to God" (number 40).

\section{Baptism}

At the end of each semester a baptism is cheduled at A.S.W.A. It was during the second semester of the $1977 / 1978$ academic year that a baptism was conducted on Friday afternoon, April 3.4.

Several of the writien testimonies gave indication that 
there were students who had decided during and after the worshipemphasis week to be baptized. I The president of the school made the observation that some of the young people were baptized specifically as a result of the week. ${ }^{2}$ Five non-Adventist students made the decision in February, expressing their desire to be baptized during the forth-coming baptismal service, while another non-Adventist student was baptized later in $1979 .{ }^{3}$ Later during the school year, these six students wrote and submitted a statement explaining how they arrived at this important decision in their lives. These statements confirm the fact that it was the Week of Worship Emphasis which had helped them take this important step in their religious lives.

Three of the newly baptized students had held membership in the Anglican Church, one student had been a Muslim, one had belonged to the Methodist Church, and the sixth student, who was baptized later, had been a member of the Church of Christ.

\section{Conclusion}

The Week of Spiritual Emphasis accomplished that which it had been planned and prepared to do: (1) to give the A.S.W.A. students more theological information about $\mathrm{Christian}$ worship and enabie them to reassess their worship, and (2) to present that information in

\footnotetext{
Irable 2, Section J, 32, 36, 51, 53, 54 .

${ }^{2}$ See appendix $F$, last paragraph.

${ }^{3}$ See appendix $\mathrm{G}$.
} 
such a way that attitudes toward Christian worship might change and spiritual development be experienced by the students.

From the information discussed in this paper, the conclusion may be drawn that these purposes were fulfilled. 


\section{CHAPTER IX}

\section{CONCLUSION}

There is no greater challenge than to learn how to worship God, the Creator and Redeemer, "in spirit and truth"? The truth about Christian worship is hidden in the Scriptures like a pearl in a field (cf. Matt 13:46). God's people must make an effort to search for this truth as it is found in Christ (cf. John 5:39).

It does not simply require five, ten, or twelve years to learn what genuine worship of God is all about; rather, it takes the entire lifetime of a sincere Christian. For the Christian to live is for him to learn how to worship God. Learning is a dynamic process, as is worship. Worship is God-in-action and man-in-action as his response to God. Indeed, Christian worship is God-man interaction in Christ, inspired and guided by the Holy Spirit.

God's people do not know all the truth about that worship which comes from God and which leads men and women back to Him. This is why they must learn how to worship Him, who created and redeemed them through His only Son. One must not only endeavor to acquire more knowledge and gain increased understanding about the truth of worship but also to share in a greater worship experience. 
Since God is seriding forth a specific worship reformation message into the world ( 6 f. Rev $13 ; 14: 6-12$ ), how much more should His people, who function as the instruments of this gracious proclamation regarding divine worship endeavor to come to grips with the principles of Christian worship. This was the motivation for this project.

In this research project a position paper discussing the theological grounds and principles of Christian worship was prepared as a basis for a program for the deepening of understanding and experience in worship for the students of A.S. W. A.

Some means or methods of worship communication were briefly discussed in an attempt to encourage those who read this paper to implement programs of worship education in the local Seventh-day Adventist churches in West Africa. Implementation of one of the recommendations in the school was achieved through the presentation of twelve sermons to the school family in which sermons these principles of worship were shared. Although students do not always form the easiest group to which to present religious materials and that they are usually involved in heavy class work, worship education appears to have taken place during this particular week. This observation appears to be substantiated by the A.S.W.A. students' responses to the questionnaires they filled in after the Week of Worship Emphasis. These materials seemed to indicate that they had made an intelligent reassessment of Christian worship. There was evidénce that many of 
them seemed to share a deeper religious experience in Christian worship. Some non-Adventist students indicated that they had made additional religious commitments by expressing their desire to worship God according to the understanding they had acquired during that week; they desired to become members of the Seventh-day Adventist church through baptism.

Worship-emphasis weeks, worship seminars/workshops, worship Bible-study groups, worship prayer meetings, and other worship programs can be planned and prepared by the worship committee in any local church in West Africa. As a result, God's people may grow in grace and in sanctity so that their worship as a redeemed fellowship on the Sabbath may truly be "in spirit and truth." God's people will give God an appropriate response as a worshiping fellowship by dedicating themselves in service to Him. They will leave God's presence to enter into the world as a redeeming fellowship, worshiping Him by means of their liturgical life to the glory of God, the Father. 
APPENDICES 
APPENDIX A

A LETTER TO THE A.S.W.A. RELIGION DEPARTMENT

August 4, 1977 


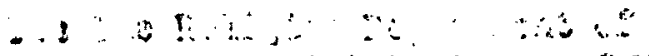

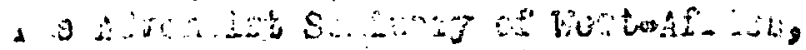

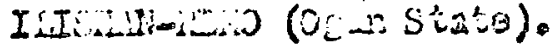

$$
44020_{8} 37 \%
$$

\section{Leso Escieren,}

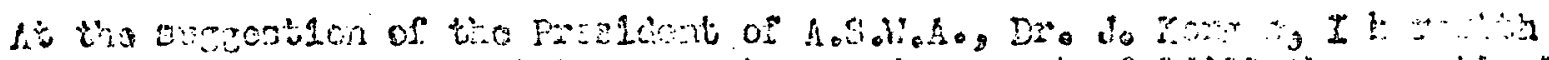

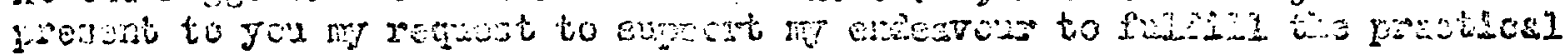

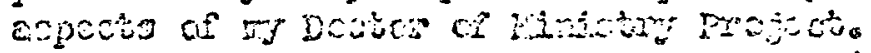

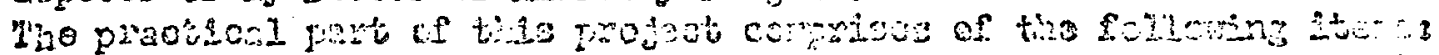

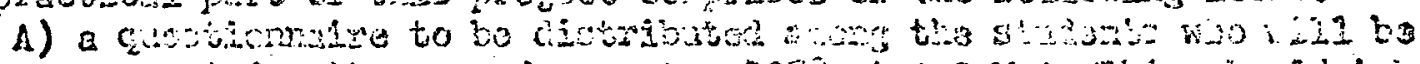

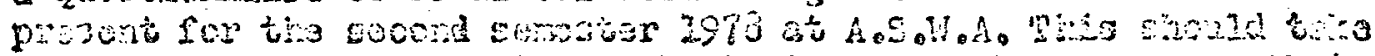
P.

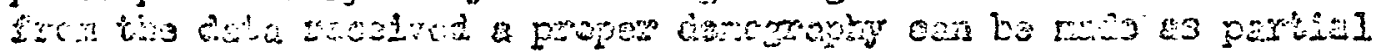

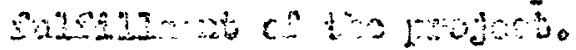

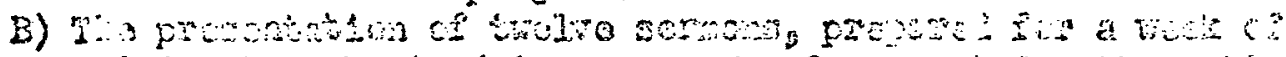

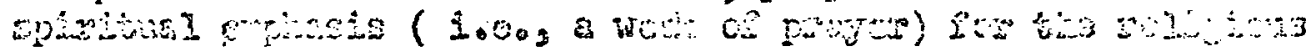

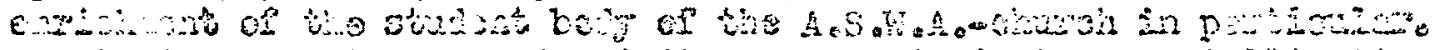

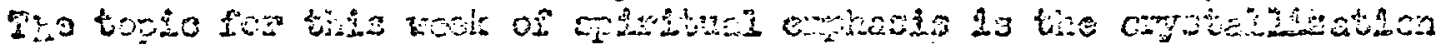

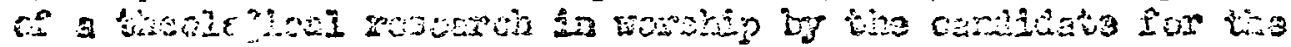

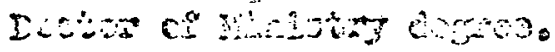

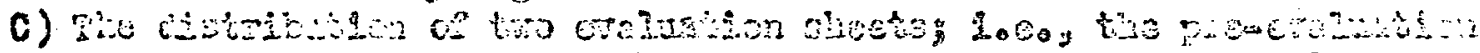

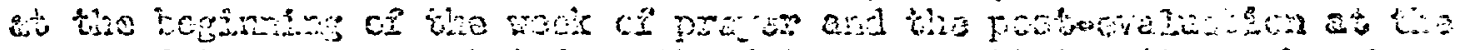

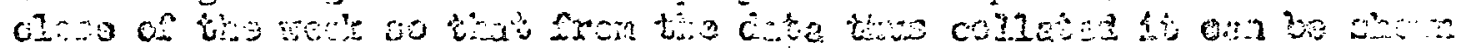
wewer 120 l?

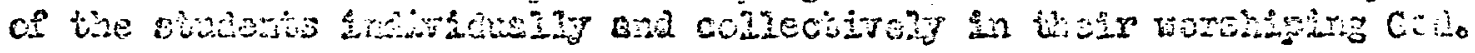

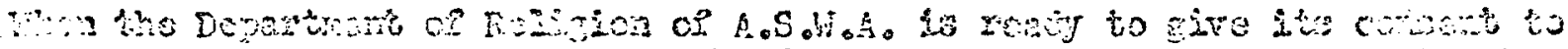

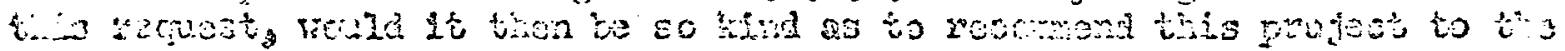

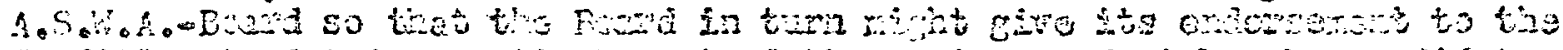

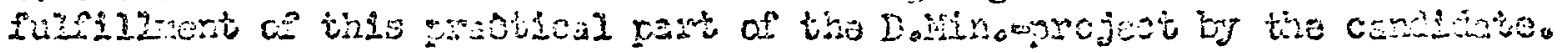

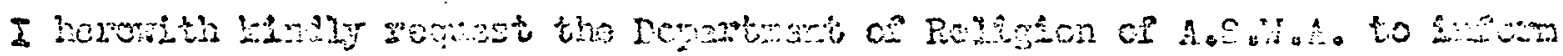

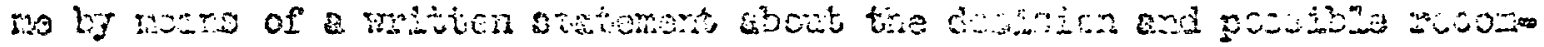

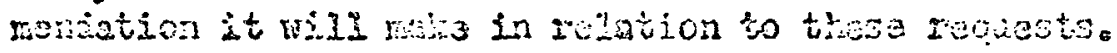

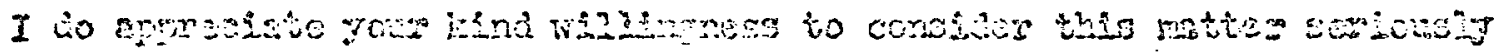

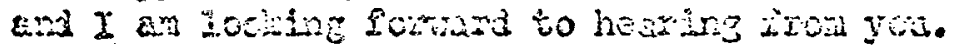

Hod aind chostion greobingo,

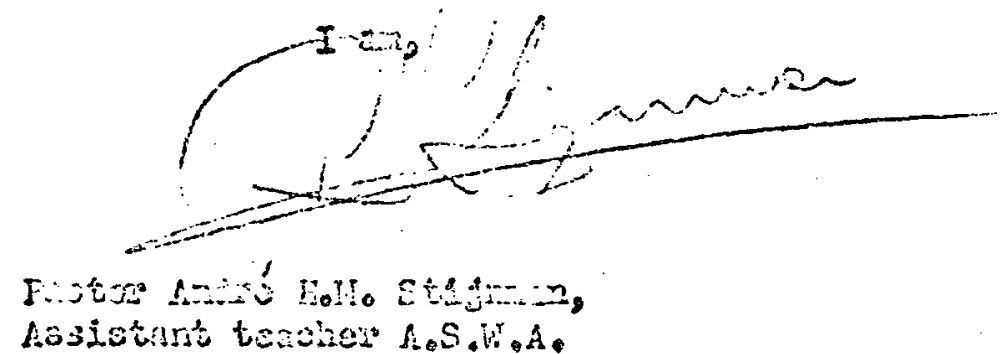


APPENDIX B

THE RESPONSE OF THE A.S. W.A. EXECUTIVE BOARD

October 6, 1977 


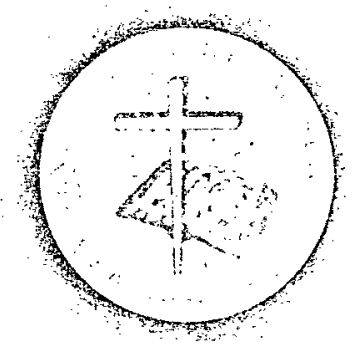

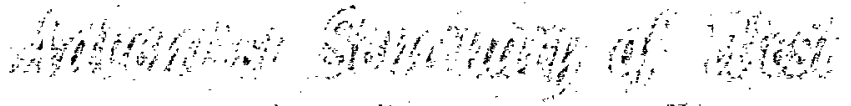

$$
\begin{aligned}
& \text { thit? }
\end{aligned}
$$

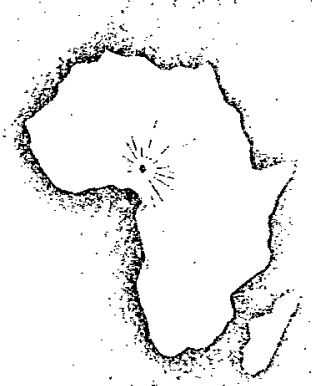

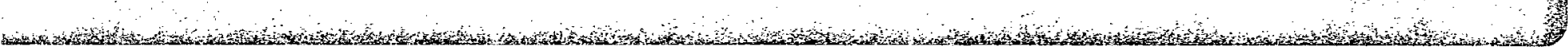

6th October, 1977

Pastor A. Stijnman,

A. S. Wo Ao,

Ilishan Reno. $^{2}$

Dear Pastor Stijrman,

The ASWA Execlitive Board met this moming and voted for you to conduct the Heek of Prayer February 11-18. May the Lord bless you in this important undertaking.

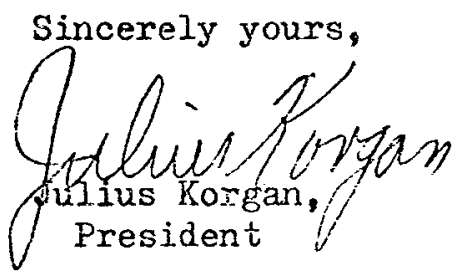

$\mathrm{JK} / \mathrm{po}$. 


\section{APPENDIX C}

THE A.S.W.A. WEEK OF SPIRITUAL EMPHASIS PROGRAM

February 12-18, 1978 


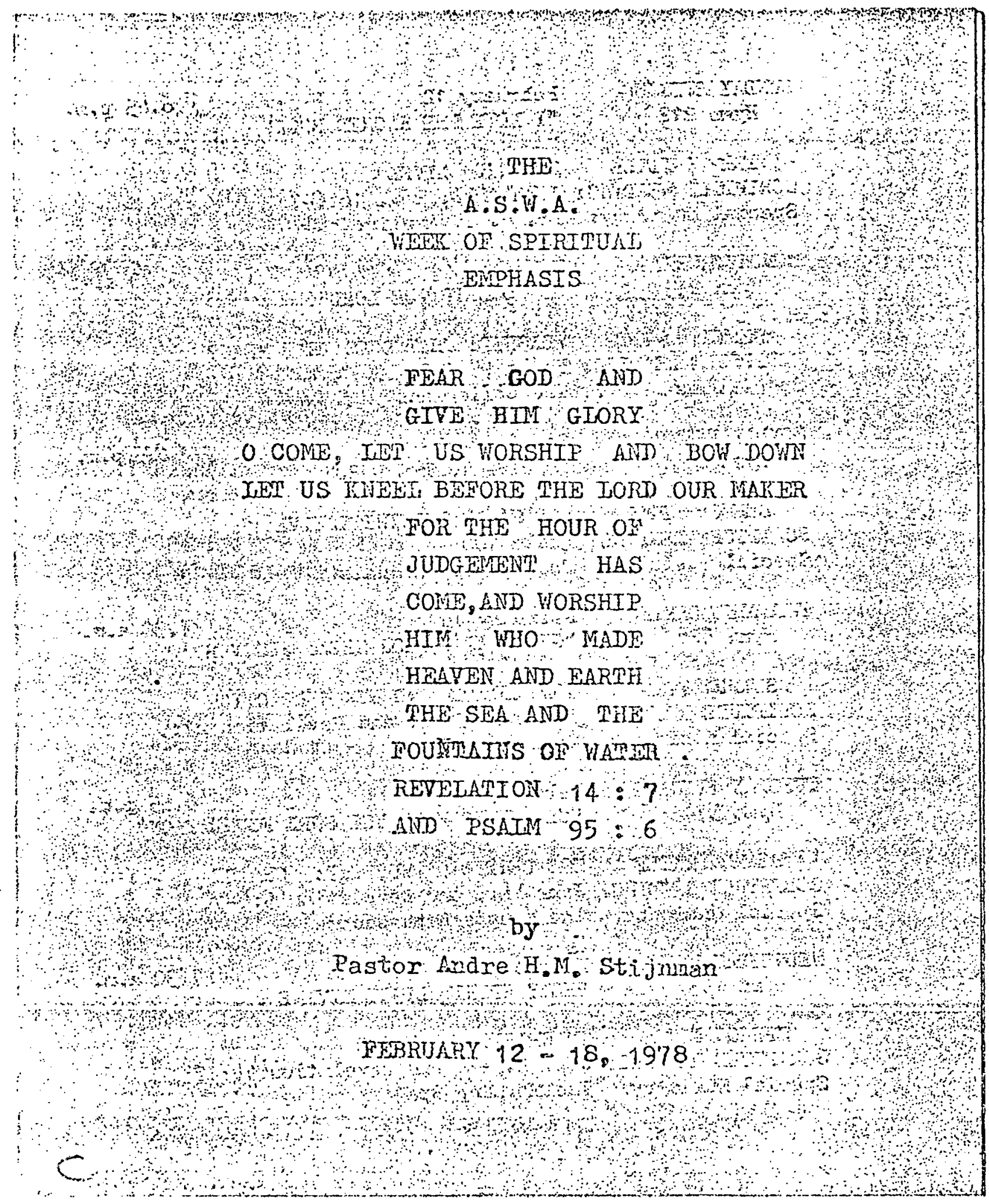




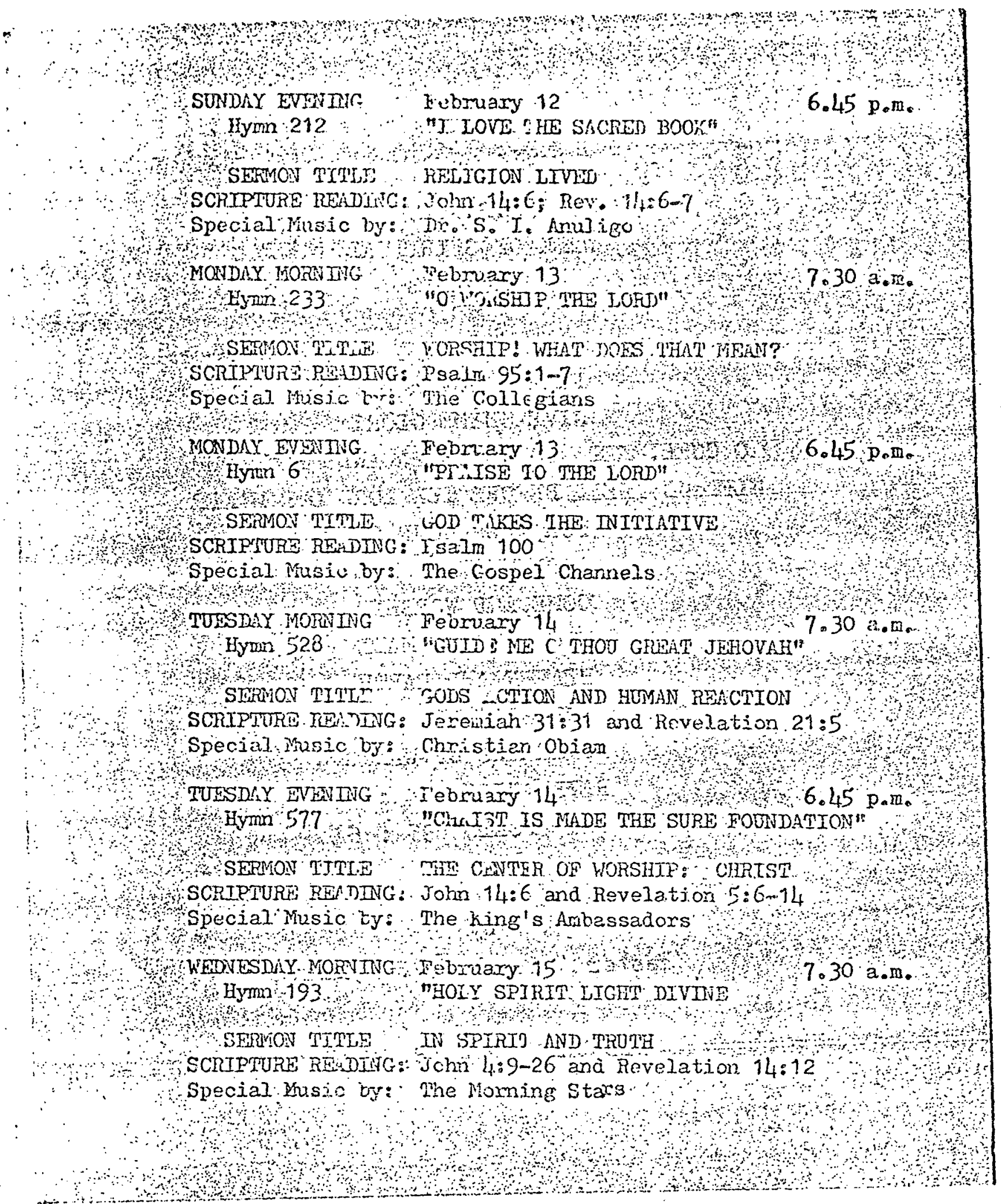




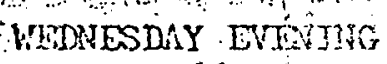

$17 y m$ 66

SSERMOI TITIS

SCRIPIVRE READING:

special Yusic tgr:

THORSDAY MORUING:

Hymin 263

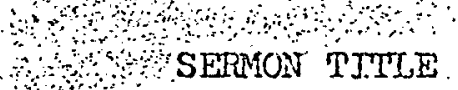

SCRIPTURE RERDING:

Special Music by:

THURSDHY EVENING

Hyma 135

SERMON TITLS SCRIPTURE PRADING:

Special Music by:

FRIDAY MOENTIE

ilymin 700 s.

SEPMON TITLE

SCRIPTURE RBADTNG:

Special Music by:

FRTDAY IBVDNING

Hym 507

pins

II SERMON TITLE

SCRTINURE READING:

Specjal Music by:

SABBATH

Hym 4

SERPON TITLE

SCRTPTURE REHDTIG:

Special ifusic by:

Hyma 309
Febriary 15

6.45

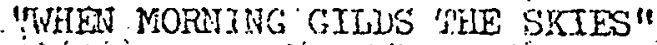

SHLVATION ALYS WOASHIP

Eohesians 2:8-10

iniss Oribo

February 16

"THE CHURCH'S ONE JOUNDH'ION"

CHURCH AND YISSION: WHERE WORSHIP?

Matthew 5:14-16 and Revelation 10:11

The Stijnman's Family

Febriatry 16

"ARISE MY SOUL, ARTSE"

\section{$6.45 \mathrm{p} . \mathrm{m}$.}

IIPTRGICLI CHRISTUANS: XRS OR NO?

Eebrews $4: 14-16 ; 8: 1-2$

Dr. J. Korgari

February 17

"WHEN WE WALK WTTY TTHS LORD"

HEAVENLIT SEOJENC.

II Corinthians 5:17-20, Rev. 1:5-6

Ladies of White Yall

rebruary 17

"WAO IS ON THE LORD'S SIDE"

TYS BATTLE ABOUT WORSHTP

Revelation $14: 9-12 ; 12-17$

The Seminary Choins

February $18 \quad 8: 15$ a. La \& 11.00

"THE GOD OT ABMLHSM PRNTSE"

$6.45 \mathrm{p} . \mathrm{m}$.

CLIUX OF WORSIIP: SABBATI

Bzekiel 20:12, 20 and Mark: 2:27-28

His. Is, Clemonds

"I,OR OF THE SALBST"

का 


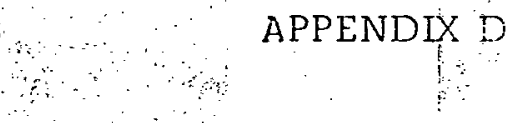

REMAINING SERMON OUTLINES

WEEK OF WORSHIP EMPHASIS

A.S. W.A., February 12-i8, 1978 
Sermon Outline 2: Worship: What Does That Mean? Scripture Reading: Ps 95:1-7

I. a. A dictionary definition of worship: "Reverence for worth, honor, high respect paid anyone . . . that deserves it."

b. The Bible: "Bow down to earth." Gen 18:12; 24:52; Ps $95: 6$

II. a. 1. The Hebrew word presupposes mental disposition; inner attitude; reverence and service. Example: Abram

2. The Greek word: to prostrate oneself before a person and kiss the feet or the hem of a garment, the ground

3. In the N.T. the object is always someone divine. Examples: Matt 8:9; 9:21; Acts 10:26; Rev 22:9

b. 1. At least two persons are involved in worship. One who bows down and the one before whom the bowing is done. Abram and the Lord; individuals before Christ. We before God

2. Christian worship presupposes a relationship, namely between the Redeemer and the redeemed (e.g., John 14:6)

3. K. Barth, "Worship is the most important, the most momentous, and most majestic thing which can possibly take place on earth."

c. Five essential elements in worship

1. Awareness of God. The present situation: God here and now

2. The response of this awareness of God. If there is no awareness, no worship can take place

3. Humility. The almighty God, Creator, and the frail sinner-man. Example: Isa 6. Therefore: reverence, honor, devotion, adoration, praise. Humbleness

4. It is the expression of the redeamed individual. God is the almighty Creator and also the loving Redeemer. True worship is "God reseen and man remade." Ministry 31:56

5. It is the expression that God is reigning in the person's life. It is the devotion of the heart to this GodSaviour. Matt 12:28; Rom 14:17; Gal 2:20

III. a. Do you want to devote your heart and yourself to God?

b. Do you wish to experience God's love in your life?

c. Do you like to search the Scriptures to receive more light on this most important, most momentous thing which can pos sibly take place on earth? John 5:39; Ps 95:6

d. I'd like to know more about worship; what about you? 
Sermon Outline 3: God Takes the Initiative Scripture Reading: Ps 100

I. Whether a person's worship is true worship remains unanswered as long as the tests of the Scriptures are not applied. The Scriptures help us to detect false worship while discovering true worship. John 5:39; 17:17

II. a. 1. From Gen 1:1 to Rev 22:21 God is revealed as Creator and Recreator. Statements which tell us that God is the Creator: Exod 20:8-11; John 1:1-3; Rev 14:6-7. Basic reason to worship God is: He is our Creator; not our equal

2. This motive is in harmony with the motive of the heavenly creatures who worship God. Rev 4:9-11, especially llb. We know that God is Creator of all: through nature (Ps 19), through the Scriptures (2 Tim 3:16), through Christ (Heb 1:1-2). In worship God is recognized as such

3. God's people are privileged to understand more fully the mighty creatorship of God; thus share a deeper worship experience. Rev 14:7. Examples: (1) Gospel Workers, p. 178, "True reverence for God is inspired ..." (2) The testimony of Grady Davis. (3) Is the living Creator also your God?.

b. God is the initiator of worship

1. It is God who wills that worship is done

2. It is God who calls into worship and creates within man the desire to worship Him

3. The worship direction is not: from man to God, but the opposite: from God to man

c. The outstanding example of this is found in Isa 6:1-9

1. Usually referred to as isaiah's adoration, confession, affirmation, dedication, and service

2. However, basic and most important is: God's very first action in this worship act of the prophet

3. Without God's initiative Isaiah could never have expressed adoration, confession, dedication, and service

III. a. Remember what was discovered: in worship a relationship is established, i.e., the God-man relationship. Here we discover that God takes the initiative in creating this Godman relationship

b. Before man can express anything, he first must have been impressed with what God has done, is doing, and shall do. 
c. God makes man aware that He is, that He is Creator, and that He is also his Saviour

d. Thus in worship God always comes first BEFORE man can give Him a worshipful response. (1) Moses' experience (Exod 2 and 3); (2) Isaiah's experience (Isa 6); (3) that was Daniel's experience (Dan 9); it is the experience of God's people (Rev 14:6-7)

9T: 156. The religion which comes from God (initiative) is the only religion which will lead to Him (true worship) Is this also your experience? How do you relate to this great God? 
Sermon Outline 5: The Center of Worship, Christ Scripture Reading: Rev 5:6-14; John 14:6

I. In Judaism the Almighty, Adonai, is worshipped; in Islam Allah is worshipped; in Buddhism, Buddha; in Hinauism, many gods and goddesses. But in Christianity the only true God is worshipped in and through Jesus Christ, the Lord of the church God is at work in the realization of His plan of salvation! Did men ever see God? Yes? No? John 1:18; 1 Tim 6:16 God revealed himself to men in and through Jesus, the Christ

a. YHWH - LORD is the preincarnate Son of God. John 10: 11, 14. Christ is saying, "I am David's shepherd; I am his LORD." Ps 23:1; cf. John 8:58

b. God created through the Word. John 1:1-3; Ps 33:6, 9

c. God is recreating the world in and through Christ. John $3: 16 ; 2$ Cor $5: 17-19$

II. a. Like God was in Christ in OT so is God in Christ in NT. The living God is not like a lifeless idol. An idol is idle all right! But our God is a living God and $\mathrm{He}$ was and is in Christ Jesus. Col 2:9; John 14:31; 5:17, 30

"The heart of the action is God's deed in the person of His Son Jesus, the Christ." (Lutheran theologian)

b. Whatever the Son of God did, does, and shall do it is God who did, does, and shall do all this in Christ for us. God at work in Christ! God alive! God at work!

c. Therefore: worship can be done only in and through Christ. Man's decent response, his reaction, his worship is in and through Christ alone

d. Christian worship has Jesus Christ as its center. Matt 28: 20. Notice verse 17 (PROSKYNESIS). They worshipped the resurrected Jesus

e. When God speaks in Christ then that which is spoken is taking place. This is understood by faith alone. Gen I. When He says Matt 18:20 (Matt 28:20)---do we believe? Worshipping God then is the redeemed man's response to Him in Christ

It is: God in Christ; by His grace it is: man in Christ It is: God-Christ-man; and man-Christ-God. That is the only way. Jesus Christ is the center Think also of John 10:9; John 15:5; Phil 4:13

III. a. Without Christ your worship is not biblicai worship

b. Without Him your worship is not in harmony with the Word

c. Without Jesus your worship is what it is indeed: YOUR worship. Therefore, vanity; yes, idolatry 
d. A noted scholar writes, "All true worship is Christocentric, for only in Christ can God be found." (Segler)

Have you found God? Find Him in Christ

Then having accepted Him by faith, you have been placed in the position to worship Him 
Sermon Outline 6: In Spirit and Truth

Scripture Reading: John 4:19-26

I. There is an intimate link between worship and the Spirit

a. Task of the Holy Spirit, John 16:8

b. Rebirth by the Holy Spirit, John 3:3-6

c. Christ's continual presence in the Holy Spirit, John 16:7-15

d. The condition: Rom 8:9, ". . . if he really dwells in you"

II. It is by the Holy Spirit that God's people worship Him

a. Through the H. Spirit God in Christ is in action during and gives guidance in worship. 2 Cor $3: 18$. The H. Spirit is indispensable in the worship of God. God's people are wholly dependent upon the H. Spirit to let their response to God become a decent response to Him, thus worship. Rom 8

b. Christ is present by the H. Spirit in His church Matt 28:20; Gal 2:20. The H. Spirit is "always God-at-hand ... is always God-at-work."

Prophets and Kings, pp. 49-50, God "meets His people by the Spirit."

c. The H. Spirit directs God's people into true worship Gen 1:2; John 16:8; Rom 1:16. God's Spirit moves upon God's own people. He is the divine agent helping the Christian in the way of sanctification, changing him from one degree of glory into another. Thus his worship improves qualitatively

III. John $4: 23$; "in spirit and truth"

a. The issue: worship in Samaria or in Jerusalem? But for Christ this is not the real issue at all. True worship is not limited to a temple or church building

b. The phrase is Christ's definition of genuine worship

1. Christ explains the nature of worship; that is:

i. inspired by the $\mathrm{H}$. Spirit; come from the heart controlled by the Spirit

ii. it must be done in harmony with the revelation of God; John 14:6

2. You like to become a worshiper of God "in spirit"? Then let your response be inspired and guided by the H. Spirit. Approach the throne of God boldly in the name of Christ. Undividedly, unreservedly, completely, wholly

3. You like to become a worshiper of God "in truth"? Then let your worship be in harmony with the truth as it is in Christ. That is also, obedience to God's 
revelation in Christ, His Son. It is the $H$. Spirit who strengthens the worshiper to do just that, John 16:13

4. Rom 8:9, 15-17, 26

Desire of Ages, p. 189: "Not by seeking a holy mountain..."

Prophets and Kings, p. 50: "Unless they worship Him in spirit and truth in the beauty of holiness, their coming together will be of no avail."

Worship Him, in spirit and truth 
Sermon Outline 8: Church and Mission: Where Worship?

Scripture Reading: Matt 5:14-16; I Pet 2:9-10

I. Church: persons who by grace have been saved through faith (Eph 2:8)

a. The saved must first meet God before being sent

b. The church has no right or authority to go into the world unless it has received the message from the Lord

II. Worship and the church

a. First and foremost the church exists for God; the first duty of the church is worship. Acts $1: 4-9$

b. When the church worships, twofold identification happens. 1. the church realizes anew that it is God's people

2. the world recognizes that the church is "a peculiar people"

c. The redeemed, the church, are called children of God:

1. Christ is the eldest brother; God, the Father. Heb 2:11

2. Fellowship; the family of God (koinonia) I John 1:3-7

III. Worship and mission

a. God is the sending God. Angels, prophets, Christ sent His disciples. He now sends the church Matt 11:28 comes first, followed by Matt 28:18-20

1. God calls His people together to worship

2. During their worship God sends the Church into the world

b. Church is a redeemed fellowship and a redeeming one To be church and to be missionary are the same thing Worship is the God-initiated means that keeps church and mission in a healthy balance!

c. We enter into the worship of God to be enabled to depart for service. Illustr.: Moses; Isaiah; the apostles

IV. The biblical sequence: worship and mission; not mission and worship

Because: where there is no worship there is no commission! If no vision, where is the mission?

"It is from the life of worship. . . that the Church spreads itself abroad into the world to mingle with it . . ." von Allmen

a. Thus, mission is the healthy outflow of worship in spirit and truth. Man cannot worship God in spirit and truth if he worships Him "empty-handed." Unfaithful steward (Matt 25:14f) 
b. We leave the worship so as to do God's will there where we work; where we study; where we relax; where we walk and talk

c. Throughout the week. From thence we return on the seventh day to worship Him who has been gracious unto us

d. We praise, bow down, honor, confess, and glorify Him, our Creator and Redeemer. How meaningful worship is!!!

e. What the heart is to the body, worship is to the church. Worship is the heart beat of the church's mission Worship Him, the God who redeems and the God who sends Are you aware that God is calling you? If so, are you aware also that God is sending you? If so, do you dare to enter into His holy presence empty-handed? 
Sermon Outline 9: Liturgical Christians: Yes or No?

Scripture Reading: Heb. $4: 14-16 ; \underline{8}: 1-2$

I. Generally speaking, there is a rather negative attitude towards liturgy. Reasons: no knowledge; misunderstanding; identification of the word with Roman Catholicism

II. a. Meaning of the word liturgy

1. A secular word originally; LEITOS-ERGON = people-work Illustrate: the ancient Greeks in Athens

2. Became an ecclesiastical word; a cultic term LXX translators chose LEITOURGIA for the Hebrew SHERETH

3. The word was thus applied to just a cultic group of individuals; i.e., the priests

4. In the early Christian church: used again in its original meaning; all Christians doing service. 1 Pet 2:9; Rev $1: 6$

5. Acts 13:1-3; translated with worship!

"The liturgy of the Christian Church is a religious service offered by the public to the Lord." R. Paquier, p. 49

b. Relationship between liturgy and Christ.

1. Heb 8:1-2; Christ, the minister of God's people (Liturgist)

2. Heb 9:21f; Christ's liturgy is superior

3. Heb 9. Moses, the liturgist of the people of Israel; likewise, Jesus Christ, the Liturgist for all God's people

c. Christ's service, ministry as the Lamb of God and His liturgy as the High priest in heaven is our liturgy, too.

III. The relationship between worship and liturgy

a. Heb 1:1-4; Gal 1:3; 6:8. Synagogue language!

b. Worship creates liturgy; the way in which worship is done. ". . . it is impossible to conduct a (worship) service without liturgy." Pease, p. 51

Thus: church-worship-liturgy are interrelated, interdependent

c. How to do liturgy in worship?

1. "Liturgy is a natural action in the presence of God"

2. Liturgy is the work or service of God's people before Him (This we'll discuss tomorrow) In worship: the actual service of all faithful Christians gathered together in Christ as a fellowship. serving Fim 
3. Apply:

i. To enter the place of worship, the church

ii. How to enter into God's holy presence

iii. Participation in hymn singing and in prayer

iv. Bowing down on the knees and do confession (heart)

v. Paying attention to the reading of the Word

vi. Are you listening attentively to the sermon vii. To partake of the bread and of the wine; how?

In short: how do you react to God's love-act in worship?

d. All people praising, praying, hearing, affirming, offering, as members of one another, are answering God's call to the church to worship Him

e. Rev 1:6 and 1 Pet 2:9-10. You like to become a co-liturgist of Christ. He, your Liturgist in heaven; you His liturgist on earth in behalf of the people round about you. Wouldn't you join in serving God and mankind?

Yes, Lord, I am your servant; your liturgist, priest! 
Sermon Outline 11: The Battle About Worship

Scripture Reading: Rev 14:9-12;12:17

I. The first batte in the world, resulting in the shedding of innocent blood (Abel's) was about worship; the last is about worship Gen 4 to Rev 16:13-14 depict conflict between true and false worship. The crucial issue in Daniel and Revelation: the final controversy between true and false worship

Are you worshiping the God of Daniel; the God of John?

II. Worship in the books of Daniel and the Revelation

a. Daniel

1. First half is personal experience; second half, prophecy

2. Both parts have one thing in common: worship/liturgical life

3. True worshipers are victorious; idolators suffer defeat

i. Dan 1:20; faithfulness and integrity are blessed by God

ii. Dan 2; idolators unable to tell and interpret a dream

iii. Dan 3; deliverance of 3 faithful worshipers/servants

iv. Dan 4; self worship leads to self destruction

v. Dan 5; false worship/sacrilege; death and destruction

vi. Dan 6; the liturgical, worshipful Daniel delivered

4. Part two of the book reveals the history of true vorship versus false worship in prophetic perspective

i. Dan 7:21, 24-27; the power against God

ii. Dan 8; sanctuary and God's people trampled underfoot

iii. Dan 11; God's faithful people will be delivered

iv. Dan 12; Michael stands up to deliver His people

God's servants (liturgists) come forth victoriously!

5. YOU

When oppression, captivity, famine, unclean food, etc., where do you stand? You maintain that liturgical life? Deliverance like Dan 3 and 6 is waiting for you IF . . . If one remains faithful to God whatever the circumstances

What a victory in Christ! It is all yours . . . IF!

b. Revelation

1. The Roman Empire; is sue is worship

2. Caesar worship; required of all citizens; also Christians

3. Roman Empire: the type of mystical Roman Empire

4. Faithful Christians persecuted; even put to death! They refused to say "Caesar is Lord." Christ is LORD!

5. Domitian deified; people saluted, "Hail Lord and God!" 
6. All Roman citizens were his servants; had to worship him

7. The prophetic picture: Rev 13; 14:9-11, 17

Ancient Caesar worship reflected and intensified in mystical Roman Empire; climaxing in: battle about worship. Rev 13:15-17!

8. God's servants (liturgists), worshipers, encouraged to remain faithful by examples of worship "in spirit and truth"

i. Rev 4:1-11; heavenly worship, liturgical life

ii. Rev 7:9-12; worship by the REDEEMED and angels

iii. Rev 7:13-17; experience of God's faithful worshipers

III. Whom are YOU going to worship NOW and TOMORROW?

1. God, through Jesus Christ, the Lord? Is He your Lord also?

2. The man of lawlessness; anti-god? Are you his slave?

3. Is it: worshiping the Lamb or serving the beast?

4. Perseverance in loyalty to the Lord of the church or slavishly worshiping the beast or his image?

5. Worshiping the Creator and Redeemer, including on the seventh-day Sabbath and faithfully serving Him in the week

Or: to be dominated by anti-christ and worship that system, including the first day of the week?

6. This will be the pressure, the tribulation

7. This battle has to be fought first of all WITHIN you here and now. You have to decide; God is not forcing anybody

8. At whose side are you? To whom are you paying loyalty? To whom are you rendering service? Whom do you honor, revere, love, worship? Whose priests are you? Whose liturgists?

IV. ALTAR CALL

Rev 14:7-11; Rev 18:4; Rev 14:12

and worship Him 
Sermon Outline 12: Climax of Worship: Sabbath Scripture Reading Ezek 20:12, 20, Mork 2:27-28

I. In six days God created the heavens and the earth; Gen 1:31 Gen 2:1-3; the seventh day: God rested

a. Rested; not inactivity or fatigue, but joy, happiness, gladness because of Creation complete

b. Rested; another divine activity; upholding Creation

II. God's blessing. Not on light, waters, grass, trees But on creatures in the waters, in the air, on dry land God did not hallow these creatures; neither hallow Man!

a. Gen 2"3; He blessed the seventh day and made it holy. Nothing material was blessed with holiness. Immaterial thing!

It is: holiness in time

b. Gen 2:3; also "set apart for a particular purpose" Mark 2:27; "for man." Adam, Eve, Abel, Noah, Israel, YOU

c. God could hallow because He himself is holy. God is light, He creates light. God is life, He creates life... God is holy, He hallows. He makes holy for. . . man! . . . and man

d. For worship purposes

1. Seventh day was Adam's/Eve's first full day of life

2. Enjoying that day, Adam and Eve partook in holiness of God

3. Notwithstanding sin, Sabbath holiness remains

4. Exod 20:8-11; a relational commandment: God--man REMEMBER

i. God is a God of remembrance, Exod 2:23-24 because

ii. He is the Saviour, Exod 20:1,2

iii. He makes His people holy, Lev 19:2

Redemption comes first; sanctification follows, Exod 31:14

R. Hayim, "We have seen with our own eyes the tremencious change that the holiness of the Sabbath brings about ..."

5. Sabbath reminds of Re-creation, 2 Cor 5:17-21; Heb $4: 9$

God continues Salvation work within man on Sabbath; i.e., sanctification! Therefore: REMEMBER the Sabbath $4 \mathrm{~T}$, p. 249: ". . improvement of his spiritual condition" 
e. Sabbath is also the climax of the Christian's life

1. Sabbath is needed to maintain a worshipful life (liturg.)

2. The redeemed come together to worship; then they are sent back into the world as a redeeming people (mission/luturg.)

3. Sabbath worship: God's people are sanctified; Ezek 20:12, 20

4. Having fulfilled a six days worshipful life, God's children answer the invitation, "Remember the Sabbath day to keep it holy." "Come unto Me . . . and I will give you rest." (Matt 11:28) O Sabbath, climax of Heaverily rest!

5. Sabbath is not an interlude, but the climax of living Thus Sabbath is the inspirer, the other six days the inspired

III. What YOU and I are depends ALSO what the Sabbath is to US

a. 5T, p. 339; "A religion which is confined to Sabbath worship emits no rays of light to others"

b. To the degree YOU and I live a worshipful, liturgical, serving life during the week, to that degree can YOU and I worship God on the seventh day, the Sabbath E. G. White, "Man himself must be holy to keep the Sabbath holy"

c. 2 Cor 3:18; from Sabbath to Sabbath, till Christ returns O Sabbath; O climax of worship; O blessed rest. . . 


\section{APPENDIX E}

A QUESTIONNAIRE DISTRIBUTED ON FEBRUARY 19, 1978 
YOUR NANE:

February 19,1978

I 1. Were you present in all the meetings this week.

2. How many times did you attend (give the number)

3. How rilany times were you not able to attend $(, 9)$

4. What $\operatorname{day}(\mathrm{s})$ were you not present.

5. Did this week of spiritual enphasis add to your understanding of worship.

6. Did you make notes of the presentations on worship

7. Would you be willing to write a one paragraph personal reaction what this week has meant to you.

8. May I expect your reaction this week from you.

9. Are you going to worship God in harmony with what you have learned this week.

II 1. Any person can worship God as he thinks is most suitable to God.

2. Worship done in a churchbuilding is just a part of the individual's worshipful life.

3. Worship and liturgy are, in esserce, identical.

4. One can worship God only when he has become aware of the existence and the presence of God.

5. Worship presupposes that God aIways takes the initiative, and not the believer.

6. Only in Christ can the believer approach God and worship Him; or, salvation is the indispensable in. gredient of true worship.

7. Worship, to be true worship, must be in hamony with the revelation God has given (e.E., Scriptures).

8. Worship "in spirit and tmuth" means to be obedient to all God's commandmerts, including the Sabbath.

9. Iiturgy as applied to so-called "liturgical" churches is a very narrow application of the real meaning of the word.

10. Worship and mission are inseparable; worship is the first nover of mission, while mission is the natural outflow of worship.

11. Christian witness (mission) is in essence the service (Iiturgy) by the christian before God in Christ on behalf of mankind.

12. The crisis sincere christians will face in the near future is about the issue of true worship.

13. Worship is not Iimited to time or place: in all human activities the christian can worship God in Christ.

14. The seventh day Sabbath a) is the weelly, returning clinax of the christian's worship experience.

b) is the only day to worship God

c) is a day to worsinip God in spirit and truth. d) is a day of blessing so that the sincere worw shiper of God can Ijve the God pleasirg worshipful 2 ife in Christ throughout the weds.

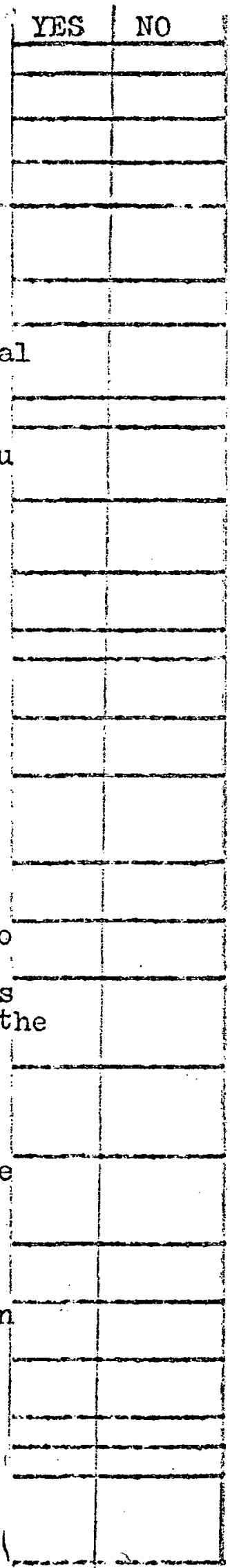




\section{APPENDIX F}

AN EVALUATION OF THE WEEK OF SPIRITUAL EMPHASIS

BY THE PRINCIPAL OF A.S. W. A. 
WVLUATION OF THE

WEEK OF

SPIRITUAL EMPHASIS

AT A.S.H.A.

February 12-18, 1978

Pastor Andre Stijnman, who is a member of the religion and theology faculty at the Adventist Seminary of lest frrica, was invited to conduct the Heek of Spiritual Emphasis on the ASWA campus at the above date. It was understood that this assignment was to be a part of his special project for the Doctor of Ministry degree at Andrews University。

I ain certain that Pastor Stijnman will submit a copy of his sermon titles so I shall not attempt to list theñ again. The serles had as its central theme the idea of woxship. The series was very carefully planned and presented. This is a characteristic of Pastor Stsjuman. He lets the Spirit wove him in his study, and he does not wali to be given words to say aftex he gets to the pulpit.

The series began with personal religion and worship. It proceded through Christ as the center of worship to the climax of whrship-whe Sabbath. Each sexmon was deeply spiritual and seemed to be well received by the audience.

Student audiences are not the easlest group to present relisious material to and especialiy so when it is in addition to class work. The evening meetings are a fairly good gauge of people's interest. llany people came from the community.

Ore may spak of sound theology, logical presentations, and Intoresting presentations. Pastor Stjjnman wade uso of all these, but the real proof of the success of preaching is the transformation of the lives of people. As the result of his reek of spixitual emphasis, sono of tho yourg people vero baptizec. Tharefore wo feel that the aeries of mestings was a success. 


\section{APPENDIX G}

REQUESTS FOR BAPTISM BY

NON-ADVENTIST A.S.W.A. STUDENTS

AFTER THE WORSHIP EMPHASIS WEEK 
The 1978 spiritual emphasis has influenced me in taking a decision to be baptized in April, 1978. It has also influenced my spiritual growth after my haptism.

(Signed) Muka (Muslim)

May I take this opportunity to state here that it was as a result of the week long spiritual emphasis held on ASWA campus between February 11 and 18, 1978, that influenced my decision to accept the Lord Jesus Christ as my personal Saviour, and eventually got baptized into the Seventh-day Adventist Church.

(Signed) Chidinma (Methodist)

My getting baptized in the Adventist Church is that of conversion and nothing else. . . .

After the week of spiritual emphasis, I thought over in my mind all that he had said and my mind accepted all and I got converted and decided to be baptized as a member of the Seventh-day Adventist Church. I pray that I will be firm in the church.

(Signed) Chidinma (Anglican)

I was born Protestant. I was personally converted in 1976 by the attitude of the Adventists in my environment. However, I did not receive baptism till April, 1978, after Pastor A. Stijnman's series of sermons on 'Norship during the week of spiritual emphasis. . . His sermons clarified certain doubts in me. . . With these new ideas in me, coupled with my previous knowledge of Adventist doctrine . . I I decided to be baptized.

(Signed) Emmanuel (Anglican)

During the week of spiritual emphasis it was Pastor Stijnman who preached. . . .

His preaching led to the conversion of many souls, of which I was one. The way and the manner he presented his sermons made mie to see my weak points and I became ashamed 
of myself. After some days of his sermons, I enrolled in the baptismal class. . .

Pastor Stijnman baptized me. Now, I am very happy for being one of the SDA members today.

(Signed) Chinazaekpere

(Anglican)

It was in 1979 that another student was baptized as a result of the messages on Christian worship presented in 1978. This student wrote,

Sincerely speaking, I was baptized later in 1979 because of the series of sermons he preached during that week. . . . I must not fail to mention the fact that his personal Christian life on the campus contributed to my conversion.

(Signed) Bernard

(Church of Christ) 


\section{BIBLIOGRAPHY}




\section{BIBLIOGRAPIY}

\section{Books}

Allmen, Jean-Jacques von. Preaching and Congregation. Richmond, Va.: John Knox Press, 1962.

- Worship: Its Theology and Practice. New York: Oxford University Press, 1965.

Andreason, M. L. The Sabbath. Washington, D.C.: Review and Herald Publishing Association, 1969.

Aulen, Gustaf. Christus Victor. New York: Macmillan Company, 1969.

Bailey, Wilfred M. Awakened Worship. Nashville and New York: Abingdon Press, 1972 .

Baillie, D. M. God Was in Christ. New York: Charles Scribner's Sons, 1948 .

Baker, A. E., ea. William Temple's Teachings. Philadelphia:

Westminster Press, 1951.

Barclay, William. The Revelation of John. 2 vols. Edinburgh: Saint Andrew Press, 1975.

Barth, Karl. The Knowledge of God and the Service of God According to the Teaching of the Reformation. London: Hodder and Stoughton Publistiers, 1949.

Blackwood, Andrew W. The Fine Art of Public Worship. New York:

Abingdon-Cokesbury Press, 1939.

Bligh, John. Galations: A Discussion of St. Paul's Epistle. London:

St. Paul Publications, 1970. 
Bruce, F. F. The Epistle to the Hebrews. Grand Rapids, Mich.: Wm. B. Eerdmans Publishing Company, 1964.

Calvin, John. Institutes of the Christian Religion. 2 vols. Grand Rapids, Mich.: Wm. B. Eerdmans Publishing Company, 1957.

Coffin, Henry Sloane. The Public Worship of God. Philadelphia: The Westminster Press, 1946.

Davis, H. Grady. Why We Worship. Philadelphia: Fortress Press, . 1961.

Fiske, George Walter. The Recovery of Worship. New York: Macmillan Company, 1931.

Garrett, T. S. Christian Worship. London: Oxford University Press, 1963.

Hardin, H. Grady; Quillian, Joseph D.; White, James F. The Celebration of the Gospel: A Study in Christian Worship. Nashville: Abingdon Press, 1964.

Heschel, Abraham Joshua. The Earth Is the Lord's \& the Sabbath. New York: Harper and Row, Fublishers, 1966.

Hoon, Paul Waitman. The Integrity of Worship. Nashville/New York: Abingdon Press, 1971.

Horn, Henry E. Worship in Crisis. Philadelphia: Fortress Press, 1972.

Irving, Roy G., and Zuck, Roy B. Youth and the Church. Chicago: Moody Press, 1968.

Karefa-Smart, John, and Karefa-Smart, Rena. The Halting Kingdom. New York: Friendship Press, 1959. .

Kelley, Alden D. The People of God. Greenwich, Conn.: Seabury Press, 1962.

Kubo, Sakae. God Meets Man. Nashville: Southern Publishing Assn., 3.978 .

LaRondelle, Hans K. Christ Our Righteousness. Mountain View. Calif.: Pacific Press Pub. Assn., 1980. 
Larson, Bruce. Groups That Work. Grand Rapids, Mich.: Zondervan Publishing fiouse, 1967.

Leas, Speed, and Kittlaus, Paul. Church Fights: Managing Conflict in the Local Church. Philadelphia: Westminster Press, 1974.

Leslie, Robert C. Sharing Groups in the Church: An Invitation to Involvement. Nashville: Abingdon Press, 1974.

Lind, Milliard C. Biblical Foundations for Christian Worship. Scottàale, Penn.: Herald Press, 1973.

Mibiti, John S. African Religions and Philosophy. London: Heineman Educational Books, Ltd., 1969.

- ed. Confessing Christ in Different Cultures. Bassey, Switzerland: World Council of Churches Ecumenical Institute, Chateau de Bassey, 1977.

McGavran, Donald A. How Churches Grow. New York: Friendship Press, 1970.

McGavran, Donald A., and Arn, Win. How to Grow a Church. Glendale, Calif.: $\mathrm{G} / \mathrm{C}$ Publ. Regal Books, 1974.

McNutt, William Roy. Worship in the Churches. Philadelphia: Judson Press, 1941.

Milligan, Oswald, B. The Ministry and Worship. London: Oxford University Press, 1941.

Oosterwal, Gottfried. Mission Possible. Nashville: Southern Publishing Assn., 1972.

Otto, Rudolf. The Idea of the Holy. London: Oxford University Press, 1936.

Pannikar, Raymond. Worship and Secular Man. Maryknoll, N.Y.: Orbis Books, 1973.

Paquier, Richard. Dinamics in Worship. Philadelphia: Fortress Fress, 1967.

Pease, Norval F. And Worship Hirn. Nashville: Southern Publishing Assn., 1967. 
Richaràs, Lawrence O. Sixty-nine Ways to Start a Study Group and Keep It Growing. Grand Rapids, Mich.: Zondervan Publishing House, 1973.

Secretariat for Non-Christians. Meeting African Religions. Rome: Libreria Editrice Ancora, n.d.

Segler, Frânklin M. A Theology of Church and Ministry. Nashville: Broadman Press, 1960.

- Christian Worship: Its Theology and Practice. Nashville: Broadman Press, 1967.

Shorter, Aylward. African Christian Theology. Gateshead, England: Geoffrey Chapman Publishers, 1975.

Stott, John R. W. One People. Downers Grove, Ill.: Inter-Varsity Press, 1968.

Tippett, A. R. Verdict Theology in Missionary Theory. Lincoln, Ill.: Lincoln Christian College Press, 1969.

Van Dusen, Henry P. Spirit, Son and Father. New York: Charles Scribner's Sons, 1958.

White, Ellen G. Christian Service. Washington, D.C.: General Conference of Seventh-day Adventists, Home Missionary Department, 1947.

- Counsels to Parents and Teachers. Mountain View, Calif.: Pacific Press Pub. Assn., 1943.

- Desire of Ages. Mourtain View, Calif.: Pacific Press Pub. Assn., 1940 .

- Education. Mountain View, Calif.: Pacific Press Pub. Assn. , 1952 .

- Evangelism. Washington, D.C.: Review and Herald Pub. Assn., 1946

- Prophets ana Kings. Mountain View, Calif.: Pacific Press Pub. Assn., 1917.

- Testimonies for the Church. 9 vols. Mountain View, Calif.: Pacific Press Pub. Assn., 1948. 


\section{Periodicals}

Anderson, R. Allen. "Effective Worship." Ministry, September 1964, p. 48 .

- "The Supremacy of Worship." Ministry, July 1957, pp. 4-6.

- "Work and Worship." Ministry, May 1951, p. 48.

Bietz, A. L. "Our Worship of God." Ministry, October 1958,

Buckwalter, J. A. "Worship Is the Devotion of the Heart to God." Ministry, July 1.957, pp. 26-27.

Dickson, L. K. "Our Worship of God." Ministry, October 1958, pp. $47-54$.

Dunham, Philip W. "The Meaning of Worship." Ministry, April 1968, pp. 17-19.

Fisher, Oliver. "In the Begirning." Ministry, September 1944, pp. $20-23$.

Hyles, Jack. "Ingredients of an Evangelistic Church." Ministry, May 1970, pp. 20-22.

Kavanagh, Aidan. "Religious Life and Worship." Worship. April 1970, pp. 194-200.

LaRondelle, Hans K. "A Profile of the Biblical Doctrine of Salvation." Review, January 5, 1977, pp. 6-7.

Stavenhagen, Werner. "Worshiping God in His Sanctuary." Ministry, May 1955, pp. 40-4).

Tietjen, John H. "Worship and the Life of the Church." Concordia Theological Monthly, March 1972, pp. 144-154.

White, James F. "Characteristics of Effective Christian Worship." Studia Liturgica 8 (n.d.), pp. 195-206. 
Theological Reference Works

Arndt, F., and Ginrich, F. Wilbur. A Greek-English Lexicon of the New Testament and Other Eariy Christian Literature. 1952 ed. Chicago: University of Chicago Press. S.v. "proskuneō."

Feyerabend, Karl. Langenschej.dt Pocket Hebrew Dictionary to the Old Testament. Berlin: McGraw-Hjli Book Company, 1969. S.v. "shachah."

Greeven, Heinrich. "proskuneo." Theological Dictionary of the New Testament. Grand Rapids, Mich.: Wm. B. Eerdmans, 19641976 .

Hatch, Edwin, and Redpath, Henry A. A Concordance to the Septuagint and the Other Greek Versions of the Old Testament. 1954 ed. Graz, Austria: Akademische Druk-U. Verlagsanstallt. S.v. "proskunein."

Horn, Siegfried H. Seventh-day Adventist Bible Dictionary. Washington, D.C.: Review and Herald Publishing Association, 1960. S.v. "worship."

Kittel, Gerhard. "eszhatos." Theological Dictionary of the New Testament. Grand Rapids, Mich.: Wm. B. Eerdmans, $1964-1.976$.

Nichol, Francis D., ed. Seventh-day Adventist Bible Commentary. 7 vois. Washington, D.C. : Review and Herald Publishing Association, 1953-1957.

Strathman, H. "Leitourgeō and leitourgia in the LXX and Hellenistic Judaism." Theological Dictionary of the New Testament. Grand Rapids, Mich.: Wm. B. Eerdmans, 1964-1976.

Young, Robert. Analytical Concordance to the Bibie. 1955 ed. Grand Rapids, Mich.: Wm. B. Eerdmans. S.v. "worship." 


\section{Miscellaneous}

Anderson, R. Allen. "Philosophy and History of Evangelistic and Pastoral Worship." Syllabus. Andrews University Theological Seminary, Berrien Springs, Mich., n.d.

Bietz, Gordon. "Word and Worship in the 17th Century Puritan New England with Emphasis on the Massachusetts Bay Colony." Paper presented at Andrews University Theological Seminary, 1974.

Holmes, C. Raymond. "A Dialogical Evaluation of a Series of Eight Sermons Preached in the Benton Harbor Church of the Seventh-day Adventists from April 6 to June 1, 1974."

D. Min. Project-dissertation, Andrews University, 1975.

"The Liturgical Mission of the Seventh-day Adventist Church." Paper presented at Andrews University Theological Seminary, 8 February 1973.

Sabbath School Department. "The Three Angels' Messages and Worship." Sabbath School Lesson Quarterly. Grantham, Linsc., England: The Stanborough Press, Ltd., 1975. 
VITA 
VITA

NAME: Andre Herman M. Stijnman

DATE and PLACE OF BIRTH: January 31, 1935; Wassenaar, The Netherlands

ADDRESS: $\mathrm{c} / 0$ Adventist Seminary of West Africa

P.M.B. 2.1244, Ikeja, Nigeria

EDUCATION:

Elementary, 1947, Roman Catholic School, Saint Willibrord, Wassenaar, The Netherlards

Secondary, 1952, Roman Catholic High School, Wassenaar, The Netherlands

Theological Seminary, 1962, Oud Zandbergen, Huis ter Heide, The Netrerjands

Bachelor of Arts, j.965, Columbia Union College, Washington, D. C.

Master of Divinity, 1974, Andrews University, Berrien Springs, Mich.

Doctor of Ministry, 1981, Andrews University, Berrien Springs, Mich.

PROFESSIONAL EXPERIENCE:

Ministerial Intern, i i $962-1963$

Licensed Minister, 1965-1968

Secretary, Adventist Youth Society, South Netherlarids

Coníerence, 1968-1970

Ordained Minister, 1970-1976

Bible Teacher, A.S.W.A., Ilishan-Remo, Nigeria, 1976present 